UNIVERSIDADE DE SÃO PAULO

FACULDADE DE ECONOMIA, ADMINISTRAÇÃO E CONTABILIDADE DEPARTAMENTO DE CONTABILIDADE E ATUÁRIA PROGRAMA DE PÓS-GRADUAÇÃO EM CIÊNCIAS CONTÁBEIS

A RELAÇÃO ORIENTADOR-ORIENTANDO E SUAS INFLUÊNCIAS NO PROCESSO DE ELABORAÇÃO DE TESES E DISSERTAÇÕES DOS PROGRAMAS DE PÓS-GRADUAÇÃo EM CONTABILIDADE DA CIDADE DE SÃO PAULO

Geraldo Alemandro Leite Filho Orientador: Prof. Dr. Gilberto de Andrade Martins

SÃo PAULO

2004 
Prof. Dr. Adolpho José Melfi

Reitor da Universidade de São Paulo

Profa. Dra. Maria Tereza Leme Fleury

Diretora da Faculdade de Economia, Administração e Contabilidade

Prof. Dr. Reinaldo Guerreiro

Chefe do Departamento de Contabilidade e Atuária

Prof. Dr. Fábio Frezatti

Coordenador do Programa de Pós-Graduação em Ciências Contábeis 


\title{
A RELAÇÃO ORIENTADOR-ORIENTANDO E SUAS INFLUÊNCIAS NO PROCESSO DE ELABORAÇÃO DE TESES E DISSERTAÇÕES DOS PROGRAMAS DE PÓS-GRADUAÇÃo EM CONTABILIDADE DA CIDADE DE SÃO PAULO
}

\author{
Dissertação apresentada ao Departamento de \\ Contabilidade e Atuária da Faculdade de \\ Economia, Administração e Contabilidade da \\ Universidade de São Paulo como requisito \\ para a obtenção do título de Mestre em \\ Ciências Contábeis.
}

Orientador: Prof. Dr. Gilberto de Andrade Martins

SÃO PAULO

2004 
Dissertação defendida e aprovada no Departamento de Contabilidade e Atuária da Faculdade de Economia, Administração e Contabilidade da Universidade de São Paulo - Programa de Pós-Graduação em Ciências Contábeis, pela seguinte banca examinadora: Prof. Dr. Gilberto de Andrade Martins; Prof. Dr. Miguel Abboud; Profa. Dra. Maria Aparecida Gouvêa.

\section{FICHA CATALOGRÁFICA}

Elaborada pela Seção de Publicações e Divulgação do SBD/FEA/USP

Leite Filho, Geraldo Alemandro

A relação orientador-orientando e suas influências no processo de elaboração de teses e dissertações dos programas de pós-graduação em contabilidade da cidade de São Paulo / Geraldo Alemandro Leite Filho.

-- São Paulo, 2004.

$121 \mathrm{f}$.

Dissertação (Mestrado) - Universidade de São Paulo, 2004 Bibliografia.

1. Contabilidade (Cursos) 2. Pós-graduação 3. Interação professor aluno I. Faculdade de Economia, Administração e Contabilidade da USP. II. Título. 
Agradeço aos colegas da Universidade Estadual de Montes Claros - Unimontes, pelo apoio recebido durante todos estes anos, em especial aos professores Joaquim Eleutério, Carlos Renato, Fernando Coutinho, Gileno, Sandra Reis, Socorro, Eliana, Cida, Geralda Eliana, Fátima Pinho, Marco Aurélio, Juventino, José Nelson e Reinaldo Sandes que não mediram esforços para que eu fizesse este curso de Pós-graduação.

Aos professores do Programa de Pós-graduação em Ciências Contábeis da USP que tanto contribuíram para meu crescimento científico e intelectual, em especial ao Professor Dr. Fábio Frezatti.

Ao Professor Titular Dr. Gilberto de Andrade Martins, pela paciência, atenção e apoio durante o processo de orientação, e pelo rigor, quando foi necessário, o que me fez crescer também como ser humano.

Agradeço ao Prof. Dr. Miguel Abboud e a Prof ${ }^{\mathrm{a}}$. Dra . Maria Aparecida Gouvêa pelas valiosas contribuições durante o exame de qualificação.

Ao professor Dr. Ariovaldo dos Santos, em nome da Fundação Instituto de Pesquisas Contábeis, Atuariais e Financeiras- FIPECAFI, pela concessão da bolsa de mestrado e pelo apoio financeiro para a realização desta pesquisa.

Aos professores e pós-graduandos da USP, PUCSP e FECAP que se disponibilizaram para a concessão das entrevistas desta dissertação.

Aos colegas do curso de mestrado, em especial ao Cláudio, Erasmo, Aládio, Paton, Igor, Amaury, Patrícia, Lílian, Nelma, Márcio, Reinaldo, Flávio e Zé Vicente.

Aos meus familiares, para as minhas duas mães, Zefa e Ruth, e ao meu irmão Igão.

A Leila, esposa e companheira, que me dá forças para continuar a caminhada.

A DEUS, pai, todo poderoso, pelo dom da vida, por acreditar que Ele é o caminho e a verdade.

A todas essas pessoas, o meu muito obrigado! 
“Não se pode ensinar a alguém coisa alguma, pode-se apenas auxiliar a descobrir por si mesmo.”

Galileu

"Embora os mestres e os livros sejam auxiliares, é do esforço próprio que resultam os mais completos e brilhantes resultados.” 


\section{RESUMO}

O presente estudo teve por objetivo diagnosticar, caracterizar e compreender aspectos da relação orientador-orientando e suas influências no processo de produção de teses e dissertações dos programas de pós-graduação stricto sensu em Contabilidade na cidade de São Paulo. Utilizou-se, na abordagem metodológica, pesquisa qualitativa, com coleta de dados por meio de entrevistas semi-estruturadas. As entrevistas foram realizadas com orientadores e orientandos dos programas de pós-graduação em Contabilidade da cidade de São Paulo, na condição de mestres, doutores, mestrandos, doutorandos e professores. Foram pesquisados quinze orientandos e sete orientadores. $\mathrm{Na}$ análise das entrevistas utilizou-se o conceito de categorias de análise, agrupando-se respostas idênticas de sujeitos diferentes. Também foram criados agrupamentos de categorias em concomitância com os objetivos específicos do trabalho. Os resultados indicaram que, na escolha dos orientadores, os orientandos consideraram a congruência de interesses de pesquisa em determinado assunto ou linha de pesquisa. Os principais fatores condicionantes da escolha foram a experiência anterior do orientando com o orientador, a afinidade pessoal e a empatia. Quanto às condições e requisitos para aceitação de alunos para orientação foram encontradas evidências de que os orientadores valorizaram características técnicas dos orientandos, enquanto que os orientandos valorizaram as características afetivas e pessoais para escolha dos orientadores. Com relação aos fatores comportamentais facilitadores do relacionamento, foram identificados o comprometimento e acessibilidade do orientador e orientando, respeito e facilidade de comunicação entre as partes. Quanto aos fatores técnicos e de conhecimento que facilitam a relação, foram enfatizados o conhecimento técnico específico na área de pesquisa, conhecimento e experiência em metodologia de pesquisa, principalmente saber o que se espera de uma dissertação ou tese. Com referência aos encontros de orientação, foram encontrados indícios de encontros assistemáticos, posições autocráticas de orientadores, e relatos de que a quantidade reduzida de encontros não produziu efeitos significativos na qualidade do trabalho o que provocou sentimentos de insegurança, angústia e solidão nos orientandos. Verificou-se também que os encontros surgiram da necessidade emergencial do orientando, o que, conjugado com os fatores falta de tempo e inacessibilidade dos orientadores, provocou aspectos negativos no relacionamento orientador-orientando que influenciaram, de maneira negativa, o processo de construção da dissertação ou tese. Verificou-se que a qualidade do trabalho pode ser resultado do relacionamento construtivo e efetivo entre orientadores e orientandos, quando suas relações afetivas transcendem os aspectos técnicos, quando os orientadores assumem efetivamente seu papel, fazendo leituras críticas e indicando caminhos, numa relação dialética, minimizando sentimentos de isolamento intelectual nos orientandos, e também quando há dedicação e disponibilidade por parte dos orientandos. Como sugestões, indicou-se a utilização de modelos de orientação coletiva; criação de seminários entre orientadores e orientandos para discutir a produção acadêmica na pós-graduação e para apresentar perfis de orientadores e orientandos; utilização de noções de relacionamento interpessoal; e incentivo dos orientadores aos orientandos para que assistam defesas de dissertações e teses, com o objetivo de verificar o que se espera desses trabalhos acadêmicos. 


\begin{abstract}
The present study has had as objective diagnose, characterize and understand aspects about the relationship among supervisor-supervised and theirs influences en the process that produce thesis and dissertations of the postgraduate programs in Accountancy in Sao Paulo City. It was used in the methodological approach qualitative research, with daces collected in semi-structured interviews. The interviews were realized with supervisor and supervised in the postgraduate programs in Accountancy in Sao Paulo City, as masters, doctors, master's degree, doctor's degree and professors. It was researches fifteen supervised and seven supervisors. It was used interviews analyses the concept of categories of analyses, putting together identical answers from different subjects. It was created either group of categories in concomitance with the specific objectives of work. The results pointed to, in the choice of the supervisor, the supervised considered the congruence of interests in do the research in a determined subject or in a line of research. The main factors that condition the choice were the previous experience among supervisor-supervised, personal affinity and empathy. As the conditions and requisites for accept the students to be orientated, was found evidences that the supervisors valued technical characteristics of the supervised, while the supervised valued the personal and affective characteristics to choice the supervisors. In relation to the behaviors factors that make easy the relationship, was identified the compromise and accessibility between supervisor and supervised, respect and facility of communication between them. As the technical factors and knowledge than make easy the relationship, it was given emphases to the specific technical knowledge in the research area, the knowledge and experience in methodology of research, mainly know what is expected in a dissertation or thesis. In reference to the orientates meetings, was found signs of non-systematic meetings, supervisor autocratic positions and relates that the reduced quantity of meetings will not produce significant effects in the work's quality, what provoked feelings of insecurity, anguish an loneliness in the supervised. It was verified too that meetings appeared of the emergent necessity of the supervised, and, together with the factors fault of time and inaccessibility of supervisors, provoked negative aspects in the relationship among supervisor-supervised that influenced, in a negative way, the process of building of the dissertation or thesis. It was verified that the quality of the work shod be result of the constructive and effective relationship among supervisors and supervised, when their relationship transcends the technical aspects, when the supervisors assume effectively their paper, doing critics, reading and indicating ways, in a dialectic relationship, minimize feelings of intellectual isolation in the supervised, an when there are dedication and disposition of the supervised. As suggestions, it was indicated the use of models of collective orientation, upbringing of seminaries between superiors and supervised to discuss the academic production in the postgraduate and to present profiles of supervisors and supervised, use of notions or interpersonal relationship, and supervisors incentive for the supervised to assist defense of dissertations and thesis whit the objective to verify what is expected of a dissertation or thesis.
\end{abstract}


SUMÁRIO

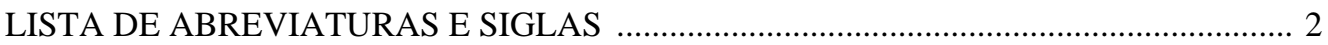

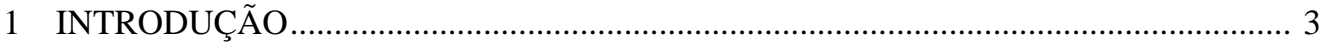

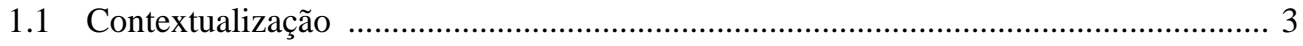

1.2 Antecedentes ao problema ……………………………....................................... 7

1.3 Problema de pesquisa ..................................................................................... 10

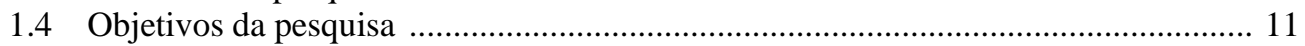

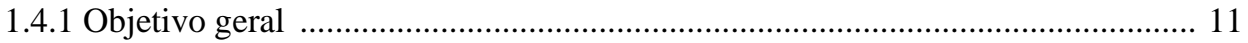

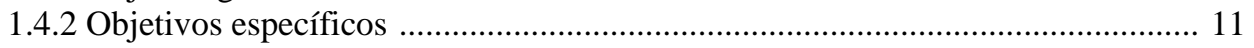

1.5 Justificativas do estudo ................................................................................. 12

1.6 Estrutura do trabalho ........................................................................................ 13

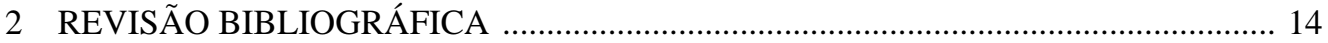

2.1 A evolução da pós-graduação no Brasil ..................................................................... 14

2.2 A pós-graduação na área de Contabilidade ............................................................ 18

2.3 A problemática de orientação de trabalhos acadêmicos ............................................. 21

2.4 Concepções, problemas e funções do orientador e orientando..................................... 38

3 ABORDAGEM METODOLÓGICA ……………..................................................... 49

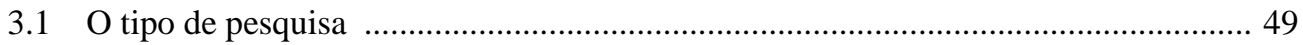

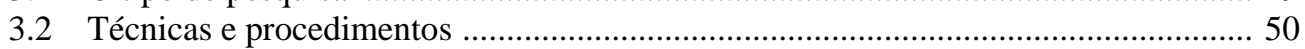

3.3 Sujeitos das entrevistas ................................................................................. 52

3.4 Pré-teste do roteiro de entrevistas ………………………………………………..... 53

3.5 Limitações do estudo ......................................................................................... 54

4 APRESENTAÇÃO E ANÁLISE DOS RESULTADOS …………............................... 56

4.1 Análise das entrevistas ..................................................................................... 56

5 CONCLUSÕES PRELIMINARES E ALGUMAS SUGESTÕES ………………........... 91

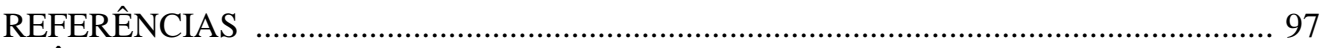

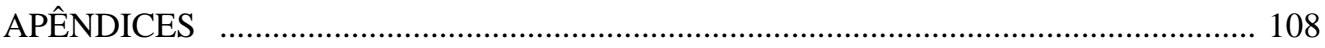




\section{LISTA DE ABREVIATURAS E SIGLAS}

ANPAD: Associação Nacional dos Programas de Pós-graduação em Administração CAPES: Coordenação de Aperfeiçoamento de Pessoal de Nível Superior CFC: Conselho Federal de Contabilidade CFE: Conselho Federal de Educação

FEA/USP: Faculdade de Economia, Administração e Contabilidade da Universidade de São Paulo

FECAP: Fundação Escola de Comércio Álvares Penteado

FGVSP: Fundação Getúlio Vargas de São Paulo

IES: Instituição de Ensino Superior

INEP: Instituto Nacional de Estudos e Pesquisas Educacionais Anísio Teixeira

MEC: Ministério da Educação

NRD6: Núcleo de Referência Docente

PUC/SP: Pontifícia Universidade Católica de São Paulo

UFMG: Universidade Federal de Minas Gerais

UFRJ: Universidade Federal do Rio de Janeiro

UnB: Universidade de Brasília

USP: Universidade de São Paulo 


\section{INTRODUÇÃO}

\subsection{Contextualização}

No Brasil, as atividades de pós-graduação nasceram da urgência e necessidade de titulação dos docentes universitários e sua correspondente qualificação como pesquisadores. Corroboram esta assertiva as pesquisas de Oliveira (1995), Durham (1996), Beiguelman (1998), Reis (1998), Caldas (1998), Fiorin (1999), Martins (2000), Velloso e Velho (2001), Velloso (2002), Martinelli (2002), Gomes (2002) e Cury (2003), nas quais os autores asseveram que a pós-graduação se constitui como o setor mais bem sucedido de todo o sistema educacional brasileiro, concentrando-se nesses cursos quase toda a capacidade de pesquisa nacional, da qual depende a formação de pesquisadores e docentes.

A organização do sistema brasileiro de pós-graduação stricto sensu compreende dois níveis de estudos - o mestrado e o doutorado - que se destinam a criar qualificação especial em determinadas áreas do conhecimento. Nesses cursos, além das atividades didáticas e acadêmicas, exige-se, do candidato ao título de mestre ou doutor, apresentação de trabalho monográfico, elaborado sob a tutela de um professor orientador.

A Resolução 05/83 do CFE - Conselho Federal de Educação -, que regulamenta as atividades da pós-graduação stricto sensu, enuncia que os docentes destes cursos deveriam, além da formação adequada representada pela titulação de doutor, exercer atividade criadora de conhecimentos, demonstrada pela produção de trabalhos originais e de valor comprovado em sua área de atuação. Esses docentes-pesquisadores, quando assumem atividades de orientação de dissertações e teses nos programas de pós-graduação, também deveriam dedicar-se à 
pesquisa e ao ensino em condições de formar, juntamente com os orientandos, ambiente favorável à atividade criadora. A resolução também estabelece que a admissão dos estudantes aos programas de pós-graduação deveria estar condicionada à capacidade de orientação de cada curso, comprovada pela existência de professores orientadores em número suficiente e com disponibilidade de tempo para este fim.

Entretanto, o sistema de pós-graduação, como todo o restante do sistema de ensino brasileiro, vem sofrendo críticas por parte de quantos dele se aproximam ou que sofram seus reflexos. Observa-se descumprimento das diretrizes e resoluções que versam sobre o bom funcionamento dos cursos, havendo relatos, na literatura especializada sobre a pós-graduação, da existência de professores despreparados para atividade de orientação, excesso de alunos orientandos por professores orientadores e carência de orientadores com tempo e disponibilidade para este fim. Como conseqüência deste quadro, os textos oficiais exprimem uma preocupação com a qualidade do produto e com as soluções que vêm sendo tomadas.

Na década de 70, Castro (1979) questionou o problema da orientação nos cursos de pósgraduação, em documento intitulado "Idéias sobre a pós-graduação: a CAPES - Coordenação de Aperfeiçoamento de Pessoal de Nível Superior - e os mecanismos de sinalização", relatando deficiências na atividade de orientação.

Vinte e quatro anos depois, Berndt (2003, p.2) encontrou simetria nas colocações de Castro, observando que, no cotidiano da operação dos programas de pós-graduação, a deficiência mais séria encontra-se no processo de orientação de teses e dissertações, pois em boa medida há professores para ministrar cursos e aulas, e administradores escolares para gerir os programas de pós-graduação, entretanto “[...] orientadores com competência e experiência são 
poucos, diante da demanda contínua por orientação de trabalhos científicos”. Apesar das críticas, verifica-se que a própria CAPES tem utilizado, como um dos seus critérios de avaliação, indicadores quantitativos da produção discente dos programas, como o tempo médio de titulação, quantidade de alunos por professores, percentuais de titulação e desistências, dentre outros. É possível que este tipo de avaliação ocorra em virtude dos seguintes fatores, expressados por Luna (1983, p.4):

O fato de que as teses e dissertações constituem o elemento mais público e publicável dos
programas, na medida em que são, talvez os únicos produtos permanentes, [...] para a maioria dos
programas, pelo menos em princípio, teses e dissertações são colocadas como os momentos em
que o aluno demonstra ou não, a autonomia, a agilidade e criatividade no trabalho escrito,
adquiridas durante a fase de créditos no programa. Esta avaliação da CAPES, assentada em indicadores quantitativos da produção dos programas de pós-graduação, enfatiza a premiação por quantidade e não pela qualidade destes produtos de natureza intelectual. Nesse aspecto, chama-se a atenção para o risco de se ter muita produção com pouca qualidade. Uma prática que poderia ser adotada para superação desta dificuldade seria a submissão do trabalho - enquanto projeto de pesquisa de mestrado ou doutorado - para que uma entidade de fomento realizasse uma avaliação neutra à instituição, com ou sem a liberação de verba (bolsa), para que o pós-graduando pudesse ter uma visão externa do seu projeto. Isto poderia contribuir sobremaneira para aumentar a qualidade dos trabalhos de dissertações e teses nos programas, desta forma, não se atropelariam as disposições e avaliações da CAPES e poder-se-ia ter um ganho substancial na qualidade dos projetos.

Entretanto, observa-se ainda que, por enfatizarem as características quantitativas dos programas de pós-graduação, os critérios de avaliação da CAPES acabam desconsiderando um aspecto que, embora não esteja retratado diretamente nas teses e dissertações, se acredita ser uma das vigas mestras da construção desses trabalhos: a relação orientador-orientando. 
A eficácia da pós-graduação poderia começar a ser estudada dentro da universidade e demonstrada pelo acompanhamento efetivo da atividade profissional do professor orientador e do aluno orientando, através da análise dos fatores que interferem na construção e na qualidade das suas pesquisas. Além do mais, as leituras dos indicadores de qualidade dos programas evidenciam que a fase da elaboração da dissertação ou tese é uma das mais difíceis dos cursos para os alunos. Não obstante, e paradoxalmente, a literatura é escassa no que diz respeito à análise das condições de orientação e do relacionamento entre orientador e orientando, uma vez que não há, no Brasil, a tradição de estudos desta natureza, o que se percebe pela carência de discursos e pesquisas em torno do tema orientação.

Entende-se que o processo de construção do conhecimento em uma área não é uma atividade isolada. Para que isso aconteça, é preciso que ocorra interação entre o sujeito que escreve aluno orientando - e a pessoa, ou grupo de pessoas, da área de conhecimento, que já escreveram e publicaram, os orientadores. Os orientadores são personagens que mantêm relações singulares, intersubjetivas, complexas e ricas em detalhes com os orientandos, sendo que, desta convivência, resultam os trabalhos de pós-graduação - dissertações e teses - que contribuem para a sistematização e consolidação do conhecimento científico em determinada área. Todavia, para que este processo tenha sucesso, faz-se necessário que os orientadores e os orientandos conheçam as suas prerrogativas, constituindo, pelo relacionamento construtivo, espaço propício e efetivo para geração de conhecimentos.

Desta forma, levanta-se a suposição de que, quando estes atores resignam suas funções, podem ocorrer rupturas no relacionamento que acabam por influenciar, de maneira negativa, o processo de construção e a qualidade dos trabalhos da pós-graduação. 
Outro ponto merecedor de atenção é que os programas de pós-graduação enunciam frágeis e vagas descrições sobre a atividade de orientar trabalhos, sem a apresentação de quais seriam as funções, atividades, deveres e condutas de orientadores e orientandos, submetendo estes sujeitos a atuações e atitudes variadas. Em decorrência desta ausência de preceitos, “[...] cada orientador acaba desempenhando suas funções à sua maneira, como lhe convém, guiando-se por experiências passadas, ou por justificativas carregadas de juízos de valor [...]”, mostrando despreparo para as atividades de orientação, conforme observou Martins (1997, p.58).

Parte-se da premissa de que um dos pontos críticos, responsável por fracassos e sucessos dos alunos na pós-graduação, seja a atividade de orientação. Investigações de Bianchetti e Machado (2002) apontaram disfunções fundamentais sobre os sujeitos envolvidos na orientação, relacionando os obstáculos e dificuldades da orientação com a capacidade de escrita e construção dos trabalhos dos orientandos, deixando fortes evidências de quanto a atividade de orientação qualifica os orientandos para a autoria. Diante do exposto, observouse que a orientação pode ser uma tarefa crucial para a geração de conhecimentos científicos novos e, como é pouco estudada, merece ser pesquisada.

\subsection{Antecedentes ao problema}

A investigação de aspectos internos dos programas de pós-graduação, como problemas de produção de dissertações e teses, bem como seus fatores inibidores e facilitadores, dentre outros, é discutida em vários trabalhos e pesquisas, destacando-se, em Vasconcellos (1981), os problemas da produção de dissertações de mestrado na área de Administração, as suas 
barreiras e as possíveis soluções; em Correa (1984), os fatores relevantes na escolha de um tema de pesquisa e a influência do orientador nesta escolha; em Fernandes et al. (1993), pesquisa sobre elementos inibidores e facilitadores de uma dissertação de mestrado; em Sauaia e Oliveira (1994), estudo sobre as percepções dos alunos sobre o programa de pósgraduação em Administração da USP; em Souza (1994), pesquisa sobre os pressupostos metodológicos e a pós-graduação em Administração; em Santos (1998), a formação e treinamento dos administradores, estudando a produção das dissertações no curso de mestrado da UFMG; em Godoy et al.(2000), estudo sobre as concepções e expectativas dos alunos sobre os programas de mestrado em Administração; em Freitas e Zawislak (2003), questionamentos sobre o processo de mestrado em Administração e, conseqüentemente, o sucesso ou o fracasso dos alunos orientandos. Embora a relação orientador-orientando não seja o foco específico destes estudos, de certa forma, discutem assuntos que estão associados a esta temática.

Estudos mais específicos sobre o problema da orientação constam em Moses (1984), Rudd (1984), Knigth e Zuber-Skerritt (1986), nos quais os pesquisadores enfocaram a significância da orientação inadequada e sua relação com o fracasso dos pós-graduandos na condução e conclusão das suas pesquisas; em Reis (2003) e Madsen (1992), estudos sobre as causas dos estudantes de pós-graduação não completarem as suas dissertações; em Cryer (2003) e Piccinin (2003), os problemas de orientação em programas de doutoramento; em Frame e Allen (2002), pesquisa sobre propostas e abordagens flexíveis em programas de doutoramento para melhorar a prática da orientação; em Loui (2003), pesquisa sobre as escolhas de orientadores de teses e dissertações, apontando, como um dos mais comuns problemas da pósgraduação nas Ciências Humanas e Sociais, o contato insuficiente entre orientadores e orientandos; em Santos Filho e Carvalho (1991), Rodrigues Jr. et al. (1993), Lehmann e 
Rodrigues Jr. (2001), estudos sobre as interações entre orientadores e orientandos com base em incidentes críticos; em Dong (1998), as interações entre os orientadores de teses e dissertações e seus orientandos com relação às formas de produção textual; em Martins (1997) e Berndt (2003), pesquisas sobre a relação entre orientador e orientando na elaboração de trabalhos científicos e a questão da orientação na pós-graduação em Administração.

No que concerne a estudos divulgados em dissertações de mestrado e teses de doutorado, apresenta-se, em Pinto (1980), um estudo sobre a análise do comportamento de pesquisa dos estudantes de pós-graduação em Psicologia, apontando o relacionamento entre o orientador e orientando no programa de pós-graduação em Psicologia da USP; em Luna (1983), a análise das dificuldades na elaboração de teses e dissertações a partir de prováveis contingências que controlam esta atividade, sugerindo alterações nos modelos de orientação; em Sanches (1992), pesquisa sobre o processo de elaboração de dissertações e teses dos alunos dos programas de estudos em Psicologia Social e Educação da PUCSP; em Castro (1993), estudo psicanalítico e das teorias do discurso, retratando o orientando pré-cedido pelo retrato do orientador; em Carvalho (1994), estudo das considerações psicanalíticas sobre o processo de elaboração de uma dissertação de mestrado e as relações entre orientador e orientando; em Martins (1994), pesquisa sobre a construção do conhecimento nos programas de pós-graduação em Administração, com destacada atenção para o problema da orientação desses cursos; em Gomes (1995), um estudo sobre aspectos de orientação lingüística e gramatical na redação de teses e dissertações produzidas no programa de mestrado e doutorado em Administração da FGV/SP, no período de 1989 a 1993; em Santos (1997), uma pesquisa sobre a análise institucional das relações entre orientadores e orientandos de pesquisa em enfermagem na UFRJ; e, em Lehmann (1999), um estudo sobre os fatores que intermediam as relações orientador-orientando durante a dissertação de mestrado na Universidade Católica de Brasília. 
Citando livros, destacam-se os trabalhos de: Bianchetti (1997), no qual se discute a questão da produção textual nos programas de pós-graduação; Bianchetti e Machado (2002), sobre a questão da orientação e os seus impactos no direcionamento dos alunos dos programas de pós-graduação; e em Severino (2002), que apresenta considerações acerca dos programas de pós-graduação e aspectos do relacionamento orientador-orientando.

Apesar da contribuição destes estudos nas diversas áreas do conhecimento, nota-se carência de pesquisas dessa natureza sobre os programas de pós-graduação em Contabilidade, de forma que se possa entender o ambiente de orientação e as suas conseqüências na produção e na qualidade dos trabalhos intelectuais destes programas.

\subsection{Problema de pesquisa}

Os comentários apresentados anteriormente apontam a necessidade de investigação dos aspectos relativos ao ambiente de orientação nos programas de pós-graduação em Contabilidade. Considerando-se o interesse em um melhor conhecimento da problemática da relação entre os orientadores e orientandos nesses programas, feitas as delimitações julgadas necessárias, apresenta-se a questão de pesquisa que se pretende discutir, averiguar e responder por meio deste estudo:

Quais são os principais aspectos da relação orientador-orientando que influenciam o processo de produção de teses e dissertações dos programas de pós-graduação stricto sensu em Contabilidade da cidade de São Paulo? 


\subsection{Objetivos da pesquisa}

\subsubsection{Objetivo geral}

Em consonância com a questão de pesquisa, foi proposto o seguinte objetivo geral:

O objetivo geral deste trabalho foi diagnosticar, caracterizar e compreender aspectos da relação orientador-orientando e suas influências no processo de produção de teses e dissertações dos programas de pós-graduação em Contabilidade da cidade de São Paulo.

\subsubsection{Objetivos específicos}

Em concomitância com o objetivo geral da pesquisa, apresentam-se os seguintes objetivos específicos:

- Identificação e análise de quais aspectos levaram os alunos orientandos a escolherem os seus professores orientadores e os aspectos que levaram os professores orientadores a aceitarem os alunos orientandos;

- Levantamento e análise de como se deram os encontros de orientação;

- Identificação, descrição e análise de fatores comportamentais, técnicos e de conhecimento que permeiam a relação orientador-orientando;

- Verificação, com base no relato dos sujeitos envolvidos, da associação existente entre a relação orientador-orientando e indicadores de qualidade das dissertações/teses dos respectivos programas. 


\subsection{Justificativas do estudo}

A opção por um trabalho desta natureza decorre da importância de se discutir e investigar aspectos que teriam ligação com a construção do conhecimento na área de Contabilidade. Observou-se que não há uma tradição, no Brasil, mais especificamente na área de Contabilidade, de estudos sobre a temática de orientação, condições de produção de teses e dissertações e relacionamento entre orientador e orientando, tendo esta pesquisa a característica de abordar um tema inédito, que necessita de indagação e entendimento.

O estudo também se justificou por tentar sinalizar a importância da temática orientação, pois acredita-se que os resultados avaliativos das condições de orientação, do esforço dos orientadores e orientandos na construção do conhecimento em Contabilidade, poderiam contribuir para o entendimento, minimização e solução dos problemas de relacionamento entre estes sujeitos. Desta forma, a concepção de estudos sobre a relação orientadororientando como um objeto complexo remete à necessidade de sua compreensão e discussão, constituindo-se como um interessante campo de pesquisa.

Outro ponto que justificou este estudo foi o crescimento e expansão dos cursos de pósgraduação na área de Contabilidade e o conseqüente aumento da demanda de orientação, não tendo sido encontradas evidências de sistematização da atividade de orientação, bem como sobre as prerrogativas dos sujeitos envolvidos nesse objeto. Entende-se que a melhoria da qualidade dos trabalhos de pós-graduação não dependeria somente de ações externas aos programas de pós-graduação ou de diretrizes revogadas pelos órgãos competentes. Faz-se necessária a conscientização, seriedade, comprometimento e dedicação dos professores 
orientadores e alunos orientandos, pois acredita-se que o sucesso e a qualidade de uma tese ou dissertação podem ser conseqüência do relacionamento construtivo e da plena consonância desses sujeitos em torno de uma idêntica finalidade e de uma mesma produção de natureza intelectual.

\subsection{Estrutura do trabalho}

Este estudo está estruturado em cinco capítulos, assim distribuídos: o primeiro capítulo, além da contextualização e dos antecedentes do problema, enfoca o problema de pesquisa, os objetivos que nortearam a pesquisa e as justificativas. O segundo capítulo trata da revisão bibliográfica do conteúdo teórico utilizado. Já o terceiro capítulo aborda os caminhos metodológicos utilizados para a condução do estudo. O quarto capítulo trata da apresentação e da análise dos resultados da pesquisa empírica. No quinto capítulo, apresentam-se as conclusões preliminares e algumas sugestões. Em seguida, constam as referências bibliográficas consultadas e os apêndices.

O próximo capítulo retratará a revisão da bibliografia utilizada como referencial para sustentar teoricamente o estudo. 


\section{REVISÃO BIBLIOGRÁFICA}

Este capítulo objetiva dar sustentação teórica à pesquisa, apresentando dados sobre a evolução da pós-graduação stricto sensu no Brasil, destacando a área de Contabilidade. Além disso, expõe e discute a posição de diversos autores sobre a questão da orientação de trabalhos acadêmicos de pós-graduação, concepções da orientação, papéis, direitos e deveres de orientadores e orientandos. Apresenta também sugestões para a superação de problemas ligados com a orientação no relacionamento orientador-orientando.

\subsection{A evolução da pós-graduação no Brasil}

A pós-graduação no Brasil foi institucionalizada a partir de 1965, mediante o Parecer $n^{\circ} 977$ do extinto Conselho Federal de Educação do Ministério da Educação. Neste período, com o reordenamento dos rumos sócio-políticos no Brasil, houve um grande interesse em fomentar o desenvolvimento do sistema nacional de pós-graduação, principalmente em nível federal, com a alocação de recursos financeiros e humanos para este setor, já que se tornava evidente que o ensino de graduação era insuficiente para atender às necessidades de profissionais qualificados demandados pelo sistema econômico (MARTINELLI, 2002; MARTINS, 2000). Este parecer estabeleceu os seguintes requisitos mínimos para a obtenção do título de mestre e doutor, descritos por Martinelli (2002, p.5):

(1) Cursos de duração mínima de dois anos, (2) constituídos de estudos de matérias da área de concentração e de domínio conexo, (3) uma tese para o doutorado e uma dissertação para o mestrado, (4) exames parciais e gerais, e (5) aprovação em provas que verifiquem capacidade de leitura em duas línguas estrangeiras.

Beiguelman (1998) e Martinelli (2002) observam que o sistema de pós-graduação brasileiro foi organizado em dois níveis de formação sucessivos, equivalentes ao Master Degree e ao 
Ph. Doctor do modelo norte-americano. Assim foi feito e o sistema vem se expandindo e se consolidando, apesar de críticas por parte da comunidade acadêmica relativas, sobretudo, a questões de financiamento (REIS, 1998), e outras mais abrangentes, envolvendo formatos e processo de avaliação dos cursos (CALDAS, 1998). Apesar disto, existe uma relativa unanimidade quanto ao êxito do sistema de pós-graduação, cujo exemplo tem sido seguido por outros países em desenvolvimento (VELLOSO; VELHO, 2001).

Velloso (2002) ressalta que, na década de setenta, a pós-graduação stricto sensu presenciou um notável crescimento em todas as áreas, bem como o aparecimento da maioria dos programas e cursos de pós-graduação. Nos anos 1990, este crescimento se acentuou, registrando-se, no ano de 2000, um intenso aumento no número de vagas oferecidas, de resultados de pesquisa publicados e, principalmente, de titulações de doutorado e mestrado (100\% e $150 \%$, respectivamente, comparando-se os dados de 2000 em relação ao ano de 1995).

As causas para este crescimento estão relacionadas ao mercado de trabalho universitário, que tem recebido impulsos para expansão das políticas para o ensino superior, a novas exigências legais para o credenciamento de universidades, à titulação do corpo docente e à institucionalização da pesquisa (VELLOSO, 2002; VELLOSO; VELHO, 2001).

Martins (2000) observou que o sistema de pós-graduação permanece como o setor mais bem sucedido do ensino brasileiro, porque contou com um planejamento adequado para orientar seu crescimento, sustentado numa contínua política de financiamento pelos órgãos de fomento e amparada por um eficiente sistema de avaliação e credenciamento dos seus cursos. Para Beiguelman (1998), este reconhecimento acadêmico da pós-graduação tem estimulado 
estrategicamente a manutenção de uma política sistemática de apoio e de melhoria constante para esses cursos.

Martinelli (2002), analisando a evolução dos programas, verificou que, em 1966, existiam apenas 33 cursos de mestrado e 33 de doutorado, sendo que as áreas de Ciências Exatas e Engenharia constituíam cerca de 50\% do total. Segundo a autora, na década de 1970 e 80, houve verdadeira explosão de cursos, principalmente ligados à área de Ciências Humanas e Sociais, explicada pelo rápido crescimento econômico que afetou tanto o mercado de trabalho como o sistema educacional, uma vez que este desenvolvimento sócio-econômico requereu inovação técnica e científica. No início da década de 90, havia 964 cursos de mestrado e 450 de doutorado, confirmando o crescimento e expansão do sistema de pós-graduação nacional.

Para contextualizar a discussão, o gráfico a seguir apresenta a evolução dos cursos de pósgraduação no Brasil (mestrado e doutorado) de 1966 até 2003:

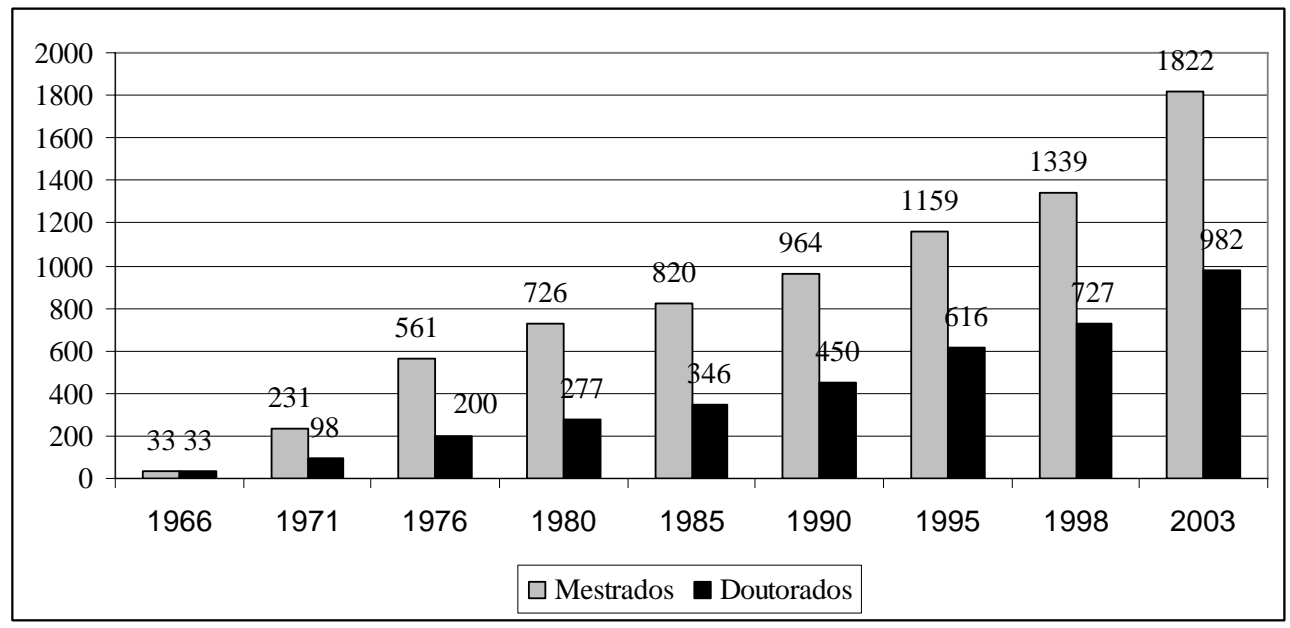

Gráfico 1 - Evolução dos cursos de mestrado e doutorado no Brasil - 1966 a 2003. Fonte: CAPES/MEC (2003). 
Analisando-se os dados do gráfico 1, observa-se que, de 1980 para 1990, houve um crescimento de $33 \%$ na quantidade de mestrados e de $62 \%$ na quantidade de doutorados. Comparando-se 2003 com 1990, verifica-se um crescimento de 89\% na quantidade de mestrados e de $118 \%$ na quantidade de doutorados, evidenciando a expansão do sistema nacional de pós-graduação. No ano de 2003, o Brasil contava com 1.708 programas de mestrado acadêmico, 114 mestrados profissionais e 982 doutorados, distribuídos pelas diversas áreas, conforme a Tabela 1:

Tabela 1 - Quantidade de cursos de mestrado e doutorado por área - Brasil (2003)

\begin{tabular}{|l|c|c|c|c|c|c|}
\hline \multirow{2}{*}{ Grande área } & \multicolumn{2}{c|}{$\begin{array}{c}\text { Mestrado } \\
\text { Acadêmico }\end{array}$} & \multicolumn{2}{c|}{$\begin{array}{c}\text { Mestrado } \\
\text { Profissional }\end{array}$} & \multicolumn{2}{c|}{ Doutorado } \\
\cline { 2 - 7 } & Quant. & $\mathbf{\%}$ & Quant. & $\mathbf{\%}$ & Quant. & \% \\
\hline Ciências Agrárias & 194 & 11,4 & 1 & 0,9 & 112 & 11,4 \\
\hline Ciências Biológicas & 165 & 9,7 & 5 & 4,4 & 125 & 12,7 \\
\hline Ciências da Saúde & 331 & 19,4 & 24 & 21,1 & 228 & 23,2 \\
\hline Ciências exatas e da terra & 195 & 11,4 & 8 & 7,0 & 122 & 12,4 \\
\hline Ciências humanas & 256 & 15,0 & 6 & 5,3 & 132 & 13,4 \\
\hline Ciências sociais aplicadas & 189 & 11,1 & 24 & 21,1 & 74 & 7,5 \\
\hline Engenharias & 191 & 11,2 & 22 & 19,3 & 104 & 10,6 \\
\hline Lingüística, letras e artes & 99 & 5,8 & 1 & 0,9 & 58 & 5,9 \\
\hline Ensino & 10 & 0,6 & 4 & 3,5 & 3 & 0,3 \\
\hline Multidisciplinar & 78 & 4,6 & 19 & 16,7 & 24 & 2,4 \\
\hline Total & $\mathbf{1 . 7 0 8}$ & $\mathbf{1 0 0 , 0}$ & $\mathbf{1 1 4}$ & $\mathbf{1 0 0 , 0}$ & $\mathbf{9 8 2}$ & $\mathbf{1 0 0 , 0}$ \\
\hline
\end{tabular}

FONTE: CAPES/MEC (2003)

Ao analisar-se a Tabela 1, percebe-se que, tanto no mestrado quanto no doutorado, a maior quantidade de programas situa-se nas áreas de Ciências da Saúde (19\% dos mestrados acadêmicos e 23\% dos doutorados) e Ciências Humanas (15\% dos mestrados acadêmicos e $13 \%$ dos doutorados).

A seguir, discutir-se-á a pós-graduação na área de Contabilidade, foco principal deste estudo, comentando-se dados da área de Ciências Sociais Aplicadas. 


\subsection{A pós-graduação na área de Contabilidade}

Analisando-se os dados da Tabela 1, nota-se que a área de Ciências Sociais Aplicadas tem a maior participação nos programas de mestrados profissionais em comparação com as demais áreas. Entretanto, tal situação é diferente para os programas de mestrado acadêmico, com 11\% do total de cursos, e mais ainda para os programas de doutorado, significando $7,5 \%$ do total de cursos. Com vistas a contextualizar os programas de pós-graduação em Contabilidade no cenário nacional, a Tabela 2 apresenta a distribuição desses cursos dentro da área de Ciências Sociais Aplicadas:

Tabela 2 - Quantidade de cursos - Ciências Sociais Aplicadas - Brasil (2003)

\begin{tabular}{|l|c|c|c|c|c|c|}
\hline \multirow{2}{*}{$\begin{array}{l}\text { Ciências Sociais Aplicadas } \\
\text { Cursos }\end{array}$} & \multicolumn{2}{|c|}{$\begin{array}{c}\text { Mestrado } \\
\text { Acadêmico }\end{array}$} & \multicolumn{2}{c|}{$\begin{array}{c}\text { Mestrado } \\
\text { Profissional }\end{array}$} & \multicolumn{2}{c|}{ Doutorado } \\
\cline { 2 - 7 } & Quant. & $\mathbf{\%}$ & Quant. & $\mathbf{\%}$ & Quant. & $\mathbf{\%}$ \\
\hline Administração & 30 & 15,9 & 14 & 58,3 & 11 & 14,9 \\
\hline Arquitetura e Urbanismo & 14 & 7,4 & 0 & 0,0 & 6 & 8,1 \\
\hline Ciências da Informação & 7 & 3,7 & 0 & 0,0 & 3 & 4,1 \\
\hline Comunicação & 19 & 10,1 & 0 & 0,0 & 11 & 14,9 \\
\hline Contabilidade & $\mathbf{8}$ & $\mathbf{4 , 2}$ & $\mathbf{1}$ & $\mathbf{4 , 2}$ & $\mathbf{1}$ & $\mathbf{1 , 4}$ \\
\hline Demografia & 2 & 1,1 & 0 & 0,0 & 2 & 2,7 \\
\hline Desenho Industrial & 3 & 1,6 & 0 & 0,0 & 1 & 1,4 \\
\hline Direito & 46 & 24,3 & 0 & 0,0 & 14 & 18,9 \\
\hline Economia & 32 & 16,9 & 8 & 33,3 & 15 & 20,3 \\
\hline Planejamento urbano & 8 & 4,2 & 1 & 4,2 & 2 & 2,7 \\
\hline Serviço Social & 17 & 9,0 & 0 & 0,0 & 8 & 10,8 \\
\hline Turismo & 3 & 1,6 & 0 & 0,0 & 0 & 0,0 \\
\hline Total & $\mathbf{1 8 9}$ & $\mathbf{1 0 0 , 0}$ & $\mathbf{2 4}$ & $\mathbf{1 0 0 , 0}$ & $\mathbf{7 4}$ & $\mathbf{1 0 0 , 0}$ \\
\hline
\end{tabular}

FONTE: CAPES/MEC (2003)

Verifica-se uma situação preocupante quando se compara o número de programas de pósgraduação em Contabilidade com as demais áreas dentro das Ciências Sociais Aplicadas. Observa-se que os programas de mestrado acadêmico em Contabilidade participam com 4,2\% do total dos programas, $4,2 \%$ dos mestrados profissionais e apenas $1,4 \%$ do total dos doutorados. A quantidade de programas de pós-graduação em Contabilidade só supera, no 
mestrado, programas recentemente criados e implementados, como Ciências da Informação, Demografia, Turismo e Desenho Industrial. Contudo, no doutorado, a Contabilidade só supera a área de Turismo em termos quantitativos. Apesar de existirem programas de mestrado desde a década de 1970, percebe-se que o número de programas na área de Contabilidade ainda é muito baixo, se comparado com áreas correlatas como Administração, Direito e Economia.

Por outro lado, o curso de graduação em Contabilidade foi, durante a década de 1990, um dos dez maiores do Brasil, com base no número de alunos ingressantes, matriculados e concluintes, de acordo com informações do INEP - Instituto Nacional de Estudos e Pesquisas Educacionais Anísio Teixeira. Destaca-se, também, o rápido crescimento do número de cursos: em 1999 havia 458 cursos de graduação em Ciências Contábeis; ao final de 2000 mais 51 novos cursos haviam sido autorizados; e, atualmente, são mais de 600 (seiscentos) cursos autorizados na área contábil, segundo dados coletados no CFC - Conselho Federal de Contabilidade.

Verifica-se que este crescimento da graduação não ocorreu, em termos quantitativos, nos programas de pós-graduação em Contabilidade. Ocorre que o Brasil possuía, em 1999, apenas quatro cursos de mestrado e apenas um de doutorado em Contabilidade, devidamente autorizados pela CAPES. Ademais, estes cursos estavam concentrados, em sua quase totalidade, na região Sudeste. O reduzido número de cursos de pós-graduação fazia com que, naquele ano, existissem no Brasil apenas 90 doutores e 450 mestres, aproximadamente. Os dados apresentados evidenciam que, com o número de cursos de pós-graduação existentes até 1999, dificilmente seriam alcançados os almejados níveis de qualidade do ensino e da pesquisa na área de Contabilidade. 
Apesar do aumento do número de programas em Contabilidade de 1999 para 2003, ressalta-se que a incipiente infra-estrutura de pós-graduação nessa área restringia as chances das IES (Instituições de Ensino Superior) brasileiras de alcançarem, na área de Ciências Sociais Aplicadas, os índices de qualificação estabelecidos na Lei de Diretrizes e Bases da Educação Nacional, se comparados com Direito (46 mestrados e 14 doutorados), Economia (32 mestrados e 15 doutorados) e Administração (30 mestrados e 11 doutorados), conforme dados apresentados na Tabela 2.

Pelos dados de 2003, apresentados na Tabela 2, no Brasil existiam nove programas de mestrado (oito acadêmicos e um profissionalizante) e apenas um doutorado em Contabilidade que estão devidamente reconhecidos e aprovados pela CAPES, continuando ainda, a sua grande maioria, localizada na região Sudeste (63\%, 5 dos 8 programas). Os programas acadêmicos são: Programa de Pós-Graduação em Controladoria e Contabilidade da Universidade de São Paulo (USP), Programa de Pós-Graduação em Ciências Contábeis e Atuária da Pontifícia Universidade Católica de São Paulo (PUCSP), Programa de PósGraduação em Controladoria e Contabilidade Estratégica (FECAP), Programa de PósGraduação em Ciências Contábeis da Universidade Estadual do Rio de Janeiro (UERJ), Programa de Pós-Graduação em Ciências Contábeis da Universidade Federal do Rio de Janeiro (UFRJ), Programa de Pós-Graduação em Ciências Contábeis da Fundação Visconde de Cairú (FVC), Programa de Pós-Graduação em Ciências Contábeis da Universidade do Vale do Rio dos Sinos (UNISINOS), Programa de Pós-Graduação em Ciências Contábeis da Universidade de Brasília (UnB). O programa de Mestrado Profissionalizante é da Universidade Federal do Ceará (UFC). 
Além das considerações anteriormente citadas a respeito da evolução da pós-graduação no Brasil e da quantidade e distribuição destes cursos na área de Contabilidade, chama-se a atenção também para aspectos internos do ambiente dos cursos de pós-graduação. Considerando-se os objetivos assumidos neste trabalho, apresentar-se-á, no subitem a seguir, a contribuição de diversos autores sobre a questão da orientação, dos papéis do orientador e orientando na pós-graduação e da relação orientador-orientando.

\subsection{A problemática de orientação de trabalhos acadêmicos}

Conforme os dados apresentados sobre a evolução da pós-graduação no Brasil (Gráfico 1 e Tabela 1), é inquestionável o crescimento da produção científica na área de Contabilidade nos últimos anos. Multiplicaram-se os programas de pós-graduação stricto sensu, bem como elevaram-se as ofertas de cursos de especialização. Desta maneira, cresceu também, de forma extraordinária, a publicação de artigos científicos, monografias, dissertações e teses, evidenciando uma atenção especial para estes trabalhos. Martins (1997, p.57) observou que “[...] neste processo quase frenético, muitos professores desses cursos, espontaneamente ou forçosamente, agregaram às suas funções docentes o papel de orientadores de trabalhos acadêmicos.”

Para Zilbermann (2002), esta expansão dos cursos de pós-graduação no Brasil, a partir dos anos 1970, criou uma situação nova no quadro do ensino brasileiro, que é a relação acadêmica entre o professor orientador e o aluno orientando de um projeto de dissertação de mestrado ou tese de doutorado. A autora assevera que tal relação foi delineada com a exigência de um trabalho final escrito, redigido pelo aluno, sob a tutela e responsabilidade de um professor credenciado, e ainda determinou o aparecimento de uma ligação mais pessoal, horizontal e 
profissional entre o orientador e o orientando. Com relação a esta ligação interpessoal, a autora relata que

[...] o processo interpessoal de aprendizagem mútua e contínua representado pela relação orientador-orientando é, provavelmente, a principal novidade da educação e da ciência brasileira nos últimos trinta anos do século XX. Fruto da implantação e expansão dos cursos de pósgraduação, essa aventura compartilhada constitui sua criação mais importante, embora não seja original. De sua conservação depende a manutenção dos próprios estudos pós-graduados, já que é nesse lugar que se constitui a produção de conhecimento por excelência, razão de ser do ensino, da pesquisa e da docência. (ZILBERMANN, 2002, p.334)

Presume-se que a orientação de trabalhos de pós-graduação surja da existência de um candidato (aluno) ao título de mestre ou doutor, motivado pelos seus interesses de pesquisa, e um professor orientador habilitado na área e disposto a interpretar as exigências, anseios e objetivos deste aluno orientando. Em princípio, tais observações parecem simples e óbvias, entretanto, Eco (1998) aponta que a não adequação do professor orientador aos anseios do orientado é um dos fatores que contribuem para o insucesso do orientando na finalização do trabalho monográfico, como segue:

Com efeito, há candidatos que, por razões de simpatia ou preguiça, querem fazer com o docente da matéria A uma tese que em verdade é da matéria B. O docente aceita a orientação (por simpatia, vaidade ou desatenção) e depois não se vê a altura de seguir a tese. (ECO, 1998, p.6)

Estudos de Santos Filho e Carvalho (1991, p.74), Martins (1997, p.57), Knigth e ZuberSkerrit (1986) dissertam que a agregação da função de orientador pelos professores, desprovida de preparo, orientação e treinamento, parece estar baseada em duas pressuposições básicas: a primeira, de que os orientadores são academicamente qualificados na área de pesquisa do estudante e, a segunda, de que, tendo o orientador concluído com sucesso um projeto de pesquisa, está apto a ensinar habilidades de pesquisa e de redação de relatórios, tais como teses e dissertações.

Publicações e pesquisas de Moses (1984), Rudd (1984), Luna (1983), Carvalho (1994), Lehmann e Rodrigues Jr. (2001), Rodrigues Jr. et al. (1993), Berndt (2003), Madsen (1992), 
Reis (2003), Piccinin (2003), Cunha (1991), Bianchetti e Machado (2002), Warde (1993), Haguette (1994), Costa (2004) e Castro (2002) têm apontado evidências de que as pressuposições anteriormente citadas nem sempre têm fundamento e não se aplicam a todos os orientadores. Tais estudos citam a orientação inadequada como um fator muito significativo, relacionado ao fracasso dos pós-graduandos na conclusão das suas pesquisas.

Santos Filho e Carvalho (1991) observaram que o pouco contato do estudante com o seu orientador ou a ineficácia deste contato pode, até mesmo, dar ao estudante a impressão de que seu fracasso em avançar e concluir sua pesquisa seja fruto de sua incompetência. Segundo Martins (1997), “[...] isto, às vezes, pode estar relacionado a problemas emocionais e psicológicos resultantes do isolamento intelectual, da insegurança quanto aos padrões exigidos e da falta de confiança em ser capaz de concluir seu trabalho no tempo e nos padrões estipulados.”

Esses autores (1991) sugeriram que problemas desta natureza estariam relacionados com o considerável grau de evasão dos pós-graduandos e o baixo rendimento da maioria dos programas de pós-graduação no país. Segundo os autores, a evasão ou insucesso em concluir sua dissertação ou tese representa um custo muito alto para o estudante, para o orientador, para a instituição, para o sistema educacional e para a sociedade, em termos de investimento em tempo, em recursos financeiros e compromisso pessoal, institucional e social.

Nesse contexto, Saviani (2002, p.159) evidencia que

O ponto nodal do sistema de pós-graduação reside na orientação. É, com efeito, através do processo de orientação, que o aprendiz de pesquisador pode dar, com segurança, os passos necessários ao domínio desta difícil prática, que é a pesquisa, de modo a ganhar, ao cabo do processo formativo, a indispensável autonomia intelectual que lhe permitirá formular projetos próprios, de caráter original [...] 
Na mesma linha de Saviani, Haguette (1994, p.60) chamou a atenção para dois problemas que repercutem no processo de geração de conhecimentos nos programas de pós-graduação: a incompetência metodológica do orientador de dissertações e teses e seu relacionamento com os orientandos. A autora observou que o domínio dos meandros metodológicos exerce uma influência primordial sobre a forma como o orientador se conduz na relação com o orientando, destacando que a "[...] competência principal do mestre que a universidade deveria formar é a competência de pesquisador”, ainda ressaltando que:

\begin{abstract}
No que se concerne ao desempenho da atividade de orientação - sobretudo nas dissertações de mestrado em que o novo ingresso, na sua grande maioria, é admitido sem o preparo mínimo sequer para elaborar um projeto de investigação de qualidade regular - o aluno fica à mercê da competência ou incompetência do orientador. (HAGUETTE, 1994, P.60).
\end{abstract}

Nesta linha, o estudo de Martins (1994, p.64-89) concluiu que 13\% dos trabalhos do mestrado e doutorado na área de Administração do estado de São Paulo apresentaram problemas metodológicos que refletiram, na opinião do pesquisador, "fraqueza intelectual dos autores e dos orientadores”, confirmando as observações de Haguette. Uma constatação do pesquisador que valida esta afirmação foi a descoberta do mesmo formato ou padrão dos trabalhos produzidos por orientandos de um mesmo orientador, relatando que “[...] repete-se boa parte da bibliografia, algumas justificativas metodológicas e o figurino se mantém constante”, depreendendo-se que o orientador passa a mesma receita para seus orientandos, independente do assunto ou tema que se pretenda investigar, denotando indícios de incompetência metodológica e descaso com a atividade de orientação, refletidos nos trabalhos de pósgraduação.

Rodrigues Jr. et al. (1993) estudaram e identificaram circunstâncias que poderiam intervir no processo de elaboração de uma dissertação de mestrado, centrando-se nas figuras do orientador e do orientando. O estudo revelou que os orientadores e orientandos pesquisados 
atribuíram dificuldades de condução da dissertação a aspectos de conteúdo e ao gerenciamento do processo de orientação. Quanto à relação orientador-orientando, os sujeitos mencionaram que a indisponibilidade dos orientadores, a liberdade excessiva que o orientando teve para desenvolver o trabalho, envolvimento insuficiente com as atividades do mestrado, a falta de empenho e motivação dos orientandos e a falta de contatos sistemáticos com os orientadores foram fatores que estavam relacionados à não conclusão dos trabalhos.

Lehmann e Rodrigues Jr. (2001) estudaram os fatores que intermediam as interações entre orientadores e orientandos durante a dissertação de mestrado. Através de um estudo quantitativo, identificaram, na perspectiva do orientando, orientador e dos dois em conjunto, fatores que podem determinar o sucesso ou insucesso da conclusão de um projeto de dissertação da área de humanidades. Investigando os mestrandos que se titularam, os pesquisadores concluíram que, na medida em que o processo de orientação se sedimentava, características afetivas e de personalidade eram mais enfatizadas pelos sujeitos, principalmente pelos orientandos, passando a existir relações de parcerias entre orientadores e orientandos. As conclusões do estudo apontaram indícios de que um dos fatores de sucesso dos alunos no mestrado seria o bom relacionamento entre orientador e orientando.

Fernandes et al. (1993, p.103-113) estudaram os elementos inibidores e facilitadores do processo de elaboração da dissertação de mestrado na área de Administração. Os fatores inibidores revelados pela pesquisa foram a pouca experiência dos alunos na elaboração de textos acadêmicos volumosos; pouca clareza dos alunos sobre o tema que gostariam de pesquisar; dificuldades na escolha do tema da dissertação; uma acentuada tendência por parte dos professores orientadores de atribuir a responsabilidade pela elaboração da dissertação para o aluno; dificuldades do aluno em conseguir extrair conclusões e fazer a redação final do 
texto, refletindo a importância de uma maior preparação técnica dos alunos; a necessidade de se ampliar o contato com o orientador e com disciplinas de metodologia da pesquisa; falta de orientadores em número suficiente para atender a demanda dos alunos; e o pouco tempo destinado pelos professores à orientação dos alunos, aliado à pouca valorização institucional conferida à carga horária dedicada à orientação. Os elementos facilitadores relevantes evidenciaram a manutenção de contatos periódicos e freqüentes com o orientador como um dos aspectos mais importantes para o êxito no mestrado. Em patamar semelhante, situou-se a empatia mútua necessária entre orientador e orientando.

Segundo a investigação bibliográfica, Vasconcellos (1981) foi um dos pioneiros em pesquisas sobre o ambiente interno dos programas de pós-graduação na área de Administração. Apesar do seu artigo ter sido publicado no início da década de oitenta, os seus achados têm sido validados por várias pesquisas contemporâneas, efetuadas na década de noventa e no início dos anos 2000. Vasconcellos (1981) pesquisou o problema da produção de dissertações de mestrado, na área de Administração, destacando as barreiras apontadas por parte do orientando e do orientador no processo de construção dos trabalhos, chegando aos seguintes resultados: a falta de tempo dos professores para orientação, a pouca habilidade para orientar, orientadores em número insuficiente, falta de motivação para orientar os alunos, acúmulo de orientandos para alguns professores e necessidade de maior contato entre orientando e orientador. Tratando da questão da orientação, o referido autor relatou que:

É verdade que alguns orientadores têm tantos orientandos que não conseguem proporcionar um atendimento adequado. Outra barreira é a inexistência de professores capacitados a orientar certos temas de interesse dos alunos. As oportunidades de mercado de trabalho para a área de Administração e a política salarial da universidade fazem com que haja, relativamente, poucos docentes em tempo integral, reduzindo, portanto o tempo de orientação. (VASCONCELLOS, 1981, p.20) (grifo nosso)

Correa (1984, p.158-161) pesquisou os fatores relevantes na escolha de um tema de pesquisa, salientando que um dos momentos mais importantes na carreira de um aluno de pós- 
graduação ocorre quando ele escolhe o tema para sua pesquisa de mestrado ou doutorado. Observou que a escolha fora avalizada pela existência de uma pessoa habilitada para a orientação, ligada aos aspectos de importância e originalidade do tema e independência do orientando, enfatizando que “[...] é possível o pesquisador escolher um tema com ajuda do orientador e ele ser do seu inteiro agrado. Porém, se faz necessário que o pesquisador tenha vida própria, não ficando na dependência contínua do seu orientador.” Um dos resultados da sua pesquisa revelou que o orientando deveria ter autonomia para conduzir o processo de construção da dissertação de mestrado.

O estudo de Santos (1988, p.1009-1039) analisou o ambiente de produção de dissertações no curso de mestrado em Administração em uma universidade federal, chegando à conclusão que as condições de orientação dos alunos, por parte dos professores, foi um dos problemas mais representativos na construção dos trabalhos de dissertação. Os orientandos pesquisados relataram que existiam dificuldades ou barreiras na escolha do orientador, tais como falta de orientadores para o tema escolhido e a falta de disponibilidade de tempo do orientador. A pesquisadora identificou que tais problemas estavam relacionados à falta de experiência do corpo docente interno com a pesquisa e que vários professores exerciam a tarefa de orientação sem que, contudo, eles próprios tivessem executado ou terminado antes um projeto de pesquisa. O estudo apontou evidências de que a inexistência de um corpo docente qualificado, e com tempo disponível para a orientação dos alunos do programa, influiu de modo significativo para que os alunos não elaborassem as suas dissertações e não concluíssem o mestrado dentro dos cronogramas e padrões estipulados.

Confirmando as observações de Vasconcellos (1981), Correa (1984), Santos (1988), Fernandes et al (1993) e Freitas e Zawislak (2003), ao pesquisarem o desenvolvimento do 
mestrado em Administração de uma universidade federal, concluíram, por meio de entrevistas, que os alunos pesquisados evocaram, de modo não raro, uma falta de disponibilidade dos professores no acompanhamento dos orientandos, a falta de respeito dos mecanismos clássicos de relacionamento orientador-orientando como, por exemplo, o agendamento de encontros, que refletiram em problemas de prazos, qualidade e profundidade do trabalho final. Os autores também chamaram a atenção para os aspectos inerentes ao processo da orientação, indicados como de difícil controle institucional, subjetivos e impessoais. Sobre este tema, relataram:

[...] deveria se considerar os diferentes tipos e perfis (dos alunos, dos professores, dos métodos, dos temas e documentos) envolvidos no processo [...] a empatia e o respeito na relação orientadororientando, indo desde o mútuo interesse pelo tema até o tempo disponível para a orientação, passando pelo acesso do aluno ao professor, pelo pronto feed-back a trabalhos (de aula e de pesquisa), respeito da programação e dos prazos e a efetiva dedicação do orientando à pesquisa. (FREITAS; ZAWISLAK, 2003, p.8-9)

Godoy et al. (2000), em um estudo sobre as concepções e expectativas dos alunos sobre o programa de mestrado em Administração de uma universidade particular paulista, examinaram características e dificuldades que permeiam a qualificação destas pessoas em nível pós-graduado. Sobre a questão da orientação, 25\% dos entrevistados responderam que os alunos tiveram dificuldades de aceitação das condições de orientação, 55\% disseram que a falta de tempo dos orientadores e dedicação dos orientandos foram entraves para o sucesso das dissertações do programa. Sobre as condições ideais de orientação no mestrado, os sujeitos responderam que se deveria buscar uma orientação inicial e propuseram uma abertura e aproximação maior entre orientadores e orientandos.

Berndt (2003), ao pesquisar alunos desistentes do mestrado e doutorado em Administração da FGVSP e da FEA/USP, constatou que uma das razões mais significativas do abandono dos cursos pelos alunos, mesmo já com créditos concluídos, deveu-se a problemas relacionados à orientação. Segundo relatos dos alunos, tais fatores foram a falta de uma orientação mais 
efetiva da dissertação ou tese, com um peso de 14\%; a falta de tempo, de conhecimento, didática e dedicação dos professores ao programa de pós-graduação (12\%); e melhor organização dos horários de aulas e de encontros com os orientadores (23\%). Os resultados da pesquisa indicaram que um dos grandes problemas a ser enfrentado na área de Administração é a orientação de teses e dissertações.

Segundo o autor (2003, p.3-4), “[...] a real dificuldade, provavelmente, está no entendimento do orientando, da natureza específica de trabalhos da envergadura científica de uma tese ou dissertação”, tendo em vista que, geralmente, tal aspecto não é trabalhado de maneira satisfatória nos programas, por se tratar da introjeção de valores de pesquisa científica e fatores comportamentais relativos à prática de obtenção de novos conhecimentos. Aponta ainda as seguintes recomendações:

[...] planejamento do processo de orientação, visando a efetivação de contatos periódicos
freqüentes entre orientadores e orientandos. Práticas de reuniões entre alunos e professores visando
o acompanhamento de trabalhos, trocas de informações, de forma a aprimorar o relacionamento.
Conscientizar, tanto alunos como professores orientadores sobre a importância da empatia
entre orientador e orientando. Tal elemento é considerado prioritário na elaboração da
dissertação. (BERNDT, 2003, p.3-4) (grifo nosso) Estudos mais específicos sobre a relação orientador-orientando e concepções do papel do orientador foram descritos por Maher (1996), tendo o autor observado que as dificuldades que cercam a prestação de uma orientação adequada aos trabalhos não provêm apenas do fato de os professores dedicarem tempo insuficiente para realizar bem esta tarefa. Chamou a atenção para a existência de diferenças de opinião genuínas e arraigadas sobre qual deveria ser o relacionamento apropriado entre orientador e orientando. Segundo ele, estas diferenças se refletem em modelos de responsabilidade na relação orientador-orientando: um modelo encontrado comumente nas humanidades deve-se ao antigo padrão europeu de pós-graduação, no qual se supõe que o pós-graduando deva receber pouca ou nenhuma orientação, colocando o termo defesa de tese como sugestão da futura relação do pós-graduando com o corpo 
docente do departamento, sendo uma relação que antevê ataques, na qual comumente se encontram muitos orientadores no papel de atacantes. Neste ambiente, o estudante está na posição de quem deve implorar um título, como se fosse culpado até provar a sua inocência. Sobre a orientação, o autor relatou que:

\begin{abstract}
O fracasso do pós-graduando não é visto como um fracasso do sistema de orientação, mas como evidência da eficácia dos obstáculos que foram construídos para evitar que alguém que não merecesse o título ultrapassasse todas as etapas [...] No contexto deste modelo, o orientador pode ter muito pouco contato com o estudante e considerar a apresentação de avaliações críticas dos diferentes esboços de tese como um privilégio concedido ao estudante, e não uma responsabilidade profissional urgente. [...] os resultados inevitáveis desta abordagem são baixas taxas de doutoramento e o crescimento constante do número de anos para titulação. Mais difícil de demonstrar, embora real, é o sentimento de alienação e de solidão que invade os estudantes que tentam trabalhar nestes ambientes. (MAHER, 1996, p.14) (grifo nosso)
\end{abstract}

Confirmando os estudos de Maher, Velho (2003), ao observar a orientação nas ciências naturais e nas ciências humanas e sociais, descreve que, nas ciências sociais e nas humanidades, os estudantes de pós-graduação trabalham de forma muito independente, mesmo que eles estejam diretamente associados ao trabalho de pesquisa dos seus orientadores. A autora assevera que a razão por que os estudantes de doutorado nas ciências naturais recebem, em geral, mais orientação do que os das ciências sociais e humanidades deve-se ao fato de que os orientadores das ciências naturais recebem retornos positivos da orientação, refletidos num aumento significativo de produção científica, o que não ocorre nas ciências sociais e humanidades. A autora ressaltou que uma maior colaboração entre orientadores e orientandos nas ciências humanas e sociais poderia aumentar o interesse dos professores em usar mais tempo na orientação, diminuir o tempo de titulação e o índice de abandono nos programas, pois:

[...] Sabe-se que na prática a orientação é freqüentemente inadequada em intensidade e qualidade. Existem limites para o número de estudantes de mestrado e doutorado que qualquer indivíduo possa orientar: um aspecto que é muitas vezes esquecido ou ignorado. Além disso, é necessário reconhecer que muitos pesquisadores universitários consideram a orientação uma tarefa bastante difícil: ela requer uma combinação sutil de habilidades. Experiências relatadas na literatura dão conta de que discussões estruturadas em grupo sobre problemas e práticas na orientação têm sido particularmente eficientes em melhorar a prática sobre a orientação. (VELHO, 2003, p.10) (grifo nosso) 
O estudo de Loui (2003), intitulado “Como Escolher um Orientador de Teses”, apresentou a importância dos encontros freqüentes e programados dos orientandos com os seus orientadores, mencionando, assim como Velho (2003), que um dos problemas mais comuns nas ciências humanas e sociais são os encontros insuficientes e ineficazes entre os orientandos e os orientadores, culminando, muitas vezes, no abandono do programa de pós-graduação pelo orientando. Sobre a escolha do orientador de trabalhos acadêmicos relatou que:

Realmente, a escolha do orientador é semelhante a um casamento: está fazendo um compromisso a
longo prazo. Porém, é distinto do matrimônio, é uma relação de assessoramento que deveria
terminar prosperamente dentro de alguns anos. Também, a relação orientador-orientando não
começa como termina. No princípio, a relação é essencialmente um aprendizado. Mas embora
você comece como um aprendiz, você termina como um colega. (LOUI, 2003) ${ }^{1}$ (Tradução Livre).

Segundo Brown e Adkins (1998), a orientação de alunos da pós-graduação é provavelmente um dos mais complexos e delicados problemas para a dedicação e reflexão dos professores. Para uma orientação efetiva, o professor deveria ser um pesquisador competente e com conhecimentos, habilidades e práticas de pesquisa, técnicas e métodos que a tornem efetiva. O orientador deveria ajudar os alunos orientandos a adquirir conhecimentos de pesquisa sem prejudicar o seu desenvolvimento pessoal e intelectual.

Mesmo diante das observações de Loui (2003) e Brown e Adkins (1998), estudos têm demonstrado que os alunos não têm terminado os seus trabalhos de pós-graduação em função de problemas relacionados com a orientação. Madsen (1992), ao estudar os motivos por que os estudantes não completam as suas dissertações e teses na Grã-Bretanha, concluiu que:

[...] os fatores incluem o abandono prematuro das atividades na universidade, muito entusiasmo para a pesquisa, porém sem foco, abordagem muito casual, problemas emocionais (compulsivo, também isolamento e sentimentos de solidão) e tendo pouca avaliação da tradição escolar [...] os estudantes não completam a dissertação por várias razões: dinheiro curto, discórdias matrimoniais e outros problemas pessoais que tornam a concentração difícil, dificuldades na

\footnotetext{
1 "Indeed, choosing an advisor is similar to getting married: it is making a long-term commitment. Unlike marriage, however, a good advising relationship should end successfully within a few years. Also, unlike husband and wife, the advisor and student do not start as equals. At first, the relationship is essentially an apprenticeship. But although you start as an apprentice, you should end a colleague."
} 
escolha do tópico de dissertação que provoca uma falta de entusiasmo no próprio ambiente acadêmico [...] Estes estudantes não terminam, precisamente porque o processo exige um grau alto de independência e auto-motivação. (MADSEN, 1992, p.6) ${ }^{2}$ (grifo nosso) (Tradução Livre)

Abordando a natureza e o processo da orientação, Piccinin (2003) observou que a orientação a alunos de pós-graduação envolve um longo relacionamento pessoal e profissional entre o estudante orientando e o professor orientador que inclui a seleção do tópico da pesquisa, planejamento da pesquisa, identificação e levantamento da necessidade de recursos, gerenciamento do projeto, condução ativa da pesquisa, levantamento e revisão da literatura, análise e interpretação dos dados, escrita da tese ou da dissertação, defesa, publicação do trabalho e descoberta de uma posição. O autor ressalvou que este processo, geralmente, estende-se por muitos anos e torna-se mais complexo devido ao aumento do número e da diversidade dos estudantes de pós-graduação. Como conseqüência destes fatores, o processo requer constantes ajustes, grande sensibilidade e habilidades de relacionamento interpessoal entre orientadores e orientandos. Concluiu que a evasão dos cursos de pós-graduação tem ocorrido em função da não observância dos aspectos anteriormente citados.

Tunes (1981), em pesquisa de doutorado em Psicologia, interessou-se em conhecer e pesquisar o porquê das dificuldades dos alunos em um programa de pós-graduação em nível de mestrado, uma vez que estes, em seus relatos, apontavam com freqüência as razões pelas quais justificavam não estar conseguindo realizar, de maneira satisfatória, suas atividades de pesquisa. Um exame dos depoimentos permitiu-lhe apontar evidências de três agrupamentos das razões indicadas pelos alunos, dentre eles a questão da orientação, a saber:

\footnotetext{
2 “[...]factors include leaving the university early, too much enthusiasm but too little focus, being too hard to please, too casual in your approach, too compulsive, too isolation and having little appreciation of the scholarly tradition [...] students fail to complete the dissertation for a number of reasons: money runs short, ennui sets in, marital discords, and other personal problems make concentration difficult, the dissertation topic proves elusive or unmanageable and enthusiasm wanes [...] one reason some students never finish the dissertation stems from the structured nature of the academic environment itself. These students do not finish precisely because the process demands a high degree of independence and self-motivation."
} 
[...] as condições institucionais, a estrutura dos programas e as condições da biblioteca; características do próprio repertório do aluno, como, por exemplo, não saber desenvolver atividades de pesquisa; as condições de ensino e aprendizagem, a orientação recebida, a relação professor-aluno, inadequação das atividades desenvolvidas nas disciplinas durante o mestrado; a influência do relacionamento orientador-orientando nas atividades de pesquisa dos alunos. (TUNES, 1981, p. 6) (grifo nosso)

O trabalho de doutoramento em Psicologia de Luna (1983) discutiu e analisou as dificuldades de elaboração de teses e dissertações de um programa de pós-graduação em Psicologia em uma universidade pública, a partir de prováveis contingências que controlam essa atividade, destacando, dentre as limitações, o relacionamento orientador-orientando. A pesquisa do autor revelou os seguintes resultados:

- Fontes de problemas para a dissertação ou tese: dificuldades surgidas durante o curso das disciplinas, problemas teóricos, modismos, compromissos com outras atividades pessoais, orientadores como fontes de problemas de relacionamento.

- Dificuldades por parte dos alunos: dificuldades de comunicação e expressão, a falta de tempo, recursos materiais e econômicos, dificuldades associadas ao projeto de pesquisa, desconhecimento das regras da instituição, problemas no relacionamento com os professores.

- Dificuldades por parte dos professores orientadores: condições de trabalho, principalmente a falta de tempo para as orientações, número excessivo de alunos orientandos, mistura de problemas pessoais no processo de orientação.

Apesar de ter sido escrita ainda no início da década de 80, o trabalho de Luna (1983) merece atenção especial, pois, se comparado a textos mais recentes, nota-se que pouca coisa mudou de lá para cá. O referido autor pesquisou também como era delineada a relação orientadororientando, chegando aos seguintes resultados de entrevistas com alunos e professores: 
[...] não tenho procedimentos definidos, fico mais na dependência do aluno [...] sou pouco diretivo, minha interferência ocorre em termos de indicar possibilidades para encaminhar o projeto ou considerar que o rumo tomado poderá torná-lo inviável, complicado ou menos relevante [...] sou apenas um interlocutor do projeto, nunca digo o que deve ser feito nem como deve ser feito, digo apenas o que não deve ser feito em função do repertório do aluno, das condições existentes ou da viabilidade do projeto [...] a função do orientador não é fazer a cabeça do aluno, mas sim ensiná-lo a fazer a própria cabeça [...] estabeleço com o aluno as regras do jogo, sendo diretivo: está certo, está errado, faça, não faça, etc. [...] vou trabalhando junto, mas se o aluno começa a se perder, começa a enrolar, aí eu viro diretivo e começo a dar as instruções [...] o professor participa excessivamente dos meus projetos [...] o professor avalia a qualidade/adequação do pesquisador, adequação do problema, objetivos e métodos [...] Eu entro em conflito entre recusar as coisas que eu não aceito e o medo de estar me impondo indevidamente ao aluno. (LUNA,1983, p.99)

Luna (1983), em uma análise mais detalhada das respostas, encontrou indícios de que os professores orientadores desempenharam um papel bem mais diretivo do que sugeriram em suas entrevistas. Observou que um dos principais critérios para aceitação dos alunos pelos professores foi o interesse na área do projeto do aluno, o que tornou inevitável algum tipo de envolvimento do professor além do desenvolvimento da pesquisa, pois “[...] o importante é analisar que a atividade de orientação vai além de ser um mero supervisor [...] a relação orientador-orientando para o professor, ultrapassa os limites de um supervisor de projetos” (LUNA, 1983, p. 193).

Por outro lado, o autor observou que existiam desequilíbrios no relacionamento orientadororientando, pois, segundo os dados empíricos, a maioria dos professores indicou ter rompido a relação, encaminhando o aluno para outro orientador. As razões alegadas, em geral, situaramse na incompatibilidade pessoal ou na forma de trabalho. Todavia, o autor não encontrou referências de rompimento por parte dos alunos, observando o poder exercido pelos orientadores sobre os orientandos.

Martins (1997, p.58), em sua pesquisa sobre o relacionamento orientador-orientando nos programas de pós-graduação em Administração, relatou que “[...] a autocracia que domina as relações dentro dos programas de pós-graduação dificulta o relacionamento eficaz entre 
orientador e orientando.” O autor notou que “[...] o processo de construção de relações democráticas ainda sofre os efeitos de atitudes e comportamentos diametralmente opostos, tanto do orientador quanto do orientando.” Tais afirmações vão ao encontro de uma das conclusões da dissertação de mestrado de Sanches (1992), na qual o autor evidenciou a falta de consenso entre professores dos programas de pós-graduação em relação ao que se espera dos orientandos.

Sanches (1992) verificou que a falta de expectativa com relação à orientação implicara em problemas e dificuldades de toda ordem, evidenciadas no seguinte relato:

[...] aluno escolhendo a esmo seu orientador, guiando-se por comentários geralmente carregados
de juízos de valores ou, como é comum, por ter freqüentado o curso com o professor, a partir do
qual identificou ou idealizou proximidades em termos de área de interesse de estudos, simpatia
pessoal, empatia [...] A inexistência de parâmetros claros sobre as características que deve ter o
trabalho a ser executado pelos mestrandos inviabiliza conclusões sobre a adequação, ou não, de
prazos, conteúdos e exigências. (SANCHES, 1992, p.91) Ratificando Sanches, Warde (1997, p.165) observou que os problemas das fronteiras que delimitam e definem as relações orientador-orientando não são de mão única, ou seja, do orientando para o orientador. Os problemas que vão do orientador para o orientando, em regra, são mais graves, embora mais sutis. Para a autora, “[...] aí está em jogo o exercício do poder. É sempre mais fácil imputar ao aluno as culpas dos maus ou precários resultados obtidos ou do insucesso do processo de orientação.”

A ausência de uma responsabilização do orientador no processo de orientação poderia acarretar também uma supervalorização do trabalho monográfico para o aluno, como relata Martins (1997, p.58):

Há uma mistificação que a dissertação ou tese acaba tomando uma dimensão irreal e distorcida, provocando maior angústia, sobretudo na capacidade pessoal do aluno em desenvolver seu próprio trabalho [...] cria-se a expectativa de realização de um trabalho sem erros e socialmente relevante. Em decorrência das limitações, deformações e das expectativas, emergem fortes sentimentos de angústia que afetam todo o processo. 
Corroborando esta afirmação, a pesquisa de dissertação de Carvalho (1994, p. 73) apresentou algumas conclusões que poderiam explicar tal situação. Segundo a pesquisadora, alguns pósgraduandos “[...] apresentam paralisação e lentidão na elaboração dos seus trabalhos porque carregam em seu interior elevadas ambições relativas aos mesmos [...] o atraso na finalização da obra pode ser uma forma, indireta, de evitar o produto final.” Os resultados principais da sua pesquisa sobre esta problemática indicaram que o mestrando tem inúmeros anseios profundos, presença de elevadas expectativas que o levam a se deparar com a vivência de angústias e, ainda, a figura do orientador fica permeada de alto grau de ambivalência, o que contribui para dificultar, em certas fases, um diálogo real com o mestrando. A autora também concluiu que, além da falta de incentivos e de recursos financeiros, aspectos subjetivos também influenciaram na ocorrência de dificuldades na elaboração da dissertação, e que algumas situações institucionais, tais como dificuldades no relacionamento orientadororientando, favoreceram a proliferação de entraves no trabalho.

Na mesma linha de Carvalho e Sanches, Frame e Allen (2002) estudaram os fatores que afetam o sucesso dos alunos de um curso de doutorado em uma universidade inglesa. Através do relato e da opinião dos próprios alunos, foram apontadas evidências de diferenças de opiniões entre professores orientadores e alunos orientandos, validando os achados de Maher (1996). Os autores sugeriram no estudo que, para auxiliar os alunos frente às suas diferentes necessidades, os orientadores poderiam ter uma maior aproximação e abertura com os orientandos, pois:

A acessibilidade de um orientador, sem sobras de dúvidas, é um fator crucial de sucesso na relação
orientador-orientando. [...] De forma interessante, nossa pesquisa apontou um descompasso entre
percepções do estudante e percepções do seu orientador: enquanto, virtualmente, todos
supervisores informaram que eles freqüentemente encontravam com os seus estudantes
(orientandos), os estudantes descreveram problemas de acesso com os seus orientadores. Este
descompasso pode refletir uma diferença verdadeira de percepções da "acessibilidade": quando
exigido, um orientador teria realmente tempo suficiente para discutir a orientação detalhada do
projeto de pesquisa do doutorado? Além disso, na pesquisa com estudantes egressos, por volta de 
25 por cento alegaram grande "descontentamento" com a questão da acessibilidade do orientador. (FRAME; ALLEN, 2002, p.98) ${ }^{3}$ (Tradução Livre)

Complementando Frame e Allen, Warde (1997, p.164), falando da sua experiência como orientadora, observou que “[...] não se improvisa um professor de pós-graduação; mais do que isso, não se cria da noite para o dia um orientador. Se um erro na sala de aula é grave, qualquer erro no processo de orientação é fatal.” A autora notou ainda que cada orientando e cada relação de orientação são únicos e exclusivos e cada nova orientação instaura regras novas de relacionamento acadêmico e pessoal, sendo que a relação orientador-orientando transcende os aspectos burocráticos e formais, conforme o exposto abaixo:

[...] não tenho dúvida sobre o fato de que a relação orientador-orientando é seguramente das mais
personalizadas dentre as que podemos manter no universo acadêmico; como tal é sempre
arriscadamente intimista; por isso, nos tenciona sempre em dupla direção: de um lado da generosa
compreensão dos problemas de diversa natureza que envolve os orientandos; de outro, da dura
obrigação de fazê-los cumprir seus prazos, de exigir o retorno dos investimentos públicos neles
aplicados mediante bolsas de estudo sob a forma de uma mais alta qualificação e a produção de
uma tese ou dissertação que respeite, pelo menos, o critério de relevância. (WARDE, 1997, p. 164-
165) No entendimento de Severino (2002, p.154), a orientação deveria ser um processo que efetivasse uma relação essencialmente educativa, na qual o orientador desempenhasse o papel de um educador “[...] cuja experiência, mais amadurecida, interage com a experiência em construção do orientando [...] um diálogo em que duas partes interagem, respeitando a autonomia e a personalidade de cada uma.” Na visão do autor seria fundamental entender-se devidamente este convívio como uma relação educativa que pressupõe necessariamente um trabalho conjunto em que ambas as partes possam ter enriquecimento recíproco numa interação dialética, onde esteja ausente qualquer forma de opressão ou submissão.

\footnotetext{
3 "The accessibility of a supervisor is of course a crucial factor in fostering the student-supervisor relationship. [...] Interestingly, our research found a mismatch between student and supervisor perceptions; while virtually all supervisors reported that they met frequently with their students, around a quarter of students described problems in accessing their supervisor. This mismatch may reflect a difference in perceptions of what 'accessibility' truly means; when required, does a supervisor have sufficient time to discuss a PhD research project in-depth? Furthermore, in the Trust's annual 'exit' survey of final year students, around 25 per cent express 'dissatisfaction' ; accessibility of the supervisor is consistently mentioned as part of this."
} 
A seguir, apresenta-se argumentação teórica sobre as funções e papéis de orientadores e orientandos no contexto da pós-graduação.

\subsection{Concepções, problemas e funções do orientador e orientando}

Verificou-se que nem sempre há entendimento sobre as funções, deveres e obrigações dos orientadores e dos orientados no ambiente da pós-graduação, dando idéia de ser uma atividade auto-explicativa, dispensando maiores esclarecimentos e informações. Existem várias posições assumidas perante este relacionamento: alguns entendem que o orientando deve pesquisar assuntos de interesse do orientador e trabalhar sob um rígido esquema por ele determinado; outros já deixam o orientando totalmente solto, numa situação de total independência, até mesmo perdido. Nesse aspecto, observou-se também que os regulamentos dos programas de pós-graduação trazem vagas descrições (quando trazem) sobre aspectos da atividade de orientação.

Programas de pós-graduação das áreas das ciências duras (Biologia, Física, Química e Matemática) têm a tradição de divulgar as vagas dos seus cursos em função da disponibilidade de orientadores. Entretanto, na área de humanidades e ciências sociais, não se tem levado a termo esta disponibilidade de orientadores, pois os alunos, em função dos seus interesses de pesquisas, são os que escolhem os professores orientadores, muitas vezes culminando na saturação do número de alunos orientandos para alguns orientadores mais solicitados, ou a indicação de professores para orientação pelos coordenadores do programa, sem análise da compatibilidade de projetos, idéias e ideologias. 
Nesse sentido, Eco (1998, p.34) ressaltou que o aluno de um programa de pós-graduação, para escolher um orientador, deveria fazer uma pesquisa acerca das características técnicas e pessoais deste professor, pela leitura das obras de sua autoria ou pela coleta de informações com diplomados e orientandos anteriores, entrando nesta investigação fatores de estima e confiança, pois, segundo o autor, “[...] ao aceitar o desafio de escrever uma tese, o estudante deve verificar se está inserido ou não num trabalho coletivo, e pensar se vale a pena fazê-lo.” Com isso, o autor demonstra a necessidade do conhecimento acerca das funções técnicas e das características pessoais dos indivíduos participantes do processo de pós-graduação.

Para Haguette (1994, p.162), a função do orientador não tem recebido e merecido muita atenção dentro das discussões acadêmicas, visto que a precariedade do processo educativo das universidades tem forçado o orientador a assumir funções complementares que não lhe diriam respeito. Mediante as ressalvas citadas, a autora propôs tópicos denominados de “mandamentos do orientador” destacando-se:

\footnotetext{
Não discutir o problema de pesquisa com o aluno, exigir que ele se expresse por escrito [...] não fazer imposição de problemática ao aluno, ele goza de autonomia para escolher o fenômeno que lhe aprouver analisar [...] respeitar a lógica do aluno: não impor a nossa. [...] o nível de exigência deve estar em consonância com as potencialidades do aluno [...] exigir metodologia rigorosa, caso o orientador não tenha competência nesta área, incluir um bom pesquisador na banca para garantir o êxito da pesquisa. [...] transmitir otimismo e confiança ao orientando [...] manter relacionamento profissional, porém amigável e regular com o orientando, estabelecendo um cronograma de atividades. [...] ao fazer críticas e reparos, explicar as razões e indicar os caminhos possíveis. (HAGUETTE, 1994, p.162).
}

Haguette salientou que, aos aspectos citados sobre orientadores, poder-se-iam acrescentar direitos específicos do orientando, como ser atendido periodicamente pelo orientador e ter seus textos lidos, anotados e devolvidos para posterior discussão. As idéias subjacentes às colocações da autora demonstram que os sujeitos - orientadores e orientandos - necessitam estar em sintonia e conhecer as suas prerrogativas para que o processo de orientação se realize de maneira satisfatória. 
No entendimento dos direitos e deveres dos orientadores, Castro (2002, p.134) salientou que estes deveriam permitir e estimular divergências de opiniões entre orientandos e eles próprios, “[...] levando a sua crítica ao extremo daquilo que pode ser demonstrado factualmente ou teoricamente”, contribuindo para o crescimento intelectual dos orientandos, pois:

[...] orientadores variam em seus estilos de trabalho [...] alguns vetam sucessivamente até que os
alunos consigam chegar finalmente por conta própria à solução correta, outros quase chegam a
fazer o trabalho para o aluno. Naturalmente, alguns têm mais tempo ou maior disposição para
gastá-lo com seus alunos. É importante que o aluno conheça antecipadamente as regras do jogo e
as idiossincrasias do orientador. Para Ferreira Sobrinho (2004), o processo de orientação consiste em uma leitura e discussão conjuntas, num embate de idéias, de apresentação de sugestões e críticas, de respostas e argumentações. Ressalta que, além dos aspectos afetivos, o orientador poderia nortear a sua relação com o orientando com base em três dimensões: o conteúdo, para indicar as fontes de material bibliográfico para a pesquisa; o método, para demonstrar os caminhos metodológicos; e a forma, para a apresentação e normatização do trabalho científico.

Para Lehman (1988), o orientador poderia ajudar o orientando a elaborar um projeto para a sua vida científica, através das identificações conscientes e inconscientes subjacentes à escolha do indivíduo. A autora assevera que essa nova forma de contextualizar a orientação poderia também envolver o próprio orientador, que teria de contribuir para que o orientando, ao assentar sua identidade profissional, considerasse o contexto educacional e histórico-social. Observa ainda que, tanto na visão do professor quanto na do aluno, faz-se necessária esta reflexão para evitar que o aluno sinta a necessidade de adaptação a uma nova realidade, na estrutura social e educativa, por causa de problemas pessoais.

Henriques e Medeiros (1999) relataram que a função principal do orientador é puxar os fios para que o orientando possa iniciar o trabalho de tecer sua dissertação ou tese, abrindo os 
caminhos, apontando os roteiros e colocando o aluno na via certa. Os autores apontaram três características importantes do orientador:

a) A competência, pois o orientador deveria ter conhecimento amplo e profundo da matéria em pauta.

b) A responsabilidade, pois a aceitação da tarefa de orientar um candidato implica honestidade e dedicação. O trabalho de orientação deveria ser levado a sério, sendo que, na agenda do orientador, deveria haver sempre um espaço aberto para a análise crítica da dissertação ou tese e para o atendimento do orientando, no entendimento que a figura do orientador não é decorativa ou simples formalidade de um curso de pósgraduação.

c) A afabilidade, pois é de suma importância um clima amigável que leva o orientando a sentir-se bem ao lado do orientador e a predispor-se a aceitar as propostas. A ação do orientador deveria ser um pólo de atração, não de repulsa. Cabe ao orientador, como verdadeiro educador, manter as portas abertas para o diálogo, de aproximação, que desperte iniciativas.

Além disso, Henriques e Medeiros (1999) observaram que o orientando deveria conscientizarse da necessidade de confiar no orientador, acolhendo as sugestões e as correções de rumo na elaboração da dissertação ou tese. O orientando, contudo, não deveria se colocar num estado de passividade, pois, sendo a monografia de sua lavra, deveria espelhar seus pontos de vista, bem como a peculiaridade do seu estilo, embora muitas vezes este fato não tenha acontecido em decorrência de distorções no processo de orientação.

Maroni Neto (2003, p.101-102), no entendimento da orientação como etapa do processo de 
ensino-aprendizagem, propôs os seguintes passos que deveriam ser seguidos pelos orientadores:

a) ler sempre todo o material apresentado, afinal, por pior que o texto esteja, é o resultado do esforço de alguém que quer a opinião do orientador; b) criticar o trabalho apontando as suas deficiências, porém faz-se importante explicar os porquês, o que falta e como melhorar, indicando, desta forma, soluções para o orientando; c) demonstrar que o orientando não está só, pois, por mais que a família o apóie, o aluno sempre precisa de alguém para discutir, motivar e cobrar, neste vácuo o orientador é fundamental; d) chamar, quando necessário, a atenção do aluno à responsabilidade, uma vez que a monografia é um desafio e, muitas vezes, por inexperiência, escapa ao aluno o senso de dever; e) as atividades de orientação requerem que o professor orientador seja um pesquisador e, por conseguinte, domine o processo de pesquisa, se possível tenha lecionado alguma disciplina para os alunos que irá orientar, atue como líder e gerencie as pessoas para obter resultados, anteveja as dificuldades sistêmicas dos alunos. (MARONI NETO, 2003, p.101-102)

Machado (2002, p.45-57), pesquisando e trabalhando os obstáculos entre o sujeito e sua escrita, notou que, nos cursos de pós-graduação, a atividade do orientador de teses e dissertações desempenha papel fundamental no processo subjetivo de tornar o aluno orientando um autor. Ressaltou que, na fase de escrita do trabalho, é também ainda muito alto o índice de pós-graduandos que obtêm os créditos, mas não conseguem escrever seus trabalhos, gerando frustração e ônus para os programas, para si próprios e para os orientadores. Para a autora, “[...] o trabalho de orientação é um espaço nunca antes concedido ao aluno, um espaço no qual ele pode desenvolver as capacidades adquiridas, mas, raramente, praticadas antes e, por essa razão tão simples, fadadas ao desperdício.”

Confirmando as posições de Machado, Marques (2002, p.227-231) tem notado em suas pesquisas que uma das principais dificuldades dos orientandos é a redação dos trabalhos, asseverando que cabe ao orientador ler com atenção o que o orientando escreve, auxiliando-o com sugestões que o levem a produzir seus próprios saberes com autonomia e competência. O autor relata que o orientador é um educador que busca inserir o orientando no “[...] fazer-se homem, entre homens, pesquisador entre pesquisadores, ao mesmo passo que um sujeito singularizado de seus próprios saberes, com autonomia e competência.” 
Ferreira Sobrinho (2004, p.6-10) apresentou, como resultado de estudo de entrevistas informais com orientandos, três tipificações características de orientadores relatadas e indicadas por estes sujeitos. O primeiro tipo referiu-se ao orientador formal ou nominal, aquele que só entra com o nome no trabalho, pois, por ser um profissional famoso e reconhecido, não tem tempo para dedicar-se à leitura do material produzido pelo orientando ou auxiliá-lo nas suas ações de pesquisa. Relatou que “[...] esta personificação de orientador deveria ser abolida da universidade, por causar um mal indescritível ao orientando, um charlatão educacional que não entende a vivência do vocábulo educador.” O segundo tipo referiu-se ao orientador tirano que, ao contrário do primeiro tipo, disponibiliza tempo para atendimento aos orientandos, mas não permite que estes tenham idéias diferentes daquelas que ele apresenta. O autor observou que “esses verdadeiros coronéis de cátedra” não mantêm diálogos com os orientandos, sufocando-os intelectualmente, ficando estes indivíduos impossibilitados de qualquer iniciativa. "Nessas relações unilaterais, o orientando tem a sensação que está fazendo a pesquisa do orientador, e não a sua.” O terceiro tipo categorizou como orientador desejável que, conforme o autor, além de ter tempo para os encontros, discute com o orientando todos os caminhos da pesquisa, numa relação em que prevalece o diálogo. O autor ressaltou ainda que, para se ter sucesso nos encontros de orientação, a relação orientador-orientado necessitaria ser dialógica, sem que o orientador exercesse o papel de opressor e o orientando de oprimido, corroborando com as observações de Severino (2002), Maroni Neto (2003) e Henriques e Medeiros (1999).

Costa (2004), falando das considerações sobre a orientação, advoga que a fase da elaboração da dissertação é um período de grande angústia para os orientandos. Pela sua experiência como revisora de textos, pôde perceber problemas mais sérios que a ortografia, gramática e 
organização textual das dissertações que chegaram às suas mãos, que a levaram a refletir sobre a orientação (e em alguns casos desorientação) nos programas de pós-graduação. Nesse contexto, a autora classificou três tipos de problemas que chamaram sua atenção, relativos às atividades de orientação: o primeiro referiu-se à falta de planejamento e acompanhamento das atividades, por parte do orientador, que muitas vezes realizava cortes no texto do orientando, sendo que, no encontro seguinte, solicitava ao aluno que desenvolvesse o tema que fora cortado anteriormente, num comportamento totalmente errático decorrente da falta de planejamento de orientação e sintonia com o trabalho. Para a autora, o segundo problema, bastante usual e facilmente solucionável, estava relacionado às dificuldades de se encontrar o orientador, seja porque ele faltava aos encontros marcados, ou porque tinha tantas outras atividades que não restava tempo para os orientandos, deixando estes alunos totalmente soltos e sem direção. O terceiro problema, segundo a autora o mais significativo, referiu-se à qualidade da orientação recebida, traduzindo-se na dificuldade do orientando em delimitar o objeto da pesquisa, não ficando clara qual seria a questão do trabalho, além da não observância das normas e dos padrões seguidos pela universidade.

As tipificações de orientadores apresentadas por Ferreira Sobrinho (2004) e as considerações e problemas relatados por Costa (2004), Maroni Neto (2003), Machado (2002) e Marques (2002) despertam a atenção para questionamentos sobre o tipo de orientação que vem sendo prestada na pós-graduação e sobre o papel, deveres, obrigações e regras de condutas de orientadores e orientandos. A universidade deveria preocupar-se com a preparação do professor orientador, municiando-o de instrumentos e de incentivos que permitissem a ele desempenhar bem as suas atividades, e ainda oferecer aos orientandos e orientadores um conteúdo mínimo que os habilitasse para a missão a que se propõe. Deve-se atentar também para a necessidade de maiores esclarecimentos sobre o papel dos sujeitos no processo de 
orientação, com vistas a minimizar conflitos, uma vez que os orientandos têm o direito de saber o que lhe será exigido, assim como o direito de serem assistidos pelos orientadores.

Neste sentido, para a superação dos problemas na orientação e no relacionamento orientadororientando, Martins (1997, p.59) aconselhou que a utilização de referencial teórico acerca de noções de aconselhamento e orientação educacional poderia ser parte integrante e imprescindível da orientação de trabalhos de pós-graduação, constituindo-se num interessante referencial empírico-teórico para análises e estudos sobre o relacionamento orientadororientando no processo de elaboração de um trabalho científico. Segundo o autor, “[...] a orientação educacional e o aconselhamento teriam por finalidade promover um melhor ajustamento do estudante a fim de que este pudesse desenvolver as suas potencialidades.” Afirmou ainda que os orientadores poderiam apropriar-se de conceitos e práticas do aconselhamento psicológico visando a construção de um método que possibilitaria alcançar um grau de formalização e sistematização que alavancasse o processo de elaboração de dissertações e teses nos programas de pós-graduação.

Outra consideração seria o modelo de orientação coletiva. Santos Filho e Carvalho (1991), relatando a experiência bem sucedida deste modelo em uma universidade estadual brasileira, ressaltaram sua potencialidade para superar uma série de problemas relacionados à orientação de pesquisas. Esta experiência revelou os seguintes aspectos positivos:

a) Pluralidade de perspectivas teóricas e metodológicas no tratamento do tema da pesquisa;

b) Melhor assistência aos orientandos, que se beneficiaram com as diferentes competências dos orientadores, tanto na dimensão teórica como metodológica; 
c) Racionalização do trabalho de orientação com maior efetividade dos mestrandos no trabalho de levantamento bibliográfico e revisão de literatura;

d) Alto índice de produtividade dos mestrandos, além do padrão de qualidade do produto das pesquisas apresentarem patamar superior à média, segundo avaliação dos orientadores.

Garcia e Alves (2002, p.282-292), ao relatarem as experiências de orientação coletiva na área de Educação, observaram que “[...] o olhar do outro garante que cada um enxergue seus pontos cegos [...] precisamos do olhar do outro, o que cria um movimento de solidariedade epistemológica.” Para as autoras, a discussão coletiva no processo de orientação de trabalhos de pós-graduação fez surgir diferenças notáveis e salutares entre os participantes dos grupos de pesquisa, revelando qualidades importantes dos orientadores e orientandos, como a apresentação de críticas sem omissão de relatar tudo o que era necessário; desenvolvimento de atenta leitura do texto dos outros procurando contribuir com o que antes fora discutido e lido; organização das idéias lidas nos textos do outro, destacando formas de escrita ou conteúdos originais.

As considerações de Santos Filho e Carvalho (1991) e Garcia e Alves (2002) dão evidências de que o modelo coletivo de orientação poderia ser uma opção para resolução de problemas de natureza institucional e individual, identificados pela literatura especializada como condicionantes ao fracasso, longa permanência da maioria dos pós-graduandos nos cursos, ou mesmo da sua formação deficiente. Segundo Santos Filho e Carvalho (1991, p.79), após a implantação do modelo, “[...] o apoio do grupo elevou a moral e auto-confiança dos pósgraduandos, conseguindo reduzir os índices de evasão.” 
Por meio da discussão do referencial teórico apresentado, percebeu-se que o sistema nacional de pós-graduação experimentou um excelente crescimento em termos quantitativos nas décadas de 1990 e 2000. A área de Contabilidade, apesar de ter acompanhado este crescimento, apresentou-se carente quanto ao número de programas de mestrado e doutorado e quanto à sua distribuição em termos regionais.

Sobre aspectos internos dos programas de pós-graduação, diversos especialistas, autores e pesquisadores trouxeram à tona a discussão de um aspecto que demanda atenção: a orientação e a relação orientador-orientando. A contribuição dos diversos trabalhos que versaram sobre esta temática dão idéia da complexidade e da necessidade de investigações mais apuradas sobre esta temática. Vários estudos apontaram que a orientação e a relação construtiva entre orientadores e orientandos têm qualificado os pós-graduandos para a autoria, tendo este aspecto associação com a qualidade da sua produção textual.

Verificou-se também que a prática da atividade de orientação destituída de preparo e treinamento, aliada à falta de contato entre orientadores e orientandos, poderia acarretar problemas de diversas ordens, culminando na não conclusão dos projetos pelos pósgraduandos, além de engendrar sentimentos negativos nestes sujeitos. Autores também relataram que a função do orientador não tem recebido atenção nas discussões acadêmicas, culminando assim em variadas atitudes e posicionamentos assumidos a este respeito. O capítulo também apresentou sugestões para minimizar problemas na orientação, dentre os quais o uso de noções de relacionamento interpessoal, orientação educacional e modelos de orientação coletiva, já utilizados com sucesso em outras universidades brasileiras. 
Com o intuito de investigar aspectos da relação orientador-orientando nos programas de pósgraduação em Contabilidade, o próximo capítulo enuncia os caminhos metodológicos que foram utilizados para se proceder à elaboração desta pesquisa. 


\section{ABORDAGEM METODOLÓGICA}

O objetivo deste capítulo é discorrer sobre os caminhos metodológicos utilizados para a construção deste trabalho, descrevendo-se os passos da investigação, a opção de escolha pela pesquisa qualitativa, as técnicas e procedimentos utilizados, os sujeitos participantes da investigação empírica, os critérios de validação do roteiro de entrevistas e as limitações apresentadas no estudo.

\subsection{O tipo de pesquisa}

O curso de graduação e os programas de pós-graduação em Contabilidade são classificados pela CAPES e MEC dentro da área de Ciências Sociais Aplicadas. Conforme Goode e Hatt (1960, p.5), a possibilidade de realizar pesquisas em ciências sociais reside no fato de que os acontecimentos humanos e sociais não se dão por acaso, ao contrário, estão sempre interligados por relações que, mesmo não estando explícitas, evidentes ou conscientes, incitam a função da Ciência Social, que é a procura e a descoberta destas relações, objetivando explicar os fatos.

O presente estudo pesquisou aspectos da relação orientador-orientando que teriam ligação com a construção das dissertações e teses elaboradas nos programas de pós-graduação em Contabilidade na cidade de São Paulo. Nesta investigação, buscou-se verificar a perspectiva dos participantes no processo de orientação, através da descrição dos seus comportamentos e experiências. Esta tentativa de compreensão dos significados e das características situacionais da relação entre orientadores e orientandos, apresentadas pelos sujeitos pesquisados, indicaram a opção por uma pesquisa de caráter qualitativo. 
A pesquisa qualitativa tem como principal foco a compreensão de aspectos do comportamento humano, preocupando-se em explicar seus significados. O pesquisador é o principal instrumento de investigação, importando-se com a verificação de dimensões e categorias durante o processo da pesquisa. Neste trabalho, o interesse de pesquisa foi investigar a interpretação que os próprios sujeitos participantes da orientação tinham da situação sob estudo, descrevendo-se as características dos fenômenos, objetivando compreender o significado dos aspectos inerentes à relação orientador-orientando.

\subsection{Técnicas e procedimentos}

Com relação às técnicas e procedimentos empregados para a coleta de dados, com o intuito de materializar os objetivos da pesquisa e fundamentar os conceitos aqui utilizados, foram realizadas pesquisa bibliográfica e entrevistas.

A pesquisa bibliográfica foi desenvolvida utilizando-se artigos científicos publicados em periódicos nacionais e internacionais, anais de congressos, páginas da internet, livros, teses e dissertações que versavam sobre a temática de orientação.

As entrevistas foram realizadas com orientadores e orientandos dos programas de pósgraduação stricto sensu em Contabilidade da cidade de São Paulo. Escolheu-se este tipo de instrumento de investigação empírica em função das questões a serem pesquisadas estarem diretamente relacionadas à percepção, experiência e opinião dos entrevistados sobre elementos da relação orientador-orientando, admitindo-se a possibilidade de o investigador 
interrogar individualmente cada entrevistado, tornando possível o esclarecimento de dúvidas, tanto em relação às perguntas, quanto às respostas, bem como a possibilidade de aprofundamento em respostas relevantes sobre a temática investigada.

Outros pontos observados que reforçaram a opção pelas entrevistas foram a oportunidade de avaliação das atitudes dos entrevistados através do registro de reações e gestos destes sujeitos durante a investigação; a oportunidade de obtenção de dados relevantes que não se encontravam em fontes documentais; a possibilidade de se conseguir informações mais precisas, podendo-se comprovar discordâncias; a oportunidade de verificar a validade das descrições através da coerência das respostas dos entrevistados; e por se considerar a entrevista como uma técnica eficaz para a revelação de assuntos complexos, de opiniões e sentimentos (SELLTZ et al., 1974).

Visando facilitar o processo de interpretação, descrição e análise dos dados, utilizaram-se entrevistas semi-estruturadas. Foram elaborados dois roteiros de entrevistas: um para os orientandos e outro para os orientadores, cujas cópias encontram-se no Apêndice 1 deste trabalho. Contudo, mesmo seguindo-se roteiros semelhantes de entrevista para cada orientando e orientador investigado, procurou-se garantir uma certa flexibilidade - os sujeitos foram incentivados a manifestar explicações e aprofundamentos em questões de maior interesse. A estratégia utilizada para elevar o grau de profundidade da entrevista foi a ênfase nos sentimentos e a busca por relatos descritivos e comparativos de situações vividas pelos sujeitos no processo de relacionamento orientador-orientando, pois segundo Kerlinger (1981, p.30), “[...] o entrevistador pode, por exemplo, depois de fazer uma pergunta oral, sondar as razões das respostas dadas: uma das vantagens da entrevista é, então, sua profundidade.” 
Buscando garantir a idoneidade da investigação, procurou-se, na condução das entrevistas: explicar as questões para os entrevistados; minimizar a influência do pesquisador mantendose um clima agradável e dando-se liberdade para que os sujeitos fossem estimulados a apresentar francamente as suas opiniões; agendar antecipadamente as datas e horários dos encontros das entrevistas, por meio de contato telefônico ou correio eletrônico; declarar a garantia do sigilo dos nomes dos participantes; além disso, efetuou-se o registro integral das respostas, por meio de fitas cassete, com posterior transcrição, o que permitiu que nenhum dado das conversas fosse perdido, proporcionando precisão e confiabilidade aos achados.

\subsection{Sujeitos da entrevista}

Para responder às questões descritas no roteiro de entrevistas, foram entrevistados mestrandos e doutorandos na condição de alunos orientandos; doutores e mestres que já foram orientandos; e professores orientadores dos programas de pós-graduação stricto sensu em Contabilidade, da cidade de São Paulo, compreendendo os programas da USP, PUCSP e FECAP. As entrevistas foram realizadas no ambiente dessas instituições durante os meses de outubro, novembro e dezembro de 2003. As descrições das características dos sujeitos entrevistados encontram-se no Apêndice 2 deste trabalho.

Quanto ao número de sujeitos entrevistados, não foram utilizados critérios de amostragem probabilística. Esta escolha se deu de forma intencional. Segundo Duarte (2002, p. 143-144), numa metodologia de base qualitativa, o número de sujeitos que virão a compor o quadro das entrevistas dificilmente poderia ser determinado a priori, pois há uma dependência da qualidade das informações obtidas em cada depoimento, assim como da profundidade e do 
grau de recorrência e divergência dessas informações, “[...] enquanto estiverem aparecendo dados originais ou pistas que possam indicar novas perspectivas à investigação em curso, as entrevistas precisam continuar sendo feitas." Foram entrevistados vinte e dois sujeitos, sendo sete orientadores e quinze orientandos.

\subsection{Pré-teste do roteiro de entrevistas}

Como forma de se ter indicadores de validade do instrumento de coleta de dados, foram realizados pré-testes com dois orientandos e um orientador do programa de pós-graduação em Contabilidade da USP. A análise do roteiro de entrevista evidenciou algumas falhas que poderiam ocorrer na execução das entrevistas, tais como a inconsistência e complexidade de algumas questões, que não foram entendidas pelos sujeitos do pré-teste. Assim, o roteiro de entrevistas foi reformulado, seguindo as recomendações de Marconi e Lakatos (2003, p.203):

a) Quanto à fidedignidade das respostas: procurou-se analisar se a aplicação das entrevistas, para sujeitos diferentes, teria os mesmos resultados;

b) Observou-se o critério de validade, verificando se o roteiro fornecia os dados necessários para responder aos objetivos e ao problema de pesquisa;

c) Operatividade: foi também verificado se as perguntas eram claras e de fácil entendimento pelos sujeitos.

Destaca-se ainda que as entrevistas do pré-teste do roteiro de entrevistas não foram utilizadas na análise geral dos dados, uma vez que foi necessária alguma mudança nesse instrumento de coleta de dados, descrita anteriormente. 


\subsection{Limitações do estudo}

Foram observadas as seguintes limitações neste estudo:

Os resultados não podem, nem devem, ser generalizados, tendo em vista o reduzido número de sujeitos pesquisados, por se utilizar amostragem intencional. Mattar (1996, p.269) acredita que as “[...] técnicas não probabilísticas não invalidam uma pesquisa, pois a amostragem probabilística é tecnicamente superior na teoria, e na prática surgem alguns problemas de aplicação que enfraquecem a sua superioridade.” Entretanto, os dados coletados e analisados serviram para compreender a realidade das instituições e dos sujeitos em análise.

Outra limitação diz respeito ao que foi pesquisado junto a estes sujeitos. Em função da amplitude dos assuntos que cercam a orientação na pós-graduação, não se investigou a história de vida e trajetória acadêmica dos orientandos e orientadores, restringindo-se a pesquisa aos aspectos da relação orientador-orientando no ambiente da pós-graduação.

Por se tratar de uma pesquisa qualitativa, assume-se a limitação de que a característica do método utilizado é a subjetividade.

Outra limitação apontada é que não foram registrados nem analisados gestos e reações do entrevistador, que procurou manter uma interação imparcial com os entrevistados, com vistas a não influenciar a descrição dos seus relatos. Todavia, gestos e reações dos entrevistados foram sistematicamente observados e registrados. 
Este capítulo descreveu os caminhos metodológicos que nortearam o desenvolvimento deste trabalho. Apresentou e fundamentou a opção da pesquisa qualitativa pela utilização de entrevistas semi-estruturadas. Além disso, discorreu sobre os critérios de escolha dos participantes das entrevistas, a elaboração de pré-teste para obter indicadores de validade do roteiro de entrevistas e as limitações observadas neste estudo. Com a finalidade de atingir os objetivos e responder ao problema de pesquisa, apresenta-se, no capítulo a seguir, a descrição e análise dos resultados da investigação empírica com orientadores e orientandos dos programas de pós-graduação em Contabilidade da capital paulista. 


\section{APRESENTAÇÃO E ANÁLISE DOS RESULTADOS}

O propósito deste capítulo é descrever e analisar os dados oriundos das entrevistas, norteandose pela metodologia escolhida, fazendo-se ligações com o referencial teórico apresentado no Capítulo 2 deste trabalho.

\subsection{Análise das entrevistas}

Conforme explicitado no Capítulo 3, optou-se por conduzir a investigação empírica utilizando-se entrevistas. Cada entrevista foi iniciada com a apresentação do pesquisador, mesmo tendo feito um contato telefônico anterior, com a exposição dos objetivos da pesquisa, ressaltando que se tratava de uma dissertação de mestrado. Foi colocado também que a entrevista seguiria um roteiro previamente estabelecido, o qual fora apresentado por escrito a todos os sujeitos, com o intuito de situá-los e direcionar as suas respostas. Procurou-se também garantir flexibilidade no roteiro de entrevistas, de modo que pudessem ser acrescentadas questões para enriquecimento da análise.

Durante a realização das entrevistas, os orientandos se sentiram à vontade para descrever as suas experiências e manifestar as suas opiniões sobre a relação com os orientadores. Não foi percebido receio de represália por parte dos respectivos orientadores para com estes orientandos, uma vez que fora garantido o anonimato da identificação dos participantes da investigação, o que também facilitou a fluidez para obtenção de informações relevantes.

Ressalta-se que não foi informado aos orientadores que os seus respectivos orientandos iriam participar desta entrevista. Optou-se em não comunicá-los, pois, se os orientandos soubessem 
que seu orientador havia sido comunicado sobre a entrevista, poderia ter sido introduzido um viés nas respostas desses orientandos, que talvez tivessem medo de tocar em pontos problemáticos do relacionamento orientador-orientando. Observa-se também que não existiu uma correspondência entre a lista de orientadores e de orientandos, ou seja, pode ter feito parte da amostra algum orientando sem o seu respectivo orientador e vice-versa.

Na análise dos dados, procurou-se criar categorias de análise (MINAYO, 1995; SELLTZ et al., 1974), agrupando-se respostas idênticas de sujeitos diferentes, observando-se também casos em que a fala do sujeito, quando tocava em vários pontos diferentes, permitia a identificação de mais de uma categoria.

Buscando-se um melhor entendimento, dividiu-se a análise das entrevistas em quatro agrupamentos (áreas temáticas), em concomitância com os objetivos específicos da pesquisa, descritos no Capítulo 1 deste trabalho.

No agrupamento 1, foram identificados aspectos que levam os alunos a escolherem os orientadores, bem como as condições e requisitos colocados pelos orientadores para esta escolha.

Com relação aos fatores que levam os orientandos a escolherem os orientadores, foram identificadas quatro categorias, segundo as respostas dos orientandos:

1) A escolha do professor orientador se deu pela congruência de interesse de pesquisa em determinado assunto, ou em determinada linha de pesquisa (10 respostas). De certa forma, o aluno candidato à orientação passou a investigar os interesses de pesquisa do professor e 
as pesquisas por ele já executadas para fazer a sua escolha. Alguns relatos descritos a seguir ilustram esta categoria:

\begin{abstract}
No meu caso, foi dado ao interesse e coincidência das linhas de pesquisa. Em determinado momento eu tomei conhecimento que o professor $\mathrm{X}$ tinha interesse em desenvolver pesquisas na área de comunicação. Como eu estava trabalhando este tema na disciplina Teoria da Contabilidade, me dirigi a ele e apresentei a idéia. Ele gostou da idéia e este foi o ponto inicial de tudo. (Orientando 15)
\end{abstract}

Na verdade foi a área de atuação dele, não tive disciplinas com ele, mas como o meu interesse estava voltado para a área pública, e ele era o único que pesquisava este tema aqui na escola, tive conhecimento das publicações, do trabalho que ele vem desenvolvendo, daí entrei em contato e ele me aceitou como orientando. (Orientando 3)

2) O interesse do aluno na mesma linha de pesquisa do professor, apesar de óbvio, em princípio, fora delineado em função de alguma experiência anterior do aluno com o professor, por meio de alguma disciplina, projeto de pesquisa, o que acabou causando esta compatibilidade de interesses (8 respostas). As declarações abaixo ilustram esta categoria:

Eu cursei a minha primeira disciplina no mestrado com o professor X, o que me fez escolhê-lo como meu orientador, porque a sua tese de doutoramento tinha sinergia com o que eu estava querendo pesquisar no mestrado. (Orientando 10)

O fator principal foi que eu já havia trabalhado com a professora no programa de apoio ao ensino da USP, e acabei gostando, porque ministra aulas em uma das áreas que tenho interesse. Então, este foi o início da orientação. (Orientando 12)

3) Aliado às duas categorias anteriores, os orientandos mencionaram que um fator preponderante na escolha dos orientadores foi a empatia e a afinidade pessoal com os mesmos, delineadas da própria experiência que o aluno teve no contato com o professor (7 respostas), compatibilizando com as pesquisas de Fernandes et al. (1993), Freitas e Zawislak (2003), Berndt (2003), Martins (1997) e Luna (1983), nas quais os autores observam a empatia como fator chave de sucesso no relacionamento entre orientador e orientando. No entanto, os orientandos não relataram se fizeram investigações mais apuradas que verificassem o perfil do professor nem tão pouco análise das suas características pessoais. Os próximos relatos exemplificam esta categoria:

[...] Os fatores que me levaram a escolher o orientador foram a afinidade na área de conhecimento e a empatia, conseguida quando fui aluno dele e quando fiz programa de apoio ao ensino com ele.
Excluído: O que me levou a escolher o orientador foi o interesse nosso pela mesma linha de pesquisa, pois já tinha lido alguma coisa dele, gostei, entrei e contato e escolhi como meu orientador. (Mestrando 2)
Excluído: Eu já tinha experiência com ele, pois foi o meu orientador no mestrado, e este foi o principal fator da minha escolha. (Doutor 1)ף 
Eu penso ser importante o aluno ser bem vindo para a orientação de alguém que você se sinta mais à vontade, do que, sei lá, pedir para alguém que não está a fim de te orientar ou que não vai muito com a sua cara e você tem que provar tudo de novo! (Orientando 14)

Primeiro a intimidade, conhecimento do tema e da metodologia a ser adotada e o interesse pela linha de pesquisa. Mas, o fator preponderante, foi a empatia dos dois lados, já que tinha feito uma disciplina Teoria das Finanças e participado de artigos com ele, e desta vivência, acabei escolhendo-o como orientador. (Orientando 9)

4) De forma contrária às demais categorias, dois orientandos de uma instituição particular relataram que a escolha do orientador fora feita pela própria instituição, o que não foi percebido nas demais instituições, nas quais o aluno é quem escolhe o orientador, segundo os relatos a seguir:

Não fui eu quem escolheu o orientador. A instituição é que escolhe, indicando três nomes de possíveis orientadores, em função da quantidade de orientandos que cada um tem, daí me direcionaram para um determinado professor. Então não foi bem uma escolha minha. (Orientando 8)

Bom, na verdade o sistema de escolha aqui é um pouco diferente! O aluno não escolhe, apenas sugere o orientador e depois a coordenação do curso que indica em função da disponibilidade e interesse do professor com a sua pesquisa. Então, na verdade, meu orientador foi escolhido pela coordenação do curso. (Orientando 11)

Nesta categoria, ao coletar o relato destes sujeitos (Orientando 8 e 11), foi percebida a manifestação de expressões de insatisfação e ironia durante a entrevista, denotando a desaprovação com relação ao processo de indicação do orientador pela instituição, confirmando as observações de Eco (1998) sobre a não adequação dos orientadores aos temas de pesquisa dos orientandos.

Com relação às condições e requisitos colocados pelos orientadores para aceitação dos orientandos, foram estabelecidas quatro categorias, conforme o depoimento dos alunos:

1) Os orientandos encararam a escolha como um processo natural, uma vez que o conhecimento e relacionamento anteriores com os professores fizeram com que os orientadores pudessem avaliar e fazer seus julgamentos dos alunos, fazer as suas escolhas, 
não colocando formalmente, de maneira explícita, condições e requisitos para isto (5 respostas). Alguns depoimentos ilustram esta categoria:

\begin{abstract}
Praticamente nenhuma, pois já me conhecia das disciplinas e sabia quem era eu. Acredito que já tinha uma boa noção da minha pessoa como aluno e a estendeu para a orientação. Eu penso que não tiveram condições formais. (Orientando 14)

[...] assim, porque ele já me conhecia de dentro da sala de aula, acho que foi mais um casamento de propostas do que algo que tenha colocado como pré-requisitos para aceitar-me ou não. (Orientando 1)
\end{abstract}

Foi assim uma coisa tão natural! Acho que ele já vinha conhecendo a minha forma de trabalhar e conhece as minhas características. Não existiu nenhuma formalidade para aceitar-me ou não. (Orientando 4)

2) Outros orientandos relataram que o principal requisito colocado pelo orientador foi “pesquisar o que ele quer, um tema que ele estivesse disposto a orientar”, configurando-se o orientador como um direcionador do processo, iniciando-se uma relação de autocracia, confirmando as observações de Martins (1997) - cada professor desempenha a função de orientador da sua maneira; Severino (2002) - a relação deveria ser de aprendizagem, não de autocracia; Luna (1983), Moses (1984), Brown e Adkins (1998), Piccinin (2003), Warde (1997) e Lehmann (2001) - caráter autocrático da orientação, no qual o professor é um direcionador do processo, para não perder o controle. Os relatos abaixo demonstram esta categoria:

\footnotetext{
Primeiro requisito foi pesquisar o que ele quer, o que ele acha que é relevante. Quando cheguei no mestrado, já tinha uma idéia do que pesquisar, mas, segundo ele, existiam coisas mais prioritárias que deveriam ser pesquisadas. Já no primeiro encontro ele não aceitou o meu tema, depois conversamos muito e eu acabei aceitando o tema sugerido por ele. (Orientando 2)

Primeiramente se o tema da pesquisa estivesse de acordo com a linha de pesquisa dela e nos seus interesses de orientação. Como não estava, ela acabou direcionando-me para um tema de seu interesse. (Orientando 7)
}

Ao responderem esta questão, os sujeitos manifestaram feições e gestos de desaprovação com relação à atitude impositiva dos orientadores. Além dos indícios de relações autocráticas, a questão de direcionar o processo e a pesquisa para os meandros e domínios de saberes dos
Excluído: Além de o orientador ser escolhido pela instituição, ele não colocou requisitos para me aceitar como orientando, pois fora professor em uma disciplina do curso e me conhecia! (Mestre 4) ๆ

Excluído: A questão do tem que estava sendo discutido sugerido por ele, além de dedicação para fazer a pesquisa nesta área. (Mestre 3) ๆ 
orientadores poderia estar relacionada com as observações de Martins (1994) - “fraqueza intelectual dos orientadores”, e Haguette (1994) - “incompetência metodológica do orientador”, pois foi notada uma rejeição, por parte dos orientadores, aos temas que estão fora dos seus interesses. Quando agem desta forma, destituem-se do seu papel de educador e do desafio de, juntamente com o orientando, buscar coisas novas. Este ponto reflete uma má vontade, medo, incompetência ou até um total desentendimento do que é orientar e do papel do orientador como educador. Ressalta-se também que não foram encontrados relatos de problemas de relacionamento que foram contornados após uma conversa franca e aberta entre orientador e orientando.

3) Outra categoria verificada foi a preocupação dos orientadores com a dedicação dos alunos com as atividades do programa de pós-graduação: disciplina na confecção dos trabalhos, procurar fazer um trabalho de qualidade e cumprir os prazos (8 respostas). Entretanto, não explicitaram como alcançar esta qualidade nem o que seria um trabalho de qualidade, talvez por desconhecimento dos padrões exigidos. Esta categoria vai ao encontro das observações de Berndt (2003), Santos Filho e Carvalho (1991), Carvalho (1994), nas quais os autores relatam o desconhecimento dos parâmetros pelos sujeitos componentes da pósgraduação e a falta de conscientização do que é uma dissertação, resultando em problemas e dificuldades de diversas ordens. Os próximos relatos ilustram esta discussão:

[...] explicitamente ele colocou a questão da disciplina na confecção dos trabalhos, cumprimento dos prazos, organização e principalmente ter a criatividade e vontade de fazer um trabalho. (Orientando 9)

Um trabalho de qualidade é o que ele sempre tem frisado para mim [...] e para isso é necessário leituras, comprometimento com prazos, cronogramas, mas, além de obedecer aos prazos e cronogramas da universidade, ele não impôs nenhuma condição. (Orientando 6)

Esta categoria poderia estar também relacionada à preocupação dos orientadores, dos coordenadores dos programas de pós-graduação e da CAPES com as evasões e desistências

Excluído: [...] pediu comprometimento, fazer um trabalho de qualidade e ele também falava para eu caminhar com a tese, porque o tempo e o prazo estavam caminhando contra mim. (Doutor 1) ๆ 
provocadas pela perda dos alunos devido à não observância dos prazos, talvez da própria experiência passada destes professores com este fato, e das pressões exercidas pela CAPES quanto ao tempo de titulação, quantidade de titulados e indicadores de evasão dos programas. Estes aspectos ratificam os estudos de Cunha (1991), Hipólito (2003), Beiguelman (1998), Durham e Gusso (1991) e Fernandes (1993), nos quais os autores criticam a questão do achatamento dos prazos e a sua influência no desempenho dos alunos dos programas.

Os relatos mostram indícios de que os professores, pressionados por estes indicadores, estariam transferindo esta responsabilidade ao aluno, exigindo trabalhos de qualidade, cumpridos dentro dos prazos estabelecidos, o que poderia provocar problemas no relacionamento orientador-orientando e no aluno, conseqüências tais como o desligamento e prolongamento do tempo de titulação. Observou-se também que os orientadores atribuem uma sobrecarga de responsabilidade pela conclusão dos trabalhos para os alunos, enfatizando o cumprimento dos prazos em detrimento de uma assistência maior ao orientando, o que poderia gerar problemas de relacionamento, segundo o depoimento a seguir:

Ele também falava para eu caminhar com a tese que o tempo estava se passando, me deixou muito à vontade para definir o tema, problema, mas foi muito rigoroso com a questão do prazo. (Orientando 13)

Esta atitude dá idéia de que este fator exógeno ao programa de pós-graduação - pressão exercida para cumprimento de prazos cada vez mais rígidos - apresenta-se como uma sugestão indireta e lamentável de se reduzir a exigência de um trabalho de alto nível, enfatizando-se a quantidade e o tempo em detrimento à qualidade das dissertações e teses dos programas. Castro (2002, p.112), nas suas manifestações sobre os prazos, destacou desequilíbrios de tempo nas diversas etapas dos cursos de pós-graduação, destacando que “[...] se muito tempo for despedido freqüentando-se aulas, fazendo disciplinas ou coletando-se dados, fatalmente faltará tempo para análise, a escrita e a revisão do trabalho de dissertação 
ou tese.” Para o autor, a qualidade do trabalho tem ligação com o tempo utilizado para analisá-lo sob uma perspectiva com espírito crítico, decorrente de uma fase de análise e revisão do material. Neste sentido, o trabalho poderia ser mais bem articulado e defendido, tendo um ganho de qualidade. Verifica-se, ainda, que em função das características do processo avaliativo dos programas, orientadores têm assumido posições de controladores, vendo-se os orientandos obrigados a conciliar e fundir tempos institucionais no tortuoso caminho que conduz ao cumprimento dos prazos.

4) Embora preocupante, também relacionada com as categorias anteriores, somente três sujeitos manifestaram que o professor colocou como requisito um projeto de pesquisa formal, sendo que este, se aceito fosse, seria discutido por orientador e orientando. Possivelmente esta categoria estaria relacionada com a dificuldade do aluno em definir um tema, já que, na maioria dos casos, não fora requisitado o projeto, mas a compatibilidade de interesses entre orientador e orientando, corroborando as observações de Correa (1984) sobre a importância da escolha do tema; de Tunes (1981), quanto aos problemas dos alunos por não saberem desenvolver atividades de pesquisa; e de Loui (2003) sobre o que é uma pesquisa e como os sujeitos deveriam se ajudar nesta situação. Os relatos dos orientandos exemplificam esta categoria:

\footnotetext{
[...] outra coisa foi a elaboração do projeto de pesquisa. A escola não tem a cultura de trabalhar o projeto de pesquisa formalizado, mas o orientador pensa que isto é essencial, e que vai proporcionar sucesso na dissertação: o planejamento da pesquisa. (Orientando 2)

Primeiramente que o tema da minha pesquisa estivesse de acordo com a linha de pesquisa dela, para que pudesse me orientar e depois que eu tivesse um projeto de pesquisa, formalizado e definido sobre o meu tema de escolha. (Orientando 7)
}

Apesar de os orientadores colocarem como requisito para aceitação do orientando a avaliação do projeto de pesquisa deste, observou-se que não existe a cultura do projeto de pesquisa formal nos três programas analisados. Segundo investigação feita com os coordenadores do 
programa da USP e FECAP, o processo seletivo dá maior ênfase aos resultados do teste da ANPAD - Associação Nacional dos Programas de Pós-graduação em Administração - no teste de conhecimentos específicos e na entrevista, figurando o projeto apenas como um requisito pró-forma no processo seletivo.

Em contato telefônico com o programa da PUCSP, observou-se que o processo seletivo difere dos demais programas apenas por não estar afiliado ao teste da ANPAD, contudo são feitos testes de conhecimentos específicos e análise de entrevistas, bem como a apresentação de um pré-projeto de pesquisa.

Com base nestas investigações, verificou-se que o processo seletivo dos programas destaca a confecção de um projeto informal ou pré-projeto de pesquisa. Porém, não há o devido peso deste projeto no processo seletivo, figurando apenas como um requisito pró-forma. Nota-se que, quando o orientando se apresenta ao orientador, parte-se praticamente do zero, fazendo a escolha da temática, da metodologia e do levantamento bibliográfico.

Ainda com relação às condições e requisitos, na visão dos orientadores, foram evidenciadas três categorias, a seguir descritas:

1) Assim como os orientandos, os orientadores verificaram o interesse do aluno na linha de pesquisa em que atuam, mediante um projeto de pesquisa. Não relataram, contudo, se houve uma exigência de formalidade no projeto de pesquisa, mas que o seu julgamento foi feito com base na compatibilidade de interesses de pesquisas entre orientandos e orientadores (6 respostas). Os relatos seguintes ilustram esta categoria:

Primeiro pré-requisito é que o aluno tenha interesse em pesquisar o que eu estou pesquisando. Caso afirmativo, vejo o projeto de pesquisa do mesmo, discuto e chegamos a um termo para começar a orientação. (Orientador 1) 
Que o aluno esteja envolvido no programa e queira pesquisar dentro da minha área de atividades, na linha que pesquiso e estudo (Orientador 4)

O primeiro ponto seria o interesse do assunto do aluno, se a sua proposta estaria dentro da minha linha de pesquisa. Isto para mim é fundamental!. (Orientador 6)

2) Relacionada com a categoria anterior, dois orientadores relataram que, além de verificar a compatibilidade de interesses, avaliam, pelo projeto de pesquisa, os conhecimentos do aluno em metodologia da pesquisa, conforme exemplificam alguns relatos:

[...] que o tema da pesquisa esteja dentro da minha área de interesse, segundo quando eu percebo que o aluno tem potencial para fazer um bom trabalho, que o aluno conhece metodologia da pesquisa, de preferência um ótimo trabalho. Esse potencial eu já percebo quando eu peço ao aluno uma colocação do problema, dos objetivos e do método da pesquisa. Por estes tópicos, eu percebo se irá conseguir um bom trabalho! (Orientador 5)

Primeiramente, que os alunos estejam dentro da minha linha de pesquisa e dentro da minha área de interesses e, em segundo lugar, que tenha um bom projeto de pesquisa aprovado pelo departamento, no qual verifico a capacidade de metodologia de pesquisa do aluno. (Orientador 7)

3) Por outro lado, apenas um professor colocou como requisito, além das categorias descritas anteriormente, uma avaliação da capacidade de lidar com o aluno (empatia), e se este teria disponibilidade e motivação para com uma pesquisa em nível de pós-graduação, conforme o depoimento abaixo:

Uma outra coisa é a facilidade de lidar e da disponibilidade do aluno, é uma coisa que pode ser subjetiva, mas na minha cabeça não é, eu gosto de ter várias reuniões com os alunos [...] Um outro requisito é que o camarada esteja disposto e motivado com o tema da pesquisa, que tenha disposição e animação diante da pesquisa [...] (Orientador 2)

As categorias elencadas pelos professores dão indícios de que eles não fizeram uma análise prévia das características pessoais dos alunos candidatos à orientação. A tendência dominante foi a verificação da compatibilidade de interesses pelo projeto de pesquisa e uma preocupação em selecionar alunos com conhecimentos em metodologia de pesquisa.

As respostas dos orientadores e orientandos coadunam-se com as categorias de compatibilidade de interesse nas linhas de pesquisa e uma preocupação em direcionar o aluno 
às ambições de pesquisa do professor. A experiência técnica e profissional e o contato anterior dos sujeitos foram apontados como fatores delineadores da empatia. Entretanto, nas escolhas e na colocação de requisitos, não foram verificados indícios de análise de compatibilidade pessoal entre os sujeitos (somente um orientador mencionou este aspecto), pois o relato dos orientadores indicou que há uma preferência de escolha de projetos de pesquisa, da capacidade técnica e metodológica e não das características afetivas e de personalidade dos alunos. Já os alunos têm uma preocupação maior em estabelecer laços afetivos em contatos anteriores, além da compatibilidade de interesses já relatada. Estes resultados, a princípio, mostram que os orientadores teriam uma tendência de escolher os projetos de pesquisa e não os alunos.

Indica-se, como possível solução para a ausência de conhecimentos em metodologia de pesquisa, a utilização da figura do co-orientador e utilização da modalidade de orientação coletiva. Observou-se que, tanto por parte dos orientadores como dos orientandos investigados, houve uma preocupação com conhecimentos em metodologia de pesquisa como um dos fatores condicionantes à qualidade dos trabalhos. Desta maneira, o modelo de orientação coletiva poderia auxiliar na solução de problemas como a ausência de conhecimentos metodológicos de pesquisa por parte do orientando e do orientador.

Como relatado na discussão teórica de Santos Filho e Carvalho (1991) e Garcia e Alves (2002), o co-orientador poderia contribuir para que a dissertação ou tese tivesse uma pluralidade de visões teóricas e metodológicas, melhor tratamento do tema analisado e, conseqüentemente, um ganho de qualidade. Porém, verificou-se que, nos três programas analisados (USP, PUCSP e FECAP), inexiste a figura do co-orientador e que ainda não há a prática da orientação coletiva. 
No agrupamento 2, foram identificados, descritos e analisados fatores comportamentais, técnicos e de conhecimento que permeiam a relação orientador-orientando.

No que diz respeito aos fatores comportamentais que facilitam a relação, para os orientandos foram elencadas as seguintes categorias:

1) A acessibilidade, disponibilidade e atenção do orientador para as tarefas de orientação, maior proximidade com os orientandos (10 respostas). Esta categoria é concomitante com as observações de Berndt (2003), Maher (1996), Frame e Allen (2002), Dong (1998), Fernandes et al. (1993), nas quais os autores asseveram que o contato periódico e a acessibilidade entre os sujeitos são fatores de sucesso na relação orientador-orientando e na conclusão dos trabalhos. Os relatos a seguir ilustram esta categoria:

\begin{abstract}
Conseguir comunicar-se com o seu orientador, a acessibilidade, nós conseguimos falar coisas muito próximas, a proximidade. Você conseguir estar próximo do seu orientador, ter uma real orientação, não uma orientação virtual, debater periodicamente o que você encontrou, quais as dificuldades que você está tendo na pesquisa. (Orientando 2)

Acredito que ele é bem disponível no sentido em que sempre vou procurá-lo, ele me atende bem, dentro do tempo que ele tem procura me atender, não fica querendo que eu fale rápido, me dá toda atenção que peço, é bastante acessível e atencioso, encaro isso como um fator que facilita a nossa relação. (Orientando 5)
\end{abstract}

2) Outra categoria elencada foi o "orientador conhecer as características pessoais do orientando”, advindo dos contatos anteriores estabelecidos por estes sujeitos (7 respostas), o que corrobora as observações de Severino (2002) e Warde (1993), as quais consideram que o trabalho do orientador transcende os limites da orientação. Os depoimentos abaixo exemplificam esta categoria:

[...] acho que ele conhecer o meu processo de trabalho, a minha forma de funcionar, ele percebe que estou levando o trabalho a sério, vê também as minhas dificuldades, isso faz com que tenha confiança. (Orientando 4)

[...] durante o tempo, aos poucos fomos trabalhando juntos, ele me chamava para os projetos de treinamento, ou seja, fomos criando laços de compromissos profissionais e ao mesmo tempo
Excluído: O que posso dizer que facilitou é que nós tínhamos uma relação muito próxima no início da orientação, e os primeiros contatos que tivemos me deixaram muito esperançoso (Mestre 3)ף

I

Excluído: O orientador conhecer o orientando é algo muito importante, pois ajuda a entender os problemas pelos quais o aluno está passando, bem como sua

forma de trabalho. (Mestrando 1) ๆ 
pessoais, você vai conhecendo a pessoa, vai sabendo como falar, como se expressar e aos poucos a relação foi se desenvolvendo de forma a facilitar as coisas. (Orientando 12)

3) Relacionando-se com as categorias anteriores, quatro orientandos relataram que a confiança no orientador é um dos fatores que facilitam a relação orientador-orientando, evidenciada nos seguintes relatos:

\begin{abstract}
Uma relação de confiança, acima de tudo, de responsabilidade de cumprimento do dever. Baseado nesta confiança, o meu orientador foi um canal, no qual consegui estímulos para começar a produzir trabalhos científicos de uma maneira mais intensa. (Orientando 15)

[...] o que facilita: confiança, existe confiança de entendimento de como é o meu processo de trabalho. (Orientando 4)
\end{abstract}

4) A facilidade de comunicação entre os sujeitos foi também evidenciada como uma categoria, apesar de ser relatada por apenas dois orientandos. Este aspecto relaciona-se com a categoria acessibilidade e é evidenciada nas pesquisas de Fernandes et al. (1993), Santos (1988), Freitas e Zawislak (2003) e Piccinin (2003). Os seguintes depoimentos ilustram esta categoria:

[...] linguagem: conseguir entender e comunicar-se com o seu orientador, o modo de agir e tratar as pessoas é muito importante. Acho fundamental essa abertura de poder chegar para ele e dizer que estou com um problema aqui, ali, um problema na minha casa, abertura para compreender o que está acontecendo na sua vida naquele momento, para ele relacionar isso com a produtividade ou não no processo de elaboração da dissertação.

(Orientando 2)

[...] uma boa convivência e muito diálogo entre as partes. Na verdade a relação não é fácil: duas pessoas tentando chegar a um mesmo objetivo, pensando de maneira diferente [...] Acho que o principal fator comportamental é o diálogo. (Orientando 3)

Percebe-se que apenas dois dos orientandos entrevistados enfatizaram a questão da facilidade de comunicação como um fator facilitador do relacionamento. Por se tratar de uma relação interpessoal, na qual se poderia trabalhar de forma construtiva as diferenças de opiniões, ideologias, métodos de trabalho e conduta, dever-se-ia considerar o fator comunicação como um dos pontos chave para o sucesso do relacionamento entre orientadores e orientandos. Observa-se que não adianta o orientador ter tempo disponível se o orientando não consegue comunicar, fazer entender a sua mensagem.
Excluído: [...] Outra coisa que facilita é o conhecimento amplo dele, acaba tendo condição de me orientar mais neste sentido, acabo sentindo confiança nele, por ter este conhecimento mais amplo. (Mestrando 5) ๆ 
Ainda quanto aos fatores comportamentais que facilitam a relação, pela resposta dos orientadores, foram diagnosticadas as seguintes categorias:

1) Os orientadores foram unânimes quanto ao interesse e comprometimento do orientando com as atividades do programa, exemplificado nas descrições:

Vejo como um dos maiores problemas do programa a dedicaça do aluno em fazer todas as a
que devem ser cumpridas. (Orientador 4) Primeiramente vejo que o orientando deveria estar imbuído do desejo, comprometimento forte de fazer o trabalho de alto nível. (Orientador 5)

O aluno necessita ter espírito de pesquisador, e não se preocupar somente com os conteúdos das disciplinas, e ir embora. Deve ter comprometimento. (Orientador 7)
Excluído: Acho que um fator que facilita é o comprometimento, tanto do orientador como do orientando. (Professor 3) I

2) Relacionada com a categoria anterior, dois orientadores relataram a questão da empatia como um fator facilitador, relacionando-se com as observações de Henriques e Medeiros (1999). Os autores observam que a afabilidade aliada à empatia é de suma importância para um clima amigável entre os sujeitos, o que provocaria uma maturidade intelectual nos orientandos. As observações abaixo ilustram esta categoria:

\footnotetext{
O grande problema da relação está no entendimento das duas pessoas, se estão interessados e se há uma compatibilidade de gênios, da maneira, da forma, dos procedimentos do orientador. É isso que dá um casamento interessante. Quando não tem compatibilidade de gênios, fica muito difícil. (Orientador 1)

Como é uma relação de longo prazo, há necessidade de uma certa empatia entre orientador e orientando, que haja uma comunhão de interesses, pois é um trabalho em conjunto e tem uma coautoria do orientador. (Orientador 6)
}

3) Além do comprometimento e da empatia, apenas um orientador respondeu que considera como fator facilitador o respeito mútuo e a confiança de ambas as partes, relacionamento franco e transparente, relatado na seguinte descrição:

[...] eu diria que a transparência, franqueza, e um pouco de confiança, acho que esta relação só funciona quando existe confiança. Em algumas situações, você acaba notando que existe alguma desconfiança, eventualmente algumas preocupações com respeito a algumas linhas de pensamento, acho que tem que ter uma relação de confiança. (Orientador 2) 
Fazendo-se um comparativo das categorias elencadas pelos sujeitos, verifica-se que, na opinião dos orientadores, o principal fator comportamental que facilitaria a relação orientador-orientando é o comprometimento do aluno, sendo que, na resposta dos orientandos, não foi identificada esta categoria. Do lado dos orientandos, foi identificada a categoria de acessibilidade do professor orientador aliada ao conhecimento prévio da pessoa do aluno, o que também não foi relatado pelos orientadores. Percebeu-se que os orientadores buscam alunos comprometidos com as atividades do programa e os orientandos buscam segurança nos orientadores, evidenciada em metodologia de pesquisa e em conhecimento específico da área.

Por outro lado, foram identificadas categorias comuns entre os orientadores e orientandos, o respeito e a confiança ( 1 orientador e 4 orientandos) e a empatia ( 1 orientador e 1 orientando), como aspectos comportamentais que facilitariam a relação, compatibilizando-se com os estudos de Fernandes et al. (1993), Freitas e Zawislak (2003), Berndt (2003) e Martins (1997) que citam a empatia como um fator facilitador.

Quanto aos fatores comportamentais que dificultam a relação, para os orientandos foram identificadas quatro categorias, descritas como segue:

1) A falta de contato, a inacessibilidade, refletidas na falta de tempo dos professores para com as atividades de orientação (9 respostas), ratificando os estudos de Martins (1997), Luna (1983), Santos Filho e Carvalho (1991), Bianchetti e Machado (2002), Severino (2002), Rodrigues Jr. et al. (1993), Vasconscellos (1981), Berndt (2003), Castro (2002), Pereira et al. (2002), Santos (1988), Godoy et al. (2000), nos quais os autores observam o pouco contato como um entrave na relação, conforme exemplificam algumas descrições: 
[...] os professores em geral têm pouco tempo para orientar, para tudo! Na verdade, eu acho que quem faz o trabalho é o alunō, meio que sozinho, o orientador apenas avaliza e faz sugestões, nada mais. Penso que, na verdade, o problema é do aluno. (Orientando 14)

Obviamente seria muito mais no sentido de disponibilidade de tempo, o problema é conseguirmos conciliar um momento de discussões mais longas. Acho que deveria haver um envolvimento maior dele agora. (Orientando 1)

Intransigência, dificuldade de acesso num primeiro momento, pois na minha turma de mestrado tinha muito disso! Começa por aí: tem o pouco acesso, começa a tomar decisões sozinho, torna-se um trabalho solitário e depois descobre-se que a sua visão não é a mesma do orientador. Aí, cria-se um primeiro ponto de conflito, quebrando-se um pouco daquela empatia e tudo começa a entrar em crise. (Orientando 9)

2) Outra categoria verificada foi a falta de comprometimento do orientando com as atividades de pesquisa da dissertação (2 respostas), como descrito abaixo:

[...] o orientador não resolve o problema de pesquisa dele e nem estabelece o problema de pesquisa. É o orientando que tem que resolver tudo! Então, esta falta de percepção do orientando do seu papel dificulta muito e desgasta a relação. $\mathrm{O}$ aluno quer transferir a responsabilidade para 0 orientador de uma coisa que é sua responsabilidade. (Orientando 9)

Existem outros fatores que estão dificultando o trabalho mais efetivo com ele, que é o volume de atividades aqui no mestrado: créditos, atividades dentro das disciplinas, seminários, trabalhos e provas. (Orientando 6)

3) Em se tratando de aspectos comportamentais, apenas dois orientandos relataram a falta de empatia entre o orientador e orientando (3 respostas):

Se você pega um professor que gosta do tema e não gosta do aluno, o resultado será pior ainda. [...] Primeiramente a empatia entre professor e aluno (Orientando 11)

[...] quebra-se um pouco daquela empatia, e tudo começa a entrar em crise. (Orientando 9)

4) Um orientando elencou a falta de sinceridade entre o orientador e o aluno, segundo o relato:

Uma coisa que tenho medo é o nosso relacionamento chegar a uma grande amizade [...] que permita o orientador não ser crítico com relação ao que eu estou fazendo, permita a ele não fazer críticas quanto ao meu trabalho, que não fale as verdades com relação ao meu trabalho. (Orientando 2)

Já na análise da resposta dos orientadores, diagnosticou-se apenas uma categoria, na qual estes sujeitos foram unânimes com relação a falta de tempo, disponibilidade e comprometimento dos alunos com as atividades da dissertação, sendo estes apontados como
Excluído: Acho que a questão do tempo atrapalhou um pouco, pois era difícil conseguirmos agendar encontros, em função dos nossos compromissos profissionais. (Mestre 1)ף

Excluído: [...] é a questão dele ter o tempo restrito, ele me dá toda atenção, mas tem que esperar até ele achar que te deve atender e isto tem me dificultado (Mestrando 5) ๆ 
os principais fatores comportamentais que dificultam a relação, conforme alguns depoimentos evidenciados a seguir:

\begin{abstract}
O principal fator seria a falta de observância do cronograma de pesquisa. Tenho casos de alunos que deixam tudo para última hora, causando um aborrecimento tremendo no orientador, e nos aspectos de relacionamento, isto é o que mais atrapalha, porque o professor não tem muito o que fazer, a responsabilidade é do aluno. (Orientador 6)

Uma grande preocupação com o comportamento depende, em grande parte, do departamento orientar o aluno que o curso não é uma grande especialização, que ele deveria ter uma maior dedicação, ter mais tempo. $\mathrm{O}$ aluno tem que encarar o mestrado como um curso de tempo integral mesmo! (Orientador 7)
\end{abstract}

Fazendo um comparativo entre as categorias dos orientadores e orientandos, verificou-se que os sujeitos são tendenciosos a imputar as responsabilidades da orientação aos seus opostos. Contudo, notou-se uma concordância de respostas na categoria falta de tempo e indisponibilidade dos sujeitos como um fator comportamental que dificulta a relação orientador-orientando, corroborando os estudos de Luna (1983), Santos Filho e Carvalho (1991), Martins (1997), Bianchetti e Machado (2002), sobre a falta de contato ou sua ineficácia e as suas influências negativas na orientação e no desempenho dos alunos.

A preocupação dos orientandos com o tempo e a disponibilidade dos orientadores poderia estar relacionada com as orientações da CAPES quanto ao aumento e concentração da orientação nos docentes de tempo integral (núcleo NRD6), pois, segundo as observações de Luna (1983), Warde (1993), Vasconcellos (1981) e Velho (2003), a manutenção concomitante das atividades de ensino e pesquisa, número elevado de alunos para orientar, cargos administrativos e outras atividades fora do ambiente universitário, poderiam ser os possíveis causadores de falta de tempo dos professores para prestarem uma assessoria melhor aos seus alunos orientandos.
Excluído: Do ponto de vista dos aspectos desfavoráveis, ainda alguns alunos insistem em deixar tudo para última hora. (Professor 3)ฯ 
Já a atribuição dos orientadores para a falta de tempo, dedicação e comprometimento dos orientandos poderia estar relacionada aos seguintes fatores:

- Falta da expectativa dos orientadores e orientandos quanto ao papel real da orientação e do papel de cada sujeito neste processo;

- Os sujeitos não saberem o que esperar de uma dissertação ou tese;

- Quantidade excessiva de créditos e atividades durante o curso de pós-graduação;

- Manutenção de atividades externas ao curso.

Os relatos a seguir ilustram estes fatores:

\begin{abstract}
Eu me senti solto no processo de orientação porque tinha determinados períodos que eu não sabia se estava no caminho certo, não sabia como fazer uma dissertação, e percebi que minha orientadora tinha dúvidas sobre isso também! (Orientando 13)

Na verdade meu orientador foi muito ausente [...] O que agregou na minha dissertação veio dos outros participantes da banca de qualificação mais que do orientador. (Orientando 11)

[...] seria um número menor de disciplinas durante os créditos [...] se você pega um orientador que não tem tanta disponibilidade e você tem um monte de disciplinas para fazer, dificilmente você vai conseguir ter um relacionamento estreito [...] acho que um fator terrível que dificulta o nosso desempenho é o volume de atividades nas disciplinas (Orientando 6)

Acredito que o aluno deve dedicar-se totalmente às atividades do mestrado e doutorado, não manter atividades externas, pois o programa não é uma grande especialização! (Orientador 7)
\end{abstract}

Entretanto, em se tratando de aspectos comportamentais, os orientadores não relataram preocupações em avaliar as características pessoais e afetivas dos alunos, confirmando-se a ênfase que os orientadores dão para os projetos e não para o sujeito orientando.

Com relação aos fatores técnicos e de conhecimento que facilitam a relação orientadororientando, para os orientandos, foram elencadas duas categorias, descritas a seguir:

1) Conhecimento técnico e específico na área aliado à fundamentação teórica para indicar caminhos (9 respostas). As descrições seguintes ilustram esta categoria: 
Do meu orientador, o que facilita é o domínio do conhecimento que ele tem sobre o que eu estou escrevendo. Penso que, se tem domínio do assunto, torna-se mais fácil discutir, transmitir as coisas. (Orientando 10)

[...] é conhecer o tema, conhecer do que o aluno está pesquisando, até porque pode indicar bibliografias, enfim criar caminhos. A função do orientador não é fazer o trabalho, mas orientar como atingir o resultado, o objetivo, para resolver o problema de pesquisa. Se o orientador não tem este conhecimento específico na área, dificulta um pouco. (Orientando 11)

2) Conhecimento em metodologia de pesquisa (8 respostas), experiência em orientação de trabalhos acadêmicos, saber o que é e o que se espera de uma dissertação ou tese (3 respostas), segundo as declarações abaixo:

O que auxilia bastante é o conhecimento da minha orientadora em metodologia da pesquisa, pois ela ministra esta disciplina. Então isso me ajuda a desenvolver um trabalho metodologicamente mais correto, mais adequado, e eu tinha uma enorme dificuldade neste sentido. Então, eu vejo isso como um fator facilitador. (Orientando 7)

Na escolha do meu orientador, fui mais para o lado da metodologia da pesquisa. Então, de conteúdo ele não é a pessoa que mais sabe de conteúdo. Mas por outro lado, pelo seu conhecimento e experiência em metodologia de pesquisa, ele consegue fazer uma crítica muito grande em relação à forma de estruturação do trabalho. Ele me ajuda a criar o caminho para atingir os objetivos propostos. Acredito que a questão metodológica é mais importante para mim. (Orientando 4)

Pelas respostas dos orientadores, foram identificadas duas categorias com relação aos fatores técnicos e de conhecimento que facilitam a relação:

1) Conhecimento específico e experiência do orientando na área escolhida para fazer a dissertação ou tese (6 respostas), exemplificados nos seguintes relatos:

Quando o aluno tem um tema e não tem conhecimento técnico nenhum, não teve nenhuma experiência prática na área, se não entende nada a respeito, fica uma leitura sem chão, se tem uma experiência técnica profissional, ele adquiriu conhecimento que irá produzir uma dissertação com mais profundidade, com mais conhecimento de causa. (Orientador 1)

A base do conhecimento específico do orientando é fundamental. Uma boa formação básica, aliada à experiência na área, do ponto de vista técnico, considero fundamental para o processo de orientação, pois o aluno não teria muita dificuldade [...] o que conta mais é o que o orientando traz com ela da sua graduação ou da sua experiência de vida. (Orientador 5)

2) Conhecimento do orientando em metodologia da pesquisa, aliado à experiência em trabalhos acadêmicos (6 respostas), elencados nas declarações a seguir:

Excluído: Acho que a experiência acadêmica e profissional de um aluno que ingressa no mestrado é o principal ponto que favorece. (Professor 6) ๆ

Se o tema que ele vem desenvolver estiver associado com alguma experiência acadêmica e profissional que ele teve, ou estiver relacionado com o que ele vem fazendo, é muito importante para o seu sucesso no mestrado. (Professor 7) 
[...] eu entendo que são os instrumentos de metodologia da pesquisa, é importante que o orientando conheça de metodologia da pesquisa e que ele tenha uma experiência no seu uso, que ele esteja aberto a discutir com o orientador, como é uma via de duas mãos, os dois aprendem neste processo [...] (Orientador 2)

O que vai facilitar é o estágio do projeto de pesquisa do orientando, a vivência em trabalhos acadêmicos [...] (Orientador 3)

Comparando-se as categorias evidenciadas para os orientadores e orientandos, com relação aos fatores técnicos e de conhecimento que facilitam a relação, verificou-se que a experiência prática aliada ao embasamento teórico e o conhecimento e a prática em metodologia da pesquisa foram relatados como fatores facilitadores pelos dois grupos - orientadores e orientandos. Também nesta questão, percebeu-se que os sujeitos são tendenciosos a imputar aos opostos suas responsabilidades, pois os orientandos responderam que o professor deveria saber metodologia da pesquisa, o que se espera de um trabalho acadêmico, enquanto que os orientadores relataram que os alunos deveriam ter alguma experiência em trabalhos acadêmicos e experiência técnica e profissional na área de interesse de pesquisa.

Por outro lado, não foram percebidos indícios de que os orientadores considerem a orientação como uma relação educativa, observada por Severino (2002), visto que dão ênfase à experiência profissional, ao conhecimento em metodologia delineado na apresentação do projeto de pesquisa, como indicadores de possibilidade de sucesso dos orientandos nos programas de pós-graduação.

Um ponto merecedor de atenção relatado pelos orientados foi "saber o que se espera de uma dissertação”. Martins (1997) relatou, em sua pesquisa, a supervalorização, dimensão distorcida e mistificação que o trabalho acadêmico ganha em função do não conhecimento dos seus requisitos. Percebe-se, com isso, o despreparo citado anteriormente por Martins (1994) e 
Haguette (1994), e possivelmente diferenças de visões do que se espera de uma dissertação ou tese entre os orientadores e orientandos.

Quanto aos fatores técnicos e de conhecimento que dificultam a relação orientadororientando, as respostas dos orientandos indicaram as seguintes categorias:

1) Falta de conhecimento específico na área, falta de fundamentação teórica para criticar e indicar caminhos (9 respostas), conforme descrito a seguir:

Que dificultam... bom, eu vejo que talvez quando se tratar de um assunto específico da área contábil, pois ela não tem experiência nesta área e a sua formação não é da área contábil. Já vi colegas falarem sobre isso, então considero como uma dificuldade, embora no meu caso, pelo meu tema, não tenha acontecido isso. (Orientando 7)

Seriam os que eu estou passando agora! Tecnicamente, sobre o tema, é a falta de leituras específicas. Com relação ao processo de orientação, uma coisa que me preocupa, é que o orientador é específico somente naquilo que ele vem estudando, isso é muito preocupante, pois as nossas idéias não estão batendo sobre algumas coisas que tenho pesquisado! (Orientando 1)

[...] e isso gera conflito de posições e entendimentos do assunto. É o caso do meu orientador que desenvolveu indicadores financeiros e eu insisti em indicadores não financeiros e a minha insistência venceu! (Orientando 10)

2) Falta de conhecimento em metodologia da pesquisa, aliada à falta de experiência em fazer trabalhos acadêmicos (4 respostas), segundo alguns relatos:

Acho que o fator metodologia da pesquisa é importante quando você explica um projeto de pesquisa, pois está tudo muito interligado. Não dá para separar isso: a carta de apresentação de um orientando para o orientador é o projeto de pesquisa, na minha visão. E isso, em muitos casos, não é feito, pois eu tive conhecimento de colegas. Você vai para bater um papo com o orientador e depois dali você quer que saia um projeto! Não sei se é bem isso que deveria ocorrer. (Orientando 9)

Já vi colegas que fizeram uma pesquisa bem profunda, mas que metodologicamente não conseguiram se dar bem, pois o trabalho estava mal elaborado. Eu acredito que a função do orientador é orientar, mostrar caminhos, e não fazer o trabalho para o aluno, mas ver a relação entre objetivos, justificativa, problema. (Orientando 12)

Pelas respostas dos orientadores, foram elencadas as seguintes categorias:

1) A falta da experiência técnica do aluno aliada à falta de fundamentação teórica do assunto (6 respostas), segundo algumas declarações:

Excluído: [ ] ] uma outra coisa, que a dissertação é a minha primeira experiência com trabalhos científicos, e fiquei muito perdida com a definição do tema, problema, metodologia, eu realmente tinha muita dificuldade nisto [...] (Mestrando 5) ๆ que estou estudando, acho que

basicamente este fator.

(Mestrando 4) I

Excluído: Às vezes o orientador até gosta do tema, mas por estar um pouco desatualizado com o tema e com o assunto [...] Então eu vejo que isso dificulta o processo: conhecimento acerca do

Excluído: Alguns assuntos o orientador não conhecia e por não conhecer, deixava passar em

branco e, às vezes, não confiava no que eu estava fazendo. 1

(Mestre 1 
Agora do ponto de vista do conhecimento, não havendo uma forte base conceitual, será o principal fator que atrapalharia o andamento dos trabalhos, e interferiria na relação com o orientador. (Orientador 5)

Tenho a impressão que, analisando, seria a contra-mão, por exemplo, o orientador defende uma linha de reflexão e o orientado defende outra linha, veja do ponto de vista técnico e de referencial fundamental bibliográfico, e isso é um problema que dificultaria, porque você teria um impasse. Se os dois não estivessem dispostos a suportar ou apoiar este novo conhecimento, que vem a partir de uma discussão, se não tiver motivação, indicação e interesse em descobrir uma coisa nova, eu tenho a impressão que vai acabar acontecendo um problema muito sério com respeito à relação orientador-orientando. (Orientador 2)

2) A segunda categoria refere-se à falta de conhecimento de metodologia da pesquisa e o uso desse conhecimento no trabalho pelo aluno (4 respostas), como exemplifica o relato abaixo:

\begin{abstract}
As principais dificuldades verificadas no processo de orientação são estágios, na verdade no começo de um trabalho você tem algumas dificuldades, como por exemplo ajustar uma questão de pesquisa, ajustar o foco do trabalho, então este é um problema que aparece num estágio inicial, depois, durante o desenvolvimento, você tem tanto o ritmo da geração do documento versus o ritmo da pesquisa bibliográfica e da pesquisa de campo, então isso é uma dificuldade, você dar cadência aos dois ritmos, para evitar aquelas famosas frases do tipo: "como é que está a sua tese, ah! Está excelente, mas tudo aqui na minha cabeça.” Essa cadência durante o desenvolvimento é uma dificuldade. (Orientador 2)
\end{abstract}

Percebe-se pelo relato dos orientadores que, em alguns casos, estas dificuldades em conhecimento específico na área do trabalho e a falta de conhecimento e prática em metodologia têm remetido os sujeitos a conflitos de opiniões e divergências de posições que acabam afetando o relacionamento orientador-orientando, corroborando um dos achados da pesquisa de Tunes (1981), a falta de conhecimento em metodologia, aliada a outras condições, era um fator que bloqueava o término das pesquisas dos alunos.

Os pontos comuns das respostas dos sujeitos, assim como os aspectos que facilitavam a relação, dão evidência de que a falta de conhecimento específico e técnico na área de pesquisa aliada à falta de embasamento teórico foram apontadas como principal entrave no relacionamento orientador-orientando. Juntamente com este fator, estaria relacionada a falta de conhecimento em metodologia da pesquisa, o que, provavelmente, acarretaria os conflitos 
de opiniões e posicionamentos, muitas vezes o orientador assumindo posições autocráticas (LUNA, 1983; MARTINS, 1997) e, como conseqüência da falta de habilidade do orientador em gerenciar conflitos, acabaria impondo esta sua posição para os alunos (MOSES, 1984; BROWN; ADKINS, 1998; PICCININ, 2003; MADSEN, 1993). O relato a seguir ilustra a posição de um orientador:

Não, a questão para mim nem é comportamental, nem de outros conhecimentos, porque você
define certas regras e normas e o aluno que se adapte, do ponto de vista comportamental esta é a
situação. Então, não tenho problemas desta ordem! (Orientador 4)

De uma forma geral, os fatores comportamentais relevantes destacados pelos sujeitos e elencados nas categorias foram o interesse e comprometimento do aluno com as tarefas do programa, a disponibilidade e acessibilidade dos professores e alunos, o conhecimento prévio da figura do aluno, respeito, confiança e empatia entre as partes. Os fatores técnicos e de conhecimento destacados nas categorias foram o conhecimento e a experiência na área específica de construção do trabalho monográfico aliados ao conhecimento em metodologia da pesquisa e experiência em trabalhos acadêmicos.

No agrupamento 3, foram analisadas as situações dos encontros de orientação, as dificuldades, sentimentos e sugestões dos sujeitos diante da relação orientador-orientando.

Com relação aos encontros e o ambiente da orientação, as respostas dos orientandos indicaram as seguintes categorias:

1) Encontros assistemáticos, informais, realizados somente quando a construção do trabalho apresentava alguma novidade ou ocorria alguma contingência (12 respostas). Alguns relatos ilustram esta categoria:

Os encontros foram assistemáticos. Nós marcávamos horários, como na verdade as duas agendas eram cheias, nós marcávamos horários para conversar umas duas ou três horas, e uma outra coisa 
que nós tínhamos, era que ele me dava uma tarefa e eu concluía, passava o texto para ele, e me retornava, com todas as marcas e observações bem detalhadas, eu fazia as alterações e nós voltávamos a conversar. (Orientando 13)

Os encontros não foram sistemáticos. Raramente eu agendei datas e encontros. Normalmente eu o procurava nos dias que eu vinha à escola e quando tinha alguma novidade no trabalho. Quando eu não tinha estes dois pontos, procurava até não passar na porta da sala dele para não ser cobrado (Orientando 14)

Não eram encontros sistemáticos, não eram planejados antecipadamente, pois o agendamento era muito difícil, pois tinha a questão do tempo. Era uma coisa totalmente sem planejamento, ligava quando tinha alguma particularidade, fazia muita coisa via correio eletrônico, então não tinha nada sistemático, quando dava a oportunidade da gente se encontrar, fazíamos as revisões e conversávamos sobre o trabalho. (Orientando 8)

2) Aliado a esta falta de periodicidade dos encontros, dois sujeitos relataram que os encontros foram insuficientes, sem o devido efeito no seu trabalho:

Os encontros foram assistemáticos e extremamente esporádicos. O clima foi amistoso, mas não com o retorno que eu julguei necessário. Eu sempre saía dos encontros sem sustentação daquilo que eu estava fazendo. Neste aspecto foi extremamente frustrante. Eu tive mais retorno da banca de qualificação do que do orientador. O que se agregou na minha dissertação veio dos outros participantes da banca, mais que do orientador. (Orientando 10)

Os encontros não foram sistemáticos. A gente se encontrava ocasionalmente, à medida que eu tinha dúvidas. Eu acho que a quantidade de encontros foi pequena, pois em dois anos de orientação, nos encontramos umas quatro vezes no máximo, eu achei pouquíssimo. Na verdade eu acho que deveria ter participado um pouco mais na definição dos capítulos, assim ele ter participado mais um pouquinho neste sentido. [...] Então não houve uma sistemática, alguns orientadores eu sei que fazem isso, são poucos pelo que eu sei, não houve esta sistemática e os encontros foram rápidos. Cada encontro durava vinte minutos e alguns deles foram numa lanchonete tomando café. Só teve um encontro um pouco mais demorado quando foi para qualificar: uma semana antes da qualificação e uma semana antes da defesa. Fora isso, todos os encontros foram aleatórios. (Orientando 11)

Verifica-se que esta categoria compatibiliza-se com as observações de Costa (2004), Loui (2003), Santos Filho e Carvalho (1991), nas quais os autores relatam que as dificuldades de se encontrar com o orientado e a ineficácia dos encontros faziam com que não surtissem efeitos no trabalho. Tal categoria também está relacionada com a categoria "falta de tempo, contato dos orientadores” (agrupamento 2), confirmando as posições de Haguette (1994). A autora relata que os orientadores são forçados a assumirem funções complementares que não lhes dizem respeito, não disponibilizando tempo para a atividade de orientação. Pelo relato dos sujeitos, observou-se também evidências de despreparo e descompromisso com a atividade de 
orientação, pois, ao deixarem os orientandos soltos, sem o devido retorno necessário, configurou-se uma atitude anti-educativa, conforme relatado na discussão teórica por Ferreira Sobrinho (2004).

3) Por outro lado, apenas dois sujeitos relataram que os encontros são sistemáticos e previamente agendados com os seus orientadores:

[...] começamos a marcar encontros, e sempre me atendeu nos horários marcados. Iniciou-se a orientação por e-mail, depois contato telefônico e depois todos encontros presenciais, muito diálogo, fui feliz neste aspecto. (Orientando 3)

Os encontros foram previamente agendados e eles se dão, são encontros marcados mensalmente, dentro destes intervalos tenho necessidade de procurá-la para tirar uma ou outra dúvida e a gente se encontra em intervalos menores que um mês e sempre tem ocorrido em termos de vinte dias, e todos os encontros são na PUC. (Orientando 7)

Contudo, verificou-se que mesmo com a sistematização dos encontros, foram mostrados indícios de que estes aconteceram em situações contingenciais, ou seja, demandados pelos orientandos, desconfigurando-se a sistematização relatada pelos orientadores.

4) Aliado às categorias anteriores, com relação ao clima dos encontros, três orientandos relataram que o orientador procurou manter uma posição de autocracia, de controle e domínio nos encontros, exemplificada nos seguintes relatos:

\begin{abstract}
Nos encontros eu ficava pouco à vontade por não conhecê-lo bem, tinha uma certa barreira. Então, ele fica se achando, sentindo-se superior aos outros professores, pois ele não aceita muito a opinião dos outros, porque acha que eles têm uma visão restrita e que a dele é a melhor. [...] Eu como orientanda, senti-me muito inibida por isso. (Orientando 5)

Os palpites com relação à costura do trabalho com os objetivos tratados no projeto, tem sido ora impositivos [...] então acabo acatando estas opiniões, sugestões autocráticas, por falta de conhecimento já fundamentado na pesquisa. Mas é uma autocracia quase que dialogada, ela explica as razões e os porquês das coisas e acaba me convencendo. (Orientando 7)
\end{abstract}

Ainda com relação aos encontros, as respostas dos orientadores permitiram a identificação das seguintes categorias:

1) Encontros assistemáticos e informais (3 respostas) (Orientador 4, 5 e 6); 
2) Aliado a esta categoria, e como conseqüência direta, os professores relataram que ficam na dependência do aluno para agendarem encontros, conforme os depoimentos abaixo (3 respostas):

Encontros... a freqüência depende do aluno... basicamente, ele tem que me trazer dois pontos: me manda o capítulo dois, no qual faço os comentários necessários, conserto este capítulo, as citações, às vezes eu mesmo escrevo certas páginas para o aluno, para dar um exemplo para ele como eu quero que a coisa seja feita. Logo após, ele pega este capítulo, leva para a casa e refaz, enquanto ele não entender esta parte do capítulo 2 - revisão bibliográfica - ele não vai para a frente. A partir daí, começamos a tratar dos assuntos técnicos e específicos do trabalho. (Orientador 4)

No meu caso, a freqüência dos encontros varia muito de um orientando para outro. Os encontros são assistemáticos, geralmente vamos agendando de acordo com o andamento dos trabalhos dos orientandos, não há uma periodicidade programada. (Orientador 5)

O que acredito que melhoraria o nosso programa é se os encontros com os orientandos fossem todos agendados, seguindo um cronograma, mas o ritmo dos encontros é dado pelos próprios alunos, em decorrência do andamento dos seus trabalhos. (Orientador 6)

3) Por outro lado, identificou-se uma categoria na qual os professores relataram que os encontros são sistemáticos e previamente agendados (4 respostas), segundo algumas descrições:

Os encontros são todos agendados e são todos sistemáticos, a gente sempre sabe o ritmo e a intensidade, de uma forma muito transparente, sempre que há a necessidade, deixo aberta a possibilidade de nós nos encontrarmos. (Orientador 2)

A partir do momento que identifiquei que o aluno será meu orientando, eu procuro criar canais de comunicação. Da minha parte, tudo aquilo que considero importante comentar eu comento, eu instigo e incentivo manter contato comigo. A partir daí, estabelece-se uma dinâmica sistemática, no mínimo, mensal. No nosso modelo de gestão, os alunos não ficam órfãos. (Orientador 3)

Eu prefiro reuniões sistemáticas, antecipadamente planejadas. Os encontros são na universidade, ou se necessário na empresa, na associação, porque acredito que as idéias que o aluno irá colocar na dissertação estejam calcadas da opinião de outros profissionais. (Orientador 7)

As categorias também permitiram identificar perfis de professores e como estes têm considerado o processo de orientação. Pelos relatos, foi identificado que três dos sete entrevistados assumiram posições autocráticas, de domínio dos encontros, submetendo os alunos aos seus interesses e idéias, conforme alguns exemplos de citações a seguir:

Com todas estas pressões da CAPES em formar mestres num período mais curto, o gerenciamento e agendamento das reuniões de orientação devem ser mais rígidas, o que não tem acontecido aqui na escola. (Orientador 6)

Excluído: As minhas posições endem muito do perfil do aluno: tem aluno que você precisa ser autocrático, pois

democraticamente a coisa não funciona! (Professor 7) ๆ 
Eu sei que existe um pensamento e uma percepção de que o orientador é co-responsável pela qualidade do trabalho, mas acredito que esta responsabilidade do professor é pequena. A responsabilidade maior é do aluno, e eu deixo isso claro para todos os meus orientandos. (Orientador 5)

Por outro lado, quatro dos sete orientadores pesquisados enfatizaram que procuram trabalhar de uma forma democrática, como mostram os seguintes relatos:

O clima dos encontros geralmente é agradável, assumo uma posição democrática. Então, concluindo, eu coloco as coisas a título de sugestão, eu mostro o meu ponto de vista dizendo: eu acho que ficaria melhor assim, mas a decisão de aceitar ou não, é sua! (Orientador 5)

A relação é de parceria: eu leio o trabalho, passo para ele ler, e fazemos isso no começo, algumas vezes, até que consolide o formato, até que o aluno perceba. (Orientador 4)

Comparando-se as categorias dos orientadores e orientandos, percebe-se que foram compatíveis ao relatarem que os encontros de orientação ocorrem de forma assistemática e informal, com os encontros para orientação figurando sempre pela dependência do orientando. Pelos relatos, entendeu-se que, na verdade, é o orientando que demanda a orientação, independentemente do professor trabalhar sistematicamente ou não. Este aspecto corrobora a pesquisa de Martins (1997, p. 62), na qual o autor cita que “[...] a periodicidade dos encontros varia da vontade e iniciativa do orientando”; de Luna (1983, p. 179), “[...] não tenho procedimento definido, fico na dependência do aluno. O caráter idiossincrático da relação é determinado pelos alunos.” Embora não relatado pelos orientadores, dois orientandos comentaram que, além da não periodicidade, a quantidade dos encontros foi considerada insuficiente e sem efeitos no trabalho.

Também merecedora de atenção é a posição autocrática de alguns professores nos encontros, perante a orientação. Warde (1997), Severino (2002) e Zilbermann (2002) observam que o professor, sendo um educador, deveria considerar a orientação como um processo de ensinoaprendizagem, pois posições autocráticas poderiam trazer problemas de relacionamento que afetariam a conclusão dos trabalhos. Possivelmente as posições autocráticas dos professores 
poderiam também estar relacionadas pelas pressões externas exercidas pela CAPES aos programas com relação ao cumprimento dos prazos e pela ausência da responsabilização do professor pela qualidade e término do trabalho. Foi percebido no discurso dos orientadores o entendimento de que a responsabilidade da dissertação ou tese paira somente sobre aluno. Entende-se a dissertação ou tese como uma construção conjunta que reflete sobremaneira os estilos do orientador e do orientando, sendo resultado de um esforço conjunto e coordenado de ambas as partes.

A informalidade dos encontros e a autocracia, conjugada com outros fatores, poderiam provocar nestes sujeitos sentimentos de angústia, solidão e isolamento (MARTINS, 1997; LUNA, 1983; SANTOS FILHO; CARVALHO, 1991; CARVALHO, 1994). A flexibilidade do roteiro de entrevistas permitiu verificar se os orientandos apresentavam estes aspectos, evidenciados em alguns relatos, descritos a seguir:

\begin{abstract}
Acho que é um aspecto desconfortável para ele, pois quer que eu traga e desenvolva as idéias, não que fique moldado a ele. Acho que a angústia e solidão todos sentem, e esta angústia é sentida de uma forma mais intensa no prazo. (Orientando 1)

Então, todas as vezes que eu ia conversar com meu orientador, ele nunca estava com a última versão que havia lhe entregado, isso me deixou inseguro no término do trabalho, pois eu não tinha um retorno daquilo que eu estava fazendo. (Orientando 10)

No relacionamento me senti mais solto, acho que andei pelas próprias pernas, não era o que eu imaginava, mas de qualquer forma, se eu tivesse um apoio maior, mais constante, talvez teria feito a dissertação num prazo mais curto. (Orientando 8)

[...] apesar de alguns momentos me sentir solto, às vezes que precisei ele me atendeu. Achei até que precisaria de mais encontros com ele (orientador). (Orientando 3)
\end{abstract}

Os relatos mostraram que os orientandos se sentiram muito inseguros com relação à orientação, apresentando sentimentos de solidão, causados principalmente pela distância e pela falta de contato periódico com os seus orientadores, conforme observado pelo relato dos orientandos. Desta forma, acredita-se que estes sentimentos dos orientandos poderiam ter sido provocados pelos seguintes fatores:
Excluído: Apesar de eu me sentir desamparado e mais livre para fazer a dissertação, eu sempre tive a resposta adequada e acredito que a realidade funciona assim, e eu pretendo continuar assim. Me senti desamparado e solto. (Doutorando 1) ๆ 
- Falta de contato periódico entre orientador e orientando;

- Falta de apoio do orientador, por meio de leituras do material, indicação de medidas corretivas, ausência de um retorno satisfatório acerca do trabalho;

- Pressão exercida pelos orientadores para conclusão dos trabalhos, em função do achatamento dos prazos de conclusão;

- A falta de consenso do que é a atividade de orientação, orientadores assumindo diversas posições, alguns entendendo que o aluno devesse pesquisar somente temas de seu interesse sob um rígido esquema de orientação, outros deixando os alunos totalmente soltos, perdidos, sem direção;

- Ausência de planejamento das atividades de orientação;

- Desentendimento do que esperar de uma dissertação ou tese, criando distorções das mais variadas formas;

- Desconhecimento das funções, direitos e deveres da figura do orientador e do orientando, onde deveria existir uma relação de ensino-aprendizagem.

Indagados sobre possíveis sugestões para minimização e superação dos obstáculos e dificuldades no processo de orientação, pelo relato dos orientandos, foram estabelecidas as categorias a seguir:

1) Os orientandos sugeriram uma maior proximidade entre os sujeitos, de forma a minimizar as diferenças de opiniões, conflitos e reduzir os sentimentos de angústia e solidão, conforme as seguintes descrições:

Muitos problemas que podem surgir na caminhada e na relação orientador-orientando devem-se, talvez, à falta de conhecimento, ou seja, um estar mais próximo para conhecer o outro, isso me parece fundamental. Se eu pudesse aconselhar, diria o seguinte: precisa estar mais próximo do orientador, manter um contato permanente. (Orientando 15)

Ter um acompanhamento mais direto e pessoal do orientador, principalmente na reta final. (Orientando 1) 
Talvez da minha parte tenha faltado esta insistência no contato, porque eu estava pesquisando e desenvolvendo. Num certo aspecto foi até interessante caminhar sozinho, mas acho que a presença do orientador deve ser mais constante. (Orientando 10)

2) A possibilidade de se trabalhar os encontros de forma democrática, respeitando as opiniões e limitações dos orientandos, segundo as descrições:

Para os problemas e dificuldades é você conseguir discutir de igual para igual, porque, na verdade, muitas vezes eles não sugerem, eles impõem mudanças na sua linha de raciocínio, naquilo que você realmente se propõe a fazer, dá este corte de maneira impositiva. (Orientando 3)

[...] é uma relação até certo ponto desgastante, pois as pessoas têm tempos diferentes, então ambas as partes devem respeitar o tempo, cronogramas, buscar organização [...] De certa forma, do orientador, que ele respeite as limitações, não faça com que a qualidade do trabalho seja menor por causa das limitações, mas crie caminhos mais fáceis para que este orientando chegue. (Orientando 9)

Para os orientadores, foram elencadas as seguintes categorias acerca das sugestões para superação de obstáculos e dificuldades:

1) Manutenção de contato periódico com os orientadores ligada a uma maior disponibilidade de tempo de ambos para a orientação, segundo alguns relatos:

Acho que a dissertação de mestrado é dedicação, horas de trabalho, tempo em cima da cadeira, acho mais importante é a disposição de tempo de cada um. Se você quiser uma regra, o ideal é o sujeito não trabalhar, daí ele terá uma disponibilidade de tempo maior. (Orientador 4)

Acho que um fator facilitador é a presença física do orientando e do orientador, para que eles estejam sempre se encontrando, se reunindo, e vejo uma relação direta entre a qualidade do trabalho e a quantidade de encontros. Um fator que facilitaria é a constância que os sujeitos deveriam estar aqui na escola o maior tempo possível. (Orientador 5)

2) O aluno já entrar no programa com a idéia e o tema de pesquisa definidos, na área de interesse do professor, conforme algumas declarações a seguir:

Um ponto fundamental é termos nossos alunos em áreas de pesquisa e projetos. Admitindo-se que os alunos que não têm temas definidos deverão se enquadrar em temas de interesse dos professores com projetos já definidos. (Orientador 3)

Eu tenho comigo, dada a relevância do trabalho acadêmico para um programa de mestrado e doutorado, o camarada antes mesmo de vir para o programa, pudesse ter uma idéia ou noção do tipo de pesquisa que está sendo feita aqui, quais são os orientadores, isto seria um passo à frente. (Orientador 2)
Excluído: Acho que é ter um contato maior com o orientador. Isso me facilitou não só do ponto de vista comportamental de relacionamento, mas do ponto de vista das idéias, eu já sei para qual linha que ela vai, então é mais fácil ter uma congruência de pensamentos e ela me conhece. (Mestre 5) ๆ
Excluído: Acho que um dos grandes obstáculos é quando os temas não são de interesse do orientador. Daí fica uma orientação desorientada, e o processo cheio de falhas. Para quebrar isso, é de fato fazer com que o orientando pesquise de fato o que o orientador está interessado em pesquisar, porque daí haverá uma compatibilidade. (Professor 1) 
Observou-se que a tendência dos entrevistados, de modo geral, foi descrever suas experiências ou fatores que tenham vivenciado e que consideraram relevantes para melhorar o processo de relacionamento entre os sujeitos. Os orientandos foram tendenciosos ao sugerir uma maior proximidade com os orientadores, justamente por buscarem uma segurança na orientação, o que poderia ser função do seu incipiente conhecimento em metodologia de pesquisa, principalmente no mestrado, por ser a primeira pesquisa de fôlego. Os orientandos também sugeriram encontros mais democráticos, nos quais pudessem discutir as suas idéias em nível de igualdade com os orientadores, confirmando as evidências de reuniões autocráticas entre orientadores e orientandos, nas quais os professores não aceitavam com muita facilidade as idéias dos orientandos, evidenciadas em categorias descritas anteriormente.

Além disso, os orientandos sugeriram que se deveria priorizar o tempo na definição do tema de pesquisa, principalmente pelos alunos ingressantes no programa. Este fator confirma uma das sugestões dos orientadores, que o aluno já adentrasse no programa com um tema e um projeto de pesquisa definidos e que os levasse adiante, minimizando-se, assim, o desgaste natural da escolha do tema, além da minimização dos sentimentos de isolamento, conflitos de posições e opiniões e alavancando o andamento das pesquisas.

Os orientadores indicaram como sugestão a manutenção de contato periódico com os orientandos. Porém, percebeu-se que os orientandos é que vão aos professores orientadores, recaindo nos orientandos, de forma indireta, a responsabilidade pela condução e sucesso do trabalho. Por outro lado, estes mesmos orientadores sugeriram uma maior disponibilidade de tempo dos sujeitos - orientadores e orientandos - para as tarefas da orientação, denotando que 
estes não têm disponibilizado tempo suficiente para seus alunos, assumindo também uma carga de responsabilidade ora imputada aos seus alunos orientandos.

No agrupamento 4, foram observados os aspectos relacionados à associação entre a qualidade de uma tese ou dissertação e a orientação recebida. Na visão dos orientandos, foram elencadas três categorias:

1) Os orientandos acreditam que a qualidade do trabalho depende da orientação recebida (12 respostas), sobretudo nos aspectos metodológicos, quando os sujeitos mantêm encontros periódicos, quando há acessibilidade, e quando os orientadores fazem leituras dos textos produzidos pelos alunos, indicando caminhos e sugestões, segundo os relatos:

\begin{abstract}
Eu acredito que sim, porque se você está seguro com a orientação recebida, você desenvolve um trabalho melhor, porque você sempre fica se perguntando: será que o meu trabalho está bom? Será que o que estou fazendo está certo mesmo? [...] afinal de contas, se você tem segurança na orientação, acaba desenvolvendo um trabalho melhor, o papel do seu orientador é te mostrar o caminho pois ele tem experiência naquilo [...] (Orientando 5)

Eu acredito que sim, pois se você fizer um trabalho distante do orientador, sozinho, sem que ele tenha dado um apoio muito forte para você, você pode estar correndo riscos de cometer erros primários, erros que facilmente seriam evitados se ele tivesse dado um auxílio maior. Eu acho que esta é a função principal do orientador: te mostrar atalhos, te livrar de armadilhas, te mostrar caminhos mais fáceis. (Orientando 6)

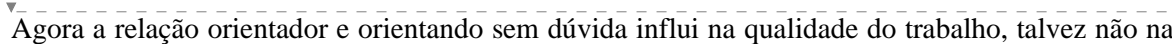
mesma proporção do que eu te falei, mas sem dúvida que influi. Eu vejo isso na minha dissertação de mestrado, não querendo contar vantagem, mas foi muito elogiado pela banca e a professora orientadora teve uma participação essencial no negócio, naqueles momentos que ela sentou comigo para rever o trabalho, para sugerir melhorias, aquilo melhorou demais. (Orientando 12)
\end{abstract}

2) Por outro lado, dois orientandos relataram que a qualidade da dissertação, além de guardar relação com a orientação recebida, dependeria mais das ações do orientando, conforme as seguintes descrições:

Particularmente a qualidade depende muito mais do orientando, da pessoa que está fazendo, do que o orientador. Mas acho que o orientador contribui muito desde que sejam identificadas estas necessidades. Na minha dissertação a qualidade está sendo aumentada com a figura do orientador. (Orientando 4)
Excluído: Sim, acho que sim [...] se você tem um professor que te orienta de tempos em tempos, conhece do tema, é bem sistemático no modo de trabalhar, com certeza você terá uma boa dissertação e um bom resultado porque qualquer avaliação que será feita do trabalho é um processo, um acompanhamento, na medida que você vai fazendo, o orientador vai acompanhando [...] de forma que no final terá um ganho em qualidade muito grande! (Mestre 4)ף 
Não necessariamente, depende mais do orientando. [...] A partir do momento que você lê, pesquisa sobre determinado assunto você irá superar o seu orientador porque você estará trazendo coisas novas sobre o tema, pois quem estará fazendo a pesquisa é você! (Orientando 14)

Com relação aos orientadores, foram unânimes ao relatarem que a qualidade do trabalho tem relação com a orientação recebida, destacando-se algumas características dos sujeitos, tais como o diálogo entre as partes, leituras e embasamento teórico, indicação de caminhos, engajamento dos alunos no processo e empatia entre os sujeitos. Os relatos abaixo ilustram esta categoria:

Eu diria que depende, porque se você partir do pressuposto que um curso de mestrado precisa ter uma produção científica que necessita estar ligada a áreas de conhecimento e para isso precisa de linhas de pesquisa e projetos, quanto mais o professor estiver engajado nisto, mais sucesso você tem numa dissertação de mestrado de apresentar qualidade (Orientador 3)

Depende! A qualidade do trabalho, seja uma dissertação ou tese, depende muito da empatia que surge entre orientador e orientando, especialmente quando o tema está na linha do orientador, porque o orientador tem interesse em aprofundar muito mais na temática analisada, sendo muito útil para o orientador fazê-lo através de um aluno, orientando, que está também interessado neste tema. Essa qualidade é uma conseqüência direta da orientação recebida. (Orientador 7)

Eu acredito que é essa a figura do orientador: uma pessoa um pouco mais experiente em fazer o trabalho, que já fez trabalhos, já orientou alguns outros. Então na realidade seria uma experiência maior, esta questão do método poderia ser evitada. Se ele se furta disto, o pobre coitado do aluno vai cair nas mesmas armadilhas e acaba sendo prejudicado, aprende o que é, mas em função dos prazos que são constantes e outros recursos, o produto final acaba tendo interferência na qualidade. Acho que não é dispensável a relação pode influenciar na qualidade para cima e para baixo. (Orientador 2)

Aliado à categoria anterior, dois orientadores, assim como dois orientandos, relataram que a qualidade de uma dissertação ou tese dependeria mais do aluno, como segue:

Ah! Eu entendo que depende sim. Acredito que depende da orientação recebida. Mas eu acredito que depende muito mais do próprio orientando, da postura dele, da seriedade com que ele encara o trabalho de pesquisa, do gosto dele pela pesquisa. Depende em menor grau da orientação.

(Orientador 5)

Eu não acredito que seja tão dependente, pois temos aí uma intermediação muito grande, é um processo que depende de um trabalho do orientador e do orientando em conjunto, em sintonia, agora, evidentemente que a orientação efetivamente séria e segura ajuda bastante na qualidade do trabalho. (Orientador 6)

Excluído: Qualidade: bom, sim, na grande maioria das vezes. Mas há aqueles alunos que são brilhantes, e criam uma

independência. (Professor 4) 
As categorias diagnosticadas nos relatos dos orientandos e orientadores dão evidências de que a relação orientador-orientando influenciou na qualidade do trabalho. Diagnosticou-se que cinco dos quinze orientandos entrevistados e a totalidade dos orientadores indicaram que 0 orientador desempenha um papel diretivo no processo de construção e na qualidade do trabalho, corroborando as observações de Velho (2003), Machado (2002) e Marques (2002). Por outro lado, acenaram que a acessibilidade, empatia, respeito e comprometimento dos orientadores e orientandos no processo são condições que contribuem para facilitar e dar mais tranqüilidade aos orientandos perante a orientação, contribuindo sobremaneira no desenvolvimento e na qualidade dos trabalhos.

Diagnosticou-se também que dois orientandos e dois orientadores foram concordantes no sentido de não deixar o peso da orientação somente para o orientador, visto que a relação é uma via de duas mãos (SEVERINO, 2002; BIANCHETTI; MACHADO, 2002). Estes sujeitos destacaram que a qualidade do trabalho relaciona-se com a parceria estabelecida entre orientador e orientando. Esta parceria, juntamente com as demais condições citadas, poderia ser condicionante da qualidade dos trabalhos.

Este capítulo apresentou a descrição, análise e discussão dos resultados das entrevistas com orientadores e orientandos pertencentes à amostra pesquisada. A análise foi efetuada com a criação de categorias de análise e agrupamentos de categorias (áreas temáticas) em concomitância com os objetivos assumidos e também como forma de organizar o capítulo de forma lógica. Os resultados validaram aspectos relatados no referencial teórico, bem como indicaram posições e atitudes dos sujeitos nos programas de pós-graduação em Contabilidade da capital paulista. 
O capítulo a seguir apresenta as conclusões preliminares e tece algumas sugestões para continuidade dos estudos nesta temática, indicando novas e complementares investigações que poderão ser feitas a partir deste trabalho. 


\section{CONCLUSÕES PRELIMINARES E ALGUMAS SUGESTÕES}

O objetivo do estudo foi diagnosticar, caracterizar e compreender os principais aspectos da relação orientador-orientando e as suas influências no processo de produção de teses e dissertações nos programas de pós-graduação em Contabilidade na cidade de São Paulo.

As conclusões deste estudo reafirmaram e validaram opiniões, relatos e posicionamentos levantados na revisão teórica, explicitados nas entrevistas, permitindo, sobretudo, a identificação de interessantes categorias sobre a relação orientador-orientando nos programas de pós-graduação stricto sensu em Contabilidade na cidade de São Paulo.

Como forma de responder o problema de pesquisa, descreve-se, a seguir, os principais aspectos da relação orientador-orientando que influenciam o processo de produção de teses e dissertações nos programas de pós-graduação stricto sensu em Contabilidade da capital paulista:

Na escolha dos orientadores, os orientandos consideraram a congruência de interesses de pesquisa em determinado assunto ou determinada linha de pesquisa. Esta escolha estaria relacionada com alguma experiência anterior do orientando com o orientador, em aulas, pesquisas, projetos, denotando indícios de que este contato anterior gerou nos sujeitos uma certa afinidade pessoal e empatia.

Quanto às condições e requisitos para aceitação de alunos para orientação, os orientadores e os orientandos foram tendenciosos ao verificar a compatibilidade de interesses nas linhas de pesquisa e no direcionamento dos orientandos nas ambições de pesquisas dos orientadores, 
além da dedicação, disciplina na confecção dos trabalhos, cumprimento de prazos. Contudo, orientadores também foram tendenciosos ao direcionar as pesquisas, fazendo orientandos pesquisarem temas de seus interesses ou que julgam relevantes para a área de conhecimento. Foram descobertas evidências de que os orientadores, nas suas escolhas, valorizaram mais as características técnicas dos orientandos, enquanto que os orientandos valorizaram mais as características afetivas e pessoais dos orientadores.

Os fatores comportamentais elencados como facilitadores do relacionamento foram o comprometimento, acessibilidade, respeito e facilidade de comunicação entre as partes. Os fatores comportamentais que dificultariam a relação foram a falta de contato periódico entre os sujeitos, inacessibilidade, falta de tempo e comprometimento dos sujeitos com as atividades de orientação. Também foi evidenciado que a falta de empatia é um entrave no relacionamento dos sujeitos.

Quanto aos fatores técnicos e de conhecimento que facilitam a relação, foram enfatizados o conhecimento técnico específico na área de pesquisa, conhecimento e experiência em metodologia de pesquisa, principalmente saber o que se espera de uma dissertação ou tese. Os sujeitos denotaram que a falta de conhecimento específico na área, aliada à ausência de conhecimentos de metodologia, foram as principais evidências de fatores técnicos e de conhecimento que dificultariam a relação.

Com referência aos encontros de orientação, $20 \%$ dos orientandos relataram como sistemáticos e $80 \%$ assistemáticos, $20 \%$ em clima de autocracia, e com relatos de que eles não produziram efeitos significativos na qualidade do trabalho (15\%). Todavia, percebeu-se que, mesmo quando há sistematização, os encontros são contingenciais. Através da análise do 
relato dos sujeitos, percebeu-se que a falta de sistematização e o ambiente de autocracia provocaram nos orientandos sentimentos de insegurança, angústia e solidão, sendo que tais sentimentos também foram decorrentes da falta de contato, da conseqüente falta de apoio, direcionamento e retorno dos orientadores, das pressões com relação à diminuição dos prazos de conclusão dos cursos e da ausência de entendimentos do que se esperar de uma dissertação ou tese e do papel de orientadores e orientados no processo. Por outro lado, 57\% dos professores orientadores pesquisados dividiram-se em encontros sistemáticos e $43 \%$ em assistemáticos; assumiram posições autocráticas e democráticas, dependendo do seu perfil e do perfil do aluno orientando. Contudo, uma característica marcante percebida pelo depoimento dos sujeitos foi que os encontros, na sua grande maioria, surgiram da necessidade emergencial do orientando, e que, conjugado com os fatores falta de tempo e inacessibilidade dos orientadores, poderiam estar provocando aspectos negativos no relacionamento orientador-orientando.

Como sugestões para minimização das barreiras e dificuldades no relacionamento, os sujeitos indicaram uma maior aproximação entre orientador e orientando, a possibilidade de trabalhar encontros de forma democrática criando no orientando uma auto-responsabilidade e abertura para debates, minimização no tempo de definição do tema de pesquisa, manutenção de contatos periódicos e a possibilidade de o aluno ingressar no programa com um tema já definido e continuar a sua pesquisa com ele.

A maioria dos sujeitos apontou indícios de associação entre indicadores de qualidade e aspectos da relação orientador-orientando, principalmente quando se observam os seguintes itens: 
- Acessibilidade, contato e diálogo entre os sujeitos, e quando suas relações afetivas transcendem os aspectos técnicos, gerando confiança, respeito e autonomia intelectual nos orientandos;

- Quando os orientadores assumem efetivamente seu papel, fazendo leituras críticas, indicando caminhos, numa relação dialética e diretiva, minimizando sentimentos de isolamento intelectual dos orientandos.

Os resultados conseguidos, aliados ao interesse manifestado pelos entrevistados, sugerem aprofundamentos de estudos sobre esta temática que utilizem amostragens maiores, que englobem a totalidade dos programas de pós-graduação em Contabilidade e que sejam extrapolados para outras áreas.

Como sugestões para um melhor relacionamento orientador-orientando, com base nos achados das entrevistas e corroborando os estudos anteriormente citados, indicam-se alguns caminhos:

a) Criação de espaços acadêmicos de discussão e reflexão do que se espera de uma dissertação ou tese e sobre a qualidade da produção científica dos programas, permitindo o estabelecimento de idéias e sugestões para um melhor relacionamento orientador-orientando;

b) Realização de seminários entre orientadores e orientandos, com um espaço aberto para que os futuros orientandos conheçam melhor os orientadores, para a troca de experiências, buscando valorizar a carga horária dedicada à orientação nos programas de pós-graduação;

c) Utilização de modelos de orientação coletiva, criando-se a figura do co-orientador, numeração visto que tal modelo já é consolidado em outras universidades e programas 
brasileiros, de forma a minimizar as contingências e contribuir para o enriquecimento técnico e metodológico dos trabalhos;

d) Utilização de noções de relacionamento interpessoal, aliada a noções de aconselhamento e orientação psicológica, tais como o reconhecimento de individualidades, tipos psicológicos e outros, no sentido de que, a partir destes métodos, se obteriam melhores condições para adequar procedimentos e condutas em função das características pessoais, intelectuais e comportamentais de cada pessoa;

e) Sugestão de encontros dos orientandos do mesmo orientador com um espaço aberto para discussão de aspectos técnicos, de conteúdo e comportamentais destes sujeitos, objetivando melhorar o relacionamento entre orientadores e orientandos, reduzindo as distâncias e diferenças existentes entre eles;

f) Outra sugestão seria os orientadores acompanharem os orientandos durante as disciplinas no programa, para que não ocorra o curso de disciplinas sem sinergia com o projeto de pesquisa do orientando, tendo assim uma otimização de tempo;

g) Verificou-se também que não há consenso do que se esperar de uma dissertação e tese. Uma sugestão para minimizar este problema seria os orientadores incentivarem os orientandos a criarem o hábito de participarem de sessões de defesas de teses e dissertações, nas suas unidades e fora delas, criando-se esta cultura, como forma do pós-graduando conceber as suas próprias concepções acerca dos trabalhos, posturas diante de uma banca, além de conhecer atitudes e perfis de orientadores e professores.

Espera-se que o presente estudo possa trazer indagações a outros, instigando a realização de pesquisas que aprofundem e enriqueçam a compreensão deste estimulante tema. Desta 
maneira, tecem-se as seguintes sugestões temáticas para pesquisas futuras, que possam dar continuidade a este estudo:

a) Indica-se entrevistar orientando que rompeu com orientador e passou a ser orientado por outro, conseguindo ter sucesso na conclusão do seu projeto, e entrevistar orientadores que passaram pela experiência de terem orientandos desistentes, como forma de entender os motivos que levaram os orientandos a tomarem estas atitudes, bem como a posição dos sujeitos diante destas circunstâncias;

b) Investigar a relação entre a qualidade da dissertação ou tese com a orientação recebida por orientadores que sempre repetem a bibliografia nas orientações e também com orientadores que mantém corporativismo nas bancas de qualificação e defesa, que sempre escolhem as mesmas figuras fixas para as bancas de seus orientandos;

c) Pesquisar orientandos que tiveram problemas de relacionamento com o orientador, tendo estes problemas sido superados ou contornados após uma conversa franca, e que tiveram sucesso na conclusão dos seus projetos. Salienta-se que este não foi o objetivo deste estudo, indicando-se esta temática para pesquisas futuras;

d) Entrevistar orientadores e orientandos buscando levantar qual o nível de satisfação que estes sujeitos estavam sentindo ou sentem no processo de orientação;

e) Ampliar o estudo para áreas correlatas, investigando orientadores das áreas de Recursos Humanos, Marketing, Psicologia, de forma a comparar se estes apresentam um perfil diferente dos orientadores das outras áreas. 


\section{REFERÊNCIAS}

ALMEIDA, Edson Pinto de. Escolha de pós pesa mais no alto escalão. Valor Econômico. Caderno Educação Executiva, p.F4, São Paulo, 22 de outubro de 2003.

ALVES, Alda Judith. Revisões bibliográficas em teses e dissertações: meus tipos inesquecíveis. Cadernos de Pesquisa. São Paulo. Fundação Carlos Chagas/Cortez, n. 81, p.53-61, maio de 1992.

O planejamento de pesquisas qualitativas em educação. Cadernos de Pesquisa. FCC. São Paulo. n. 77, p.53-61, maio 1991.

ANQUETIL, Nicolas. Sobre a relação orientador-orientando. Disponível em <http://geocities.yahoo.com.br/kellyne_se/orientar.htm>. Acesso em: 10/09/2003.

ARAGÒN, Virgílio Alvarez. Situação e desafios da pós-graduação na América Latina.

Cadernos de Pesquisa. São Paulo. Fundação Carlos Chagas. n. 105, novembro, 1998 v

BEIGUELMAN, B. Reflexões sobre a pós-graduação brasileira. In: PALATNICK et al. (Orgs.). A pós-graduação no Brasil. Rio de Janeiro: UFRJ, 1998.

BERNDT, Alexander. A questão da orientação na pós-graduação em Administração. Disponível em < http://www.forvm.org.br/educarnav.html>. Acesso em: 18/08/2003.

BIANCHETTI, Lucídio (Org.). Trama e texto: leitura crítica, escrita criativa. V.1. São Paulo: Plexus, 1997.

BIANCHETTI, Lucídio; MACHADO, Ana Maria Neto (Orgs.). A bússola do escrever: desafios e estratégias na orientação de teses e dissertações. Florianópolis/São Paulo: Editora da UFSC/Cortez, 2002.

BRASIL. Ministério da Educação. Resolução $n^{0}$ 05, de 10/03/83. Fixa normas de funcionamento dos cursos de pós-graduação stricto sensu. Disponível em $<$ http://www.capes.gov.br/documentos/legislacao/resolucao_CFE_05_1983.doc>. Acesso em $17 / 04 / 2004$

BROWM, G.; ADKINS, M. Effective teaching in the higher education. London: Routledge, 1998. 
CALDAS, I. Propostas para a pós-graduação. In: PALATNICK et al. (Orgs.). A pósgraduação no Brasil. Rio de Janeiro: UFRJ, 1998.

CAPES - Coordenação de Aperfeiçoamento de Pessoal de Nível Superior. Disponível em <http:www.capes.gov.br>. Acesso em 2003.

CARVALHO, Cristina Vilela de. Em busca de uma obra: considerações psicanalíticas sobre o processo de elaboração de uma dissertação de mestrado. 1994, 380 p. Dissertação (Mestrado em Psicologia) - Instituto de Psicologia da Universidade de São Paulo, 1994.

CASTRO, Cláudio de Moura. Dissertando sobre dissertações. Seminário sobre a produção científica nos programas de pós-graduação em Educação. Brasília: Departamento de Documentação e Divulgação. MEC, 1979, p. 29-64.

. Memórias de um orientador de tese: um autor relê sua obra depois de um quarto de século. In: BIANCHETTI, Lucídio; MACHADO, Ana Maria Neto (Orgs.). A bússola do escrever: desafios e estratégias na orientação de teses e dissertações. Florianópolis/São Paulo: Editora da UFSC/Cortez, 2002

CASTRO, Nyvia Cristina Bandeira de. Exegese de um discurso retrato do orientando précedido pelo retrato do orientador. 1993, 190 p. Tese (Doutorado em Comunicação e Semiótica) - Pontifícia Universidade Católica de São Paulo, 1993.

CORREA, Hamilton Luiz. Fatores relevantes na escolha de um tema de pesquisa. In: Encontro da Associação Nacional dos Programas de Pós-Graduação em Administração, 8., 1984, São Paulo. Anais ... p.157-162, São Paulo: ANPAD, 1984.

COSTA, Bárbara Sampaio. Mestrando à deriva: cadê o orientador? Disponível em $<$ http://www2.uol.com.br/estudantenet/home/net reporter/m 2821.html>. Acesso em $18 / 05 / 2004$.

CRYER, Pat. Professionalizing PHD Supervision: Schemes for the accreditation of supervisors. Disponível em: <http://cdtl.nus.edu.sg/link/nov2000/pgs2.htm.> Acesso em: 10/10/2003.

CUNHA, L. A. Pós-graduação em educação: no ponto de inflexão? Cadernos de Pesquisa. FCC. São Paulo, n. 77, p.63-80, maio 1991. 
CURY, Carlos Roberto Jamil. Pós-graduação: um grande desafio pela frente. Assessoria de comunicação social do Ministério da Educação. Disponível em: <http://www.mec.gov.br> Acesso em : 25 julho 2003.

DA SILVA, José Aparecido da, et al. (Orgs.). Reflexões sobre Universidade, Ciência e Pósgraduação. Ribeirão Preto: Holos, 2001.

DISTRIBUIÇÃO da produção de dissertações por programa de pós-graduação em Contabilidade. Disponível em < http:// www.redecontábil.com.br > . Acesso em 25/02/2004.

DONG, Yu Ren. Non-native graduate student's thesis/dissertations writing in science: selfreports by students and their advisor from two U.S. institutions. English for Specific Purposes. New York, v. 17, n. 4, p. 369-390, 1998.

DUARTE, Rosalia. Pesquisa Qualitativa: reflexões sobre o trabalho de campo. Cadernos de Pesquisa, FCC, São Paulo, n. 115, p.139-154, março/2002.

DURHAM, Eunice Ribeiro. A pós-graduação no Brasil: problemas e perspectivas. Estudos Sobre a pós-graduação. Documento de Trabalho n. 8/96. HUPES, FE/USP. Novembro, 1996.

DURHAM, Eunice Ribeiro; GUSSO, D.A. Pós-graduação no Brasil: problemas e perspectivas. Seminário Internacional sobre tendências da pós-graduação. Brasília: CAPES, 1991.

ECO, Umberto. Como se faz uma tese. 16 ed. São Paulo: Perspectiva, 1998.

EXCELÊNCIA NA CONTABILIDADE. Disponível em < http://www.cfc.org.br>. Acesso em: 13/10/2003.

FERNANDES, A. M. Porque e como avaliar. INFOCAPES Boletim Informativo. Brasília, CAPES, v.1, n. 2, p. 21-23, out/dez.1993.

FERNANDES, Eda Conte et al. Dissertação de mestrado: elementos inibidores e facilitadores. Revista de Administração, São Paulo, v. 28, n. 2, p.103-116, abril/junho 1993.

FERREIRA SOBRINHO, A. A orientação: Multidimensões possíveis. Disponível em $<$ http://astresmetodologias.com.br/modulo6.html>. Acesso em 18/05/2004. 
FERRETTI, Celso João. Acompanhamento do processo de escrever de mestrandos e doutorandos: um depoimento. In: BIANCHETTI, Lucidio (Org.). Trama e texto: leitura crítica, escrita criativa. V. II. Passo Fundo: Plexus Editora, 1997.

FIORIN, José Luiz. A formação do pesquisador: da iniciação científica ao pós-doutorado. In: JANCSÓ, Istvám; CAMPELATO, Maria Helena Rolim, (Orgs.). Humanidades: a pesquisa na avaliação do mérito acadêmico. Seminários de Pesquisa. São Paulo: FFLCH, 1999.

FLICK, Uwe. Uma introdução à pesquisa qualitativa. Traduzido por Sandra Netz. Porto Alegre: Bookman, 2004.

FRAME, Iain A.; ALLEN, Ilis. A flexible approach to PhD research training. Quality Assurance in Education, Londres, v. 10, n. 2, p. 98-103, October 2002.

FREITAS, Henrique R.; ZAWISLAK, Paulo A. Como deve ser, afinal, o desenvolvimento do processo de mestrado em administração? Disponível em <http://read.adm.ufrgs.br/read02/artigo/freitas.html>. Acesso em: 21/10/2003.

FREITAS, Maria Éster de. Viver a tese é preciso! Reflexões sobre aventuras e desventuras da vida acadêmica. Revista de Administração de Empresas, São Paulo, v. 42, n.1, p. 88-93, jan./mar. 2002.

FRIGOTTO, Gaudêncio. Lições do ato de orientar e examinar dissertações ou teses. In: BIANCHETTI, Lucídio. Trama e texto: leitura crítica, escrita criativa. V.II. São Paulo: Plexus, 1997.

GARCIA, Regina Leite; ALVES, Nilda. A necessidade de orientação coletiva nos estudos sobre o cotidiano - duas experiências. In: BIANCHETTI, Lucídio; MACHADO, Ana Maria Neto (Orgs.). A bússola do escrever: desafios e estratégias na orientação de teses e dissertações. Florianópolis/São Paulo: Editora da UFSC/Cortez, 2002.

GIL, Antonio Carlos. Como elaborar projetos de pesquisa. 3 ed. São Paulo: Atlas, 1996.

GODOY, Arilda Schmidt et al. Concepções e expectativas de alunos sobre os programas de mestrado: uma análise a partir da disciplina metodologia do trabalho científico. Administração On Line, São Paulo, V.1, n.2, p. 10-26, abr./jun. 2000.

GOMES, Candido Alberto (Org.). Gestão Educacional: o Brasil no mundo contemporâneo. Em Aberto, INEP/MEC, Brasília, v. 19, n. 75, p. 9-21, julho, 2002. 
GOMES, Mauro Tapias. A redação de teses e dissertações: estudo de aspectos lingüísticos e gramaticais em monografias produzidas entre 1989 e 1993. 1995, 147 p. Tese (Doutorado em Administração) - Escola Superior de Administração de Empresas. Fundação Getúlio Vargas, São Paulo, 1995.

GOODE, Willian J.; HATT, Paul K. Métodos em pesquisa social. São Paulo: Nacional, 1960.

HAGUETTE, Tereza Maria Frota. Universidade: nos bastidores da produção do conhecimento. Revista Brasileira de Estudos Pedagógicos. Brasília, v.75, n.180, p.157-169, jan/dez. 1994.

HENRIQUES, Antonio; MEDEIROS, João Bosco. Monografia no curso de Direito. São Paulo: Atlas, 1999.

HIPÓLITO, Oscar. Mestres para que? Carta Capital, Brasília, 19 de novembro de 2003, p. 44.

INFOCAPES. Disponível em < http:// www.capes.gov.br>. Acesso em 25/02/2004.

KERLINGER, Fred N. Metodologia da pesquisa em ciências sociais: um tratamento conceitual. São Paulo: EPU/EDUSP,1981.

KNIGHT, N.; ZUBER-SKERRITT, O. Problems and methods in research: a course for the beginning research in the Social Sciences. Higher Education Research and Development, Kensington, Austrália, v.5, n.1, 1986.

LEHMAN, Yvette Piha. Aquisição da identidade vocacional em uma sociedade de crise dois argumentos na escolha profissional liberal. 1988, 219 p. Tese (Doutorado em Psicologia) - Instituto de Psicologia. Universidade de São Paulo, 1988.

LEHMANN, Ângela Valéria Levay. Fatores que intermediam as interações entre orientador e orientando durante a dissertação de mestrado: uma abordagem quantitativa. 1999. Dissertação (Mestrado em Educação) - Universidade Católica de Brasília, 1999.

LEHMANN, Ângela Valéria Levay; RODRIGUES JR., José Florêncio. Fatores que intermediam as interações entre orientador e orientando durante a dissertação de mestrado: 
uma abordagem quantitativa. Educação Brasileira, Brasília, v. 23, n. 47, p. 141-154, jul./dez. 2001.

LICHT, René. Relacionamento interpessoal. Apostila para o curso de Capacitação Gerencial do Programa de Educação continuada para executivos do Departamento de Administração da FEA/USP, 1997.

LOUI, Michael C. How to choose a thesis advisor. Disponível em <http://wocket.csl.uiuc.edu./ loui/advisor.html.> Acesso em: 03/11/2003.

LUNA, Sérgio Vasconcelos de. Análise da dificuldade na elaboração de teses e de dissertações a partir da identificação de prováveis contingências que controlam essa atividade. 1983. 261 p. Tese (Doutorado em Psicologia) - Instituto de Psicologia, Universidade de São Paulo, 1983.

MACHADO, Ana Maria Netto. A relação entre a autoria e a orientação no processo de elaboração da teses e dissertações. In: BIANCHETTI, Lucídio; MACHADO, Ana Maria Neto (Orgs.). A bússola do escrever: desafios e estratégias na orientação de teses e dissertações. Florianópolis/São Paulo: Editora da UFSC/Cortez, 2002.

MADSEN, David. Successful dissertation and thesis: a guide to graduate student research from proposal to completion. 2nd. San Francisco.C.A. Jossey Bass, 1992.

MAHER, Brendam A. A pós-graduação nos Estados Unidos: tendências e problemas. Concepções e papel do orientador. NUPES/FE/USP. Documento de trabalho n. 12, 1996, p.10-14.

MARCONI, Marina de Andrade; LAKATOS, Eva Maria. Fundamentos de metodologia científica. 5 ed. São Paulo: Atlas, 2003.

MARONI NETO, Ricardo. Reflexões sobre o processo de construção da monografia pela ótica do orientador. Revista Álvares Penteado, São Paulo, v.5, n.11, p. 95-106, abril 2003.

MARQUES, Mario Osório. A orientação da pesquisa nos programas de pós-graduação. In: BIANCHETTI, Lucídio; MACHADO, Ana Maria Neto. (Orgs.). A bússola do escrever: desafios e estratégias na orientação de teses e dissertações. Florianópolis/São Paulo: Editora da UFSC/Cortez, 2002.

MARTINELLI, Anita Favaro. Pós-graduação no Brasil. Revista Renascença de Ensino e Pesquisa. São Paulo, v.1, n. 2, p. 1-16, jan/jun 2002. 
MARTINS, Carlos Benedito. O ensino superior brasileiro nos anos 90. São Paulo em Perspectiva. São Paulo, v. 14, n. 1, p. 41-60, jan./mar. 2000.

MARTINS, Gilberto de Andrade. A relação orientador x orientando na elaboração de trabalhos técnico científicos. In: Seminários em Administração, 2. São Paulo. Anais... São Paulo: 1997, p.56-64.

Metodologias convencionais e não convencionais e a pesquisa em Administração. Caderno de Pesquisas em Administração. v.0, janeiro/1994ạ, p.04.

Epistemologia da Administração. 1994. 110 p. Tese (Livre docência em Administração) - Faculdade de Economia, Administração e Contabilidade. Universidade de São Paulo, 1994.

MARTINS, Gilberto de Andrade; LINTZ, Alexandre. Guia para elaboração de monografias e trabalhos de conclusão de curso. São Paulo: Atlas, 2000.

MATTAR, Fauze Najib. Pesquisa de marketing. 2. ed. Vol. 2. São Paulo: Atlas, 1996.

MESTRADO E DOUTORADO REQUEREM TEMPO INTEGRAL. Valor Econômico, São Paulo, 22 de outubro de 2003. Caderno Educação Executiva, p. F4.

MINAYO, Maria Cecília de Souza (Org.). Pesquisa Social: Teoria, método e criatividade. 4 ed. Petrópolis: Vozes, 1995.

MINISTÉRIO DA EDUCAÇÃO. Pós-graduação: Enfrentando novos desafios. Documento síntese do seminário nacional. Disponível em: <http://www.mec.gov.br>. Acesso em: 13 julho 2003.

MOREIRA, Daniel Augusto. O método fenomenológico na pesquisa. São Paulo: Pioneira/Thonson, 2002.

MOSES, I. Supervision of higher degree students: problems areas and possible solutions. Higher Education Research and Development, Kensington, Austrália, v.3, n.2, 1984.

OLIVEIRA, Antônio Benedito Silva (Org.). Métodos e técnicas de pesquisa em Contabilidade. São Paulo: Saraiva, 2003. 
OLIVEIRA, Fátima Bayma. Pós-Graduação: Educação e mercado de trabalho. Campinas: Papirus, 1995.

Inovando na pós-graduação, a experiência do MBA da EAESP/FGV. Revista de Administração de empresas. São Paulo, v.36, n.1, p.6-12, jan/mar. 1996

PEREIRA, Rita de Cássia de, et al. Doutorado em Administração no Brasil: um estudo exploratório dos fatores relacionados ao conceito de doutor e das responsabilidades dos principais agentes envolvidos no curso de doutorado. In: Encontro da Associação Nacional dos Programas de Pós-Graduação em Administração, 26., 2002, Salvador. Anais ... Salvador: ANPAD, 2002. CD-ROM.

PICCININ, Sergio J. Graduate students supervision: resources for supervisors \& students. Disponível em < http://www.cdtl.nus.edu.sg/link/nov2000/cover.html.> Acesso em: 22/10/2003.

PINTO, J. M. Análise do comportamento de pesquisar de um estudante de pósgraduação em Psicologia: um estudo de caso. 1980, 190 p. Tese (Doutorado em Psicologia) - Instituto de Psicologia, Universidade de São Paulo, 1980.

PRATES, Maurício. Pós-graduação: Oportunidade de renovação. O Estado de São Paulo, São Paulo, 20 janeiro 1997. p.3.

RAMOS-CERQUEIRA, Ana Teresa de Abreu. A prática pedagógica como processo de comunicação: a relação professor-aluno como eixo do ponto de vista psicológico. Disponível em < http//www.interface.org.br/ed1_d3.htm> Acesso em: 08/10/2003.

REIS, G. A qualidade da formação de doutores e o financiamento de grupos de pesquisa no Brasil: as relações óbvias e as nem tanto. In: PALATNICK et al. (Orgs.). A pós-graduação no Brasil. Rio de Janeiro: UFRJ, 1998.

REIS, Rick. Why students don't complete their dissertations. Stanford University. Disponível em < http://stanford.edu/tomprof/postings.html. > Acesso em: 22/10/2003.

RIBEIRO, Marli. Formação contínua. Valor Econômico, São Paulo, 22 de outubro de 2003. Caderno Educação Executiva, p. F1. 
RICHARDSON, Roberto Jarry. Pesquisa Social: métodos e técnicas. 3 ed. São Paulo: Atlas, 1999.

RODRIGUES JR., José Florêncio et al. A dissertação de mestrado: um estudo sobre as interações entre o orientador e orientando com base em incidentes críticos. Revista Brasileira de Estudos Pedagógicos, Brasília. v. 74, n. 177, p. 437-463, maio/agosto 1993.

RUDD, E. Research into postgraduate education. Higher Education Research and Development, Kensington, Austrália, v.3, n.2, 1984.

SANCHES, S.G. O processo de elaboração de teses e dissertações por orientandos dos programas de estudos pós-graduandos em psicologia social e educação da Pontifícia Universidade Católica de São Paulo. 1992, 147 p. Dissertação (Mestrado em Psicologia) Pontifícia Universidade Católica de São Paulo, 1992.

SANTOS, Andreza Maria. Formação e treinamento de administradores: um estudo sobre a produção de dissertações no curso de mestrado da FACE/UFMG. In: Encontro da Associação Nacional dos Programas de Pós-Graduação em Administração, 21. 1988, Rio de Janeiro. Anais ... Rio de Janeiro: ANPAD, 1988, p.1009-1039.

SANTOS, Iraci dos. A instituição da cientificidade: análise institucional e sócio-poética das relações entre orientadores e orientandos de pesquisa em enfermagem. 1997, 221 p. Tese (Doutorado em Enfermagem) - Programa de pós-graduação em Enfermagem, Universidade Federal do Rio de Janeiro, 1997.

SANTOS FILHO, José Camilo; CARVALHO, Maria Lúcia R. D. Orientação coletiva de mestrado na faculdade de educação da Unicamp. Caderno de Pesquisas, FCC, São Paulo, v. 78, p. 73-79, agosto 1991.

SAUAIA, Carlos Aidar; OLIVEIRA, Adriel Rodrigues de. Percepções dos alunos sobre o programa de pós-graduação em administração da FEA/USP. In: Encontro da Associação Nacional dos Programas de Pós-Graduação em Administração, 18., 1994, Rio de Janeiro. Anais ... Rio de Janeiro: ANPAD, 1994. p.243-259.

SAVIANI, Demerval. A pós-graduação em Educação no Brasil: pensando o problema da orientação. In: BIANCHETTI, Lucídio; MACHADO, Ana Maria Neto (Orgs.). A bússola do escrever: desafios e estratégias na orientação de teses e dissertações. Florianópolis/São Paulo: Editora da UFSC/Cortez, 2002.

SCHWARTZMAN, S. et al. Educação no Brasil numa perspectiva de transformação. NUPES/FE/USP, São Paulo, julho 1993. 
SELLTZ, Clarie et al. Métodos de pesquisa nas relações sociais. Tradução de Dante Moreira Leite. São Paulo: EPU, 1974.

SEVERINO, Antonio Joaquim. Metodologia do trabalho científico. 22. ed., São Paulo: Cortez, 2002.

SILVEIRA, Regina Célia Pagliuchi. Acompanhando o processo de escrever de pósgraduandos: um depoimento. In: BIANCHETTI, Lucídio. Trama e texto: leitura crítica escrita criativa. São Paulo e Passo Fundo: Plexus e EDIUPF, 1997. v.II.

SMITH, Malcolm. Research Methods in Accounting. London: Sage Publications, 2004.

SOUZA, Hulda Cyrelli. Produção textual: ação solitária ou solidária? In: BIANCHETTI, Lucídio.(Org.). Trama e texto: leitura crítica escrita criativa. V.1.São Paulo: Plexus, 1996.

SOUZA, Tânia Maria de. Pressupostos metodológicos e a administração: uma leitura a partir de Pedro Demo. In: Encontro da Associação Nacional dos Programas de Pós-Graduação em Administração, 18, 1994, Rio de Janeiro. Anais ... Rio de Janeiro: ANPAD, 1994, p.186-191.

TRIVIÑOS, A.N.S. Introdução à pesquisa em ciências sociais: a pesquisa qualitativa em educação. São Paulo: Atlas, 1987.

TUNES, Elizabeth. Identificação da natureza e origens das dificuldades dos alunos de pós-graduação para formularem problemas de pesquisas através dos seus relatos verbais. 1981, 122 p. Tese (Doutorado em Psicologia) - Instituto de Psicologia, Universidade de São Paulo, 1981.

VALVERDE, Antônio José Romera. A inteligência do orientador. Revista de Administração de Empresas, São Paulo, v. 41, n. 3, p. 60-63, jul./mar.2002.

VASCONCELLOS, Eduardo P. Gondim de. O problema da produção de teses e dissertações de mestrado na área de Administração: barreiras e soluções. In: Encontro da Associação Nacional dos Programas de Pós-Graduação em Administração, 5. 1981, Rio de Janeiro. Anais... Rio de Janeiro: ANPAD, 1981, p.11-29.

VELHO, Lea. Notas sobre a pós-graduação em Ciências Sociais e Humanidades: por que e em que elas diferem das Ciências Naturais? Disponível em $<$ http://rima.pucsp.br/documentos/texto06.htm> Acesso em: 10/09/2003. 
VELLOSO, Jaques (Org.). Formação no país ou no exterior? Doutores na pós-graduação de excelência. Brasília: Capes/Unesco, 2002.

VELLOSO, Jaques; VELHO, Lea. Mestrandos e doutorandos no país: trajetórias de formação. Brasília: CAPES/MEC, 2001.

VERGARA, Silvia Constant. Projetos e relatórios de pesquisa em Administração. 4 ed. São Paulo: Atlas, 2003.

WARDE, Mirian Jorge. Diário de bordo de uma orientadora de teses. In: BIANCHETTI, Lucidio (Org.). Trama e texto: leitura crítica, escrita criativa. V. II. Passo Fundo: Plexus Editora, 1997.

A produção discente dos programas de pós-graduação em Educação no Brasil (19821991): avaliação e perspectivas. In: Avaliação e perspectivas na área de educação (19821991). Porto Alegre: ANPEd/CNPq, 1993, p.51-81.

ZILBERMANN, Regina. Orientação: a aventura compartilhada. In: BIANCHETTI, Lucídio; MACHADO, Ana Maria Neto. (Orgs.). A bússola do escrever: desafios e estratégias na orientação de teses e dissertações. Florianópolis/São Paulo: Editora da UFSC/Cortez, 2002. 


\section{APÊNDICES}

Apêndice 1 - Roteiro de Entrevistas

109

Apêndice 2 - Descrição das Características dos Sujeitos Entrevistados . 


\section{APÊNDICE 1}

\section{ROTEIRO DE ENTREVISTAS}

\section{ROTEIRO DE ENTREVISTAS PARA OS ORIENTANDOS}

Programa de pós-graduação: Bolsista? Há quanto tempo trabalha com o orientador?

1) Quais os fatores que o levaram a escolher o seu orientador?

2) Quais foram as condições e requisitos considerados pelo seu orientador quando o aceitou?

3) Quais os fatores comportamentais que facilitam a relação orientador-orientando?

4) Quais os fatores comportamentais que dificultam a relação orientador-orientando?

5) Quais os fatores técnicos e de conhecimento que facilitam a relação orientadororientando?

6) Quais os fatores técnicos e de conhecimento que dificultam a relação orientadororientando?

7) Você foi atendido de forma sistemática pelo seu orientador? Fale-me como se deram os encontros.

8) O que você sugeriria para superar obstáculos e dificuldades no processo de relacionamento orientador e orientando?

9) Você diria que a qualidade de uma dissertação ou tese, em muito, depende da orientação recebida? Explique!

10) Você gostaria de acrescentar algo sobre esta problemática?

\section{ROTEIRO DE ENTREVISTAS PARA OS ORIENTADORES}

Tempo de experiência em orientação de teses de mestrado e doutorado:

Regime de trabalho Programa de pós-graduação

Quantos mestres em Contabilidade o sr.(a) já orientou? 
Quantos doutores em Contabilidade o sr.(a) já orientou?

Quantos orientandos o sr.(a) orienta atualmente?

1) Quais são as condições e pré-requisitos que você considera para aceitação de um orientando?

2) Quais os fatores comportamentais que facilitam a relação orientador e orientando?

3) Quais os fatores comportamentais que dificultam a relação orientador e orientando?

4) Quais os fatores técnicos e de conhecimento que facilitam a relação orientador e orientando?

5) Quais os fatores técnicos e de conhecimento que dificultam a relação orientador e orientando?

6) Em que condições se dão os encontros com os orientandos? Qual a freqüência?

7) O que você sugeriria para superar obstáculos e dificuldades no processo de relacionamento orientador e orientando?

8) Você diria que a qualidade de uma dissertação ou tese, em muito depende da orientação recebida? Explique!

9) Gostaria de acrescentar algo a mais sobre esta problemática? 


\section{APÊNDICE 2 \\ DESCRIÇÃO DAS CARACTERÍSTICAS DOS SUJEITOS ENTREVISTADOS}

Orientando 1 - Aluno do programa em Controladoria e Contabilidade da USP, professor de universidade pública, trabalha há um ano e meio com o orientador, não possui bolsa.

Orientando 2 - Aluno do programa em Controladoria e Contabilidade da USP, trabalhou há um ano com o orientador e não possui bolsa, trabalha na iniciativa privada em São Paulo.

Orientando 3 - Aluno do programa em Controladoria e Contabilidade da USP, professor de universidade particular, trabalha há um ano com o orientador, não possui bolsa.

Orientando 4 - Aluna do programa em Controladoria e Contabilidade da USP. Teve bolsa da CAPES durante dois anos, tempo de trabalho com o orientador: um ano e meio.

Orientando 5 - Aluna do programa em Controladoria e Contabilidade da USP, professora de universidade pública, tem bolsa pelo CNPq pelo prazo de dois anos, trabalha com o orientador há um ano.

Orientando 6 - Aluno do programa em Controladoria e Contabilidade da USP, professor de universidade pública, tem bolsa da Capes e está trabalhando com o orientador há um ano e meio.

Orientando 7 - Aluno do mestrado em Ciências Contábeis da PUCSP, professor de universidade pública, trabalha com o orientador há um ano, sem bolsa no mestrado.

Orientando 8 - Mestre em Contabilidade pela PUCSP em 2002, coordenador de curso de uma universidade privada. Trabalhou com o orientador aproximadamente dois anos sem bolsa. 
Orientando 9 - Mestre em Contabilidade pela PUCSP em 2002, doutorando em Contabilidade pela USP, professor da PUC Campinas. Trabalhou com o orientador aproximadamente dois anos. Teve bolsa da Capes.

Orientando 10 - Mestre em Contabilidade pela FECAP em 2002, trabalha na iniciativa privada e em uma universidade pública. Trabalhou um ano com o orientador e fez o mestrado sem bolsa.

Orientando 11- Mestre em Contabilidade pela PUCSP em 2002, coordenador de curso de uma universidade privada. Trabalhou com o orientador aproximadamente dois anos. Teve bolsa da Capes durante dois anos.

Orientando 12 - Mestre em Contabilidade pela USP em 2002. Tempo efetivo de orientação: 10 meses e sem bolsa. Participou de projetos com o orientador desde a sua graduação na USP.

Orientando 13 - Doutor em Controladoria e Contabilidade pela USP em 2002, professora da USP. Trabalhou com o orientador durante cinco anos, não teve bolsa.

Orientando 14 - Aluno do Doutorado em Controladoria e Contabilidade da USP, professor de universidade particular, teve bolsa durante o mestrado, trabalha com o orientador há aproximadamente quatro anos.

Orientando 15 - Aluno do Doutorado programa em Controladoria e Contabilidade da USP, professor de universidade pública, tem bolsa da Capes e está trabalhando com o orientador há quatro anos.

Orientador 1 - Professor do Programa em Controladoria e Contabilidade da USP, regime de trabalho RDIDP, quatro anos de experiência em orientações de dissertações, já orientou quatro mestres e orienta apenas um aluno atualmente. 
Orientador 2 - Professor do Programa em Controladoria e Contabilidade da USP, regime de trabalho RDIDP, seis anos de experiência em orientações de dissertações, já orientou nove mestres e atualmente orienta seis alunos.

Orientador 3 - Professor do programa em Controladoria e Contabilidade Estratégica da FECAP, regime de trabalho RDIDP. Tempo de experiência: 3 anos, já orientou nove mestres em Contabilidade e atualmente orienta seis alunos.

Orientador 4 - Professor do Programa em Ciências Contábeis da PUCSP. Tempo de experiência em orientação: dez anos e regime de trabalho dedicação parcial. Dez mestres orientados e atualmente tem seis orientandos.

Orientador 5 - Professor do Programa em Controladoria e Contabilidade da USP, RDIDP, quatro anos de experiência em orientações de dissertações, já orientou seis mestres e orienta oito alunos atualmente.

Orientador 6 - Professor do programa em Controladoria e Contabilidade Estratégica da FECAP, regime de trabalho parcial. Tempo de experiência em orientação, acima de dez anos, já orientou trinta e cinco mestres em Contabilidade e Administração e atualmente orienta seis alunos.

Orientador 7 - Professor do Programa em Controladoria e Contabilidade da USP, RDIDP, dezesseis anos de experiência em orientações de dissertações e teses, mais de vinte mestres e doutores formados, orienta seis alunos atualmente. 